University of Rhode Island

DigitalCommons@URI

Open Access Dissertations

1994

\title{
Girls' and Boys' Beliefs About Adult Work: Evaluating the Effectiveness of a School-Based Program
}

Deborah M. Dutton

University of Rhode Island

Follow this and additional works at: https://digitalcommons.uri.edu/oa_diss

\section{Recommended Citation}

Dutton, Deborah M., "Girls' and Boys' Beliefs About Adult Work: Evaluating the Effectiveness of a SchoolBased Program" (1994). Open Access Dissertations. Paper 1107.

https://digitalcommons.uri.edu/oa_diss/1107

This Dissertation is brought to you for free and open access by DigitalCommons@URI. It has been accepted for inclusion in Open Access Dissertations by an authorized administrator of DigitalCommons@URI. For more information, please contact digitalcommons-group@uri.edu. 


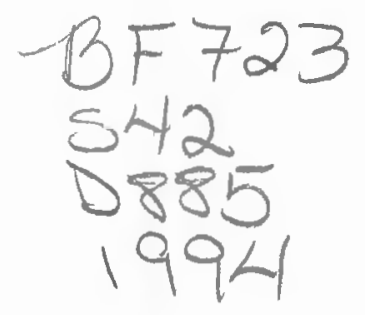

GIRLS' AND BOYS' BELIEFS ABOUT ADULT WORK: EVALUATING THE EFFECTIVENESS OF A SCHOOL-BASED PROGRAM BY DEBORAH M. DUTTON

A DISSERTATION SUBMITTED IN PARTIAL FULFILLMENT OF THE REQUIREMENTS FOR THE DEGREE OF DOCTOR OF PHILOSOPHY IN PSYCHOLOGY

$$
32697069
$$




\section{Abstract}

This project evaluated the effectiveness of a short-term educational intervention program intended to alter sex-role beliefs of children regarding adult careers using a non-equivalent control group design. Participants were second and fifth grade students from a New England elementary school. Dependent measures were The Occupational Choice Survey (OCS), The Stereotypic Occupational Scale (SOS), The Children's SexRole Inventory (CSRI), and The Self-Perception Profile for Children (SPPC). Interventions included reading fictional and nonfictional literature of adults in nontraditional work roles, followed by a guided discussion, and a panel discussion with adults in traditional and nontraditional roles, followed by a guided discussion. The goal of the intervention was to broaden children's gender schemas of "self" and "others," with respect to "careers."

ANCOVA and paired t-test analyses found the intervention to be moderately effective in altering children's beliefs about "others" in nontraditional fields, with intervention participants more likely to accept men in traditionally feminine roles and women in traditionally masculine roles. Second graders were more rigid than fifth graders regarding "self" roles. On the CSRI, boys rated themselves higher on both the $\mathrm{M}$ and $\mathrm{F}$ scales than did girls, hence challenging the validity of the CSRI as a measure of sex-typing in children.

Results of the paired t-tests suggest that the control participants were possibly influenced by the testing procedure. Girls in the intervention group showed more changes in the area of "self" career choices with respect to gender neutral and 
nontraditional jobs than boys. It appears in general that the intervention was somewhat more effective with younger participants and girls.

The qualitative analyses provide support for the proposition that the male role is more highly valued than the female role by both boys and girls. The data suggest that there is more tolerance for girls and little tolerance for boys crossing gender lines in regards to adult work. The reason given for interest in specific careers followed communal and agentic themes.

Girls that expressed an interest in nontraditional jobs gave communal/nurturing reasons for their interest, while stating that boys would be interested in power, status, and monetary gains for that same job. In general, boys expressed interest in athletics, mathematics and science; girls did not.

When scores on the measuring instruments were examined in relation to interview data, there was a wide range of responses on perceived competence and global self-worth measures. Those who chose nontraditional jobs in the interviews did not differ in their self descriptions from those who chose traditional jobs.

Results of this study have implications for theory regarding career development of children. 


\section{Acknowledgements}

First, I would like to express my profound gratitude to Dr. Denise DeZolt for allowing me the privilege of being the first doctoral student in which she has served as major professor, and for her thoughtful criticism, direction, and support. Drs. Bernice Lott and Janet Kulberg have served as intellectual mentors, challenging my thinking and helping me to grow as a feminist scholar and school psychologist. Thank you to Drs. Bea Schultz and George Willis for their thoughtful commentary on this project, and to Dr. Susan Brady for her ongoing guidance and support throughout my tenure at URI. I would like to acknowledge Karen Macari, Nancy Picardi, Karen Rickershauser and Wendy Small for allowing me to conduct this project within their classrooms, Paul Guerrette for his exceptional support as school principal, Priscilla Osterland for administrative support, and to Jean Maloney-Stewart and Pam Girouard, my friends and confidants, for their patience, kindness, encouragement, and tolerance when my nights were short of sleep. Thank you to Sally Rogers and Liz Dillon for their assistance and good humored support, and to Willie Ruzzo and Nancy Picardi for their generous help with coding the data.

I would like to thank my parents Jack and Pat Dutton, my sisters Barbara Ferrara and Patti Conway, and my brother Greg Dutton for their love and support. My brother Greg Dutton provided significant technical assistance in the preparation of my defense and my sister-in-law Lori Dutton provided considerable emotional support. I would also like to acknowledge my father-in-law, David Chiller, for sharing his home with me during the writing process and his interest in my work. One of the best outcomes of my 
URI experience was developing my friendship with Myra Green Gipstein. Thank you for your friendship. I would also like to thank Katharina Decas, my high school coach who instilled confidence in a fragile young girl. Her influence in my life can never be measured - she taught me to have courage to meet the challenges that come my way.

To my step-children Lesley, Matt and Jennie Chiller, thanks for your understanding of the long-hours spent away from the family, and to Lesley, especially, for an exceptional job transcribing the interviews for this project. To Robert Chiller, my husband and friend, thank you for all the nurturance and succor, for your generosity of spirit, for being the consummate mensch, and for insisting I complete that which I had long-ago begun. Your sacrifice during this time has been immeasurable. Thank you and I love you.

To my grandmothers - Suzanna Hall Dutton and Elizabeth Gillis Lydon, hard working, intelligent women who loved me immeasurably; to my Aunt Betty Lydon, who proof-read my early draft during her struggle with cancer - and, moreover, was loving and extremely generous to me; to my Aunt Peggy Lydon Horton who gave my life joy and gladness; and to my mother-in-law, Blossom Chiller, who was an intellectually stimulating and supportive addition to my life - this is dedicated in your memory. 


\section{Table of Contents}

Acknowledgements $\ldots \ldots \ldots \ldots \ldots \ldots \ldots \ldots \ldots$ iv

List of Tables $\ldots \ldots \ldots \ldots \ldots \ldots \ldots \ldots \ldots \ldots \ldots \ldots \ldots \ldots$ viii

Chapter I. Introduction. $\ldots \ldots \ldots \ldots \ldots \ldots \ldots \ldots \ldots \ldots$

Statement of the Problem . . . . . . . . . . . . . . 1

Theoretical Assumptions . . . . . . . . . . . . . . 2

Review of the Literature .................. 5

Research Questions and Hypotheses . . . . . . . . . . 18

Chapter II. Method . . . . . . . . . . . . . . . . 21

Participants ......................... 21

Research Design ..................... 21

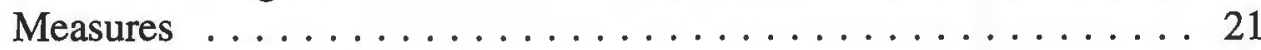

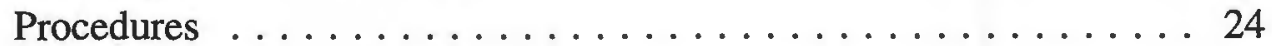

Chapter III. Results . . . . . . . . . . . . . . . . . . . . . . . . . 29

Preliminary Analysis . . . . . . . . . . . . . . 29

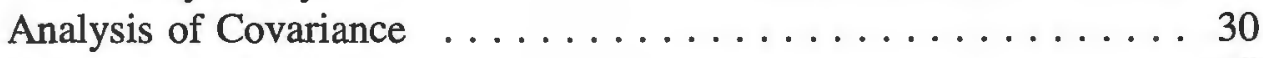

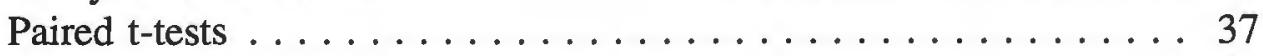

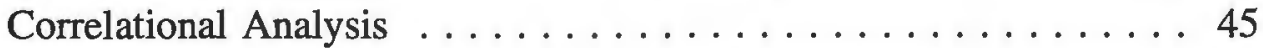

Qualitative Analysis .................. 47

Chapter IV. Discussion $\ldots \ldots \ldots \ldots \ldots \ldots \ldots \ldots \ldots \ldots$

Summary of Findings . . . . . . . . . . . . . . 59

Implications of Results and Limitations of the Research . . . . . . 62

References ..........................66

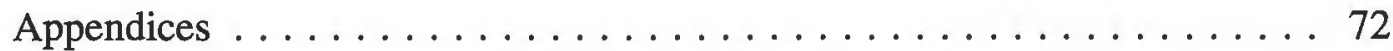

A. Stereotypic Occupational Scale . . . . . . . . 72

B. Children's Sex-Role Inventory . . . . . . . . . . 78

C. Self-Perceived Competence Scale for Children . . . . . . . 79

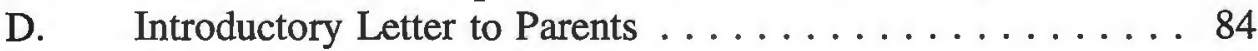

E. Second Letter to Parents $\ldots \ldots \ldots \ldots \ldots \ldots \ldots \ldots$

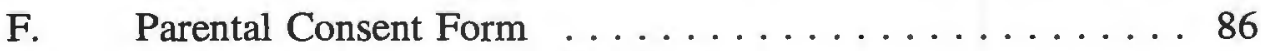

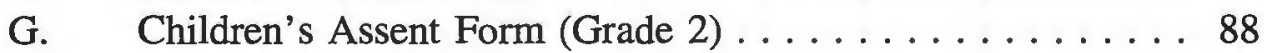

H. Children's Assent Form (Grade 5) . . . . . . . . . . 90 
I. "A Childhood Dream Comes True" . . . . . . . . . . 92

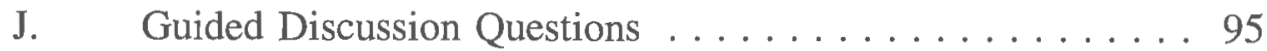

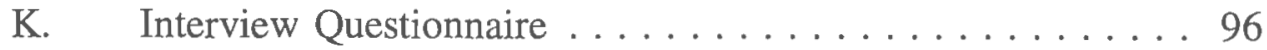

L. List of Careers ................... 97

M. Coding Scheme for Interview Question $1 \ldots \ldots \ldots \ldots 9$

N. Coding Scheme for Interview Question $2 \ldots \ldots \ldots \ldots 99$

O. Coding Scheme for Interview Question $3 \ldots \ldots \ldots . .100$

P. Coding Scheme for Interview Question $4 \ldots \ldots \ldots \ldots 101$

Q. Coding Scheme for Interview Question $5 \ldots \ldots \ldots \ldots$

R. Coding Scheme for Interview Question $6 \ldots \ldots \ldots \ldots$

S. Coding Scheme for Interview Question $7 \ldots \ldots \ldots \ldots . .104$

T. Additional Tables .................. 105

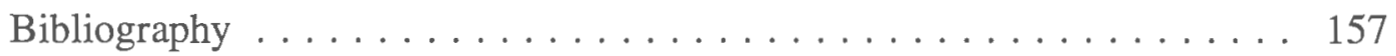


$\underline{\text { Table }}$

\section{List of Tables}

1 Summary of Participants by Gender, Grade and Condition . . . . . 21

2 Means and Standard Deviations for Occupational Choice Survey . . 37

3 Means and Standard Deviations for Stereotypic Occupational

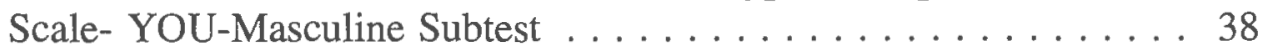

4 Means and Standard Deviations for Stereotypic Occupational

Scale- YOU-Feminine Subtest . . . . . . . . . . . . . . . . . 39

5 Means and Standard Deviations for Stereotypic Occupational

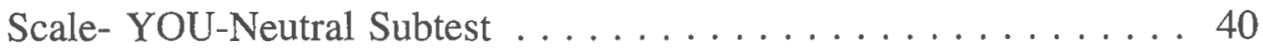

6 Means and Standard Deviations for Stereotypic Occupational

Scale- WOMAN-Masculine Subtest . . . . . . . . . . . . 41

$7 \quad$ Means and Standard Deviations for Perceived Competence

- Scholastic . . . . . . . . . . . . . . . . . . . . . . 42

8 Means and Standard Deviations for Perceived Competence

- Social ... ...................... 43

9 Means and Standard Deviations for Perceived Competence

- Athletic . . . . . . . . . . . . . . . . . . . . . . 43

10 Means and Standard Deviations for Perceived Competence

- Physical . . . . . . . . . . . . . . . . . . . 44

11 Means and Standard Deviations for Perceived Competence

- Behavioral . . . . . . . . . . . . . . . . . . . 45

12 Means and Standard Deviations for Perceived Competence

- Global . . . . . . . . . . . . . . . . . . . . . . . 45

13 Summary of Correlations Between CSRI and YOU-Dutton

Measures at Pre- and Post-test . . . . . . . . . . . . 46

14 Summary Table of Test-Retest Reliability for all Dependent

Measures on Control Group Correlations Between Pre-test and

Post-test $(\mathrm{N}=40)$ 
15 Pretest Equivalence Analysis of Intervention vs Control Condition on Dependent Measures ( $2 \times 2 \times 2)$ ANOVA (Gender x Grade x Intervention) . . . . . . . . . . . . . 106

16 Pretest Equivalence Analysis of Grades 2 vs 5 (ANOVA) on all Dependent Measures ( $2 \times 2 \times 2)$ ANOVA (Gender $x$ Grade $\mathrm{x}$ Intervention) . . . . . . . . . . . . . . . . . . . . . 107

17 Pretest Equivalence Analysis of Gender on all Dependent Measures $(2 \times 2 \times 2)$ ANOVA (Gender x Grade x Intervention) . . 108

18 Means and Standard Deviations and $(\mathrm{N})$ for Children's Perception of Future Occupational Choices for "Self" at Pre-test and Post-test by Grade, Gender, \& Treatment Group . . . 109

19 Means and Standard Deviations and (N) for Children's Perception of Future Occupational Choices in Traditional Stereotypic Masculine Career for "Self" at Pre-test and Post-test by Grade, Gender, $\&$ Treatment Group . . . . . . . . . . . . . . . . . . . 110

20 Means and Standard Deviations and $(\mathrm{N})$ for Children's Perception of Future Occupational Choices for Stereotypic Feminine Careers for "Self" at Pre-test and Post-test by Grade, Gender, \& Treatment Group

21 Means and Standard Deviations and $(\mathrm{N})$ for Children's Perception of Future Careers on Stereotypic Gender Neutral Careers for "Self" at Pre-test and Post-test by Grade, Gender, \& Treatment Group . . 112

22 Means and Standard Deviations and $(\mathrm{N})$ for Children's Perception of Stereotypic Masculine Careers for "Men" at Pre-test and Post-test by Grade, Gender, \& Treatment Group . . . . . . . . . . . 113

23 Means and Standard Deviations and $(\mathrm{N})$ for Children's Perception of "Men" in Stereotypic Feminine Careers at Pre-test and Post-test by Grade, Gender, \& Treatment Group . . . . . . . . . . 114

24 Means and Standard Deviations and $(\mathrm{N})$ for Children's Perception of "Men" in Stereotypic Gender Neutral Careers at Pre-test and Post-test by Grade, Gender, \& Treatment Group . . . . . . . . . 115 
25 Means and Standard Deviations and (N) for Children's Perception of "Women" in Stereotypic Masculine Careers at Pre-test and Post-test by Grade, Gender, \& Treatment Group . . . . . . . . . . 116

26 Means and Standard Deviations and $(\mathrm{N})$ for Children's Perceptions of "Women" in Stereotypic Feminine Careers at Pre-test and Post-test by Grade, Gender, \& Treatment Group by Grade, Gender, $\&$ Treatment Group . . . . . . . . . . . . . . . 117

27 Means and Standard Deviations and (N) for Children's Perception of "Women" in Stereotypic Gender Neutral Careers at Pre-test and Post-test by Grade, Gender, \& Treatment Group . . . . . . . . . 118

28 Means and Standard Deviations and (N) for CSRI-Masculine by Grade, Gender, \& Treatment Group . . . . . . . . . . . . . . . . . . 119

29 Means and Standard Deviations and $(\mathrm{N})$ for CSRI-Feminine by Grade, Gender, \& Treatment Group . . . . . . . . . . . . . . 120

30 Means and Standard Deviations and $(\mathrm{N})$ for Perceived Competence Scholastic by Grade, Gender, \& Treatment Group . . . . . . . . 121

31 Means and Standard Deviations and (N) for Perceived Competence - Social by Grade, Gender, \& Treatment Group ... . . . . . . 122

32 Means and Standard Deviations and $(\mathrm{N})$ for Perceived Competence - Athletic by Grade, Gender, \& Treatment Group . . . . . . . . . 123

33 Means and Standard Deviations and $(\mathrm{N})$ for Perceived Competence - Physical by Grade, Gender, \& Treatment Group . . . . . . . . . 124

34 Means and Standard Deviations and $(\mathrm{N})$ for Perceived Competence - Behavior by Grade, Gender, \& Treatment Group . . . . . . . . 125

35 Means and Standard Deviations and $(\mathrm{N})$ for Perceived Competence - Global by Grade, Gender, \& Treatment.Group . . . . . . . . . . 126

36 Summary Table of $(2 \times 2 \times 2)$ ANOVA (Gender $\times$ Grade $\times$ Intervention) for Occupational Choice Survey (OCS) $\ldots \ldots \ldots \ldots \ldots \ldots 127$ 
37 Summary of $(2 \times 2 \times 2)$ Analysis of Covariance (Gender $\times$ Grade $\mathrm{x}$ Intervention) for Pre-test Covariate Scores . . . . . . . . 128

38 Means and Standard Deviations for Total Sample for Stereotypic Occupational Scale- (SOS) at Pre-test and Post-test . . . . . . . . 129

39 Summary of Main Effects for Dutton Measures-ANCOVA at Post-test with Pre-test as Covariate . . . . . . . . . . . . . . . . . . 130

40 Summary of Interactions for Dutton Measures- (2x $2 \times 2)$ Analysis of Covariance (Gender $\mathrm{x}$ Grade $\mathrm{x}$ Intervention) at Post-test with Pre-test as Covariate . . . . . . . . . . . . . . . . . . 131

41 Summary Table of $(2 \times 2 \times 2)$ Analysis of Covariance (Gender $x$ Grade $x$ Intervention) for Three Subscales of the Dutton - "You" Scale . . . . . . . . . . . . . . . . . . . 132

42 Summary Table of $(2 \times 2 \times 2)$ Analysis of Covariance (Gender $x$ Grade $x$ Intervention) for Three Subscales of the Dutton- "Man" Scale . . . . . . . . . . . . . . . . . . . 133

43 Summary Table of $(2 \times 2 \times 2)$ Analysis of Covariance (Gender $x$ Grade $x$ Intervention) for Three Subscales of the Dutton- "Woman" Scale . . . . . . . . . . . . . . . . 134

44 Summary Table of $(2 \times 2 \times 2)$ Analysis of Covariance (Gender x Grade x Intervention) for Two Subscales of the CSRI Scale . . . . . . . . . . . . . . . . . 135

45 Summary of Pre-test Covariate Score for $2 \times 2 \times 2$ (Gender x Grade x Treatment Group) Analysis of Variance for the Perceived Competence Scale

46 Summary Table of $(2 \times 2 \times 2)$ Analysis of Covariance (Gender $\mathrm{x}$ Grade $\mathrm{x}$ Intervention) for Three Subscales of the Self Perception Scale for Children . . . . . . . . . . 137

47 Summary Table of $(2 \times 2 \times 2)$ Analysis of Covariance (Gender $x$ Grade $x$ Intervention) for Three Subscales of the Harter Self Perception Scale 
$\underline{\text { Table }}$

48 Summary of Paired t-test Results for Occupational

Choice Survey . . . . . . . . . . . . . . . . . . . . . . . . 139

49 Summary of Paired t-test Results for Stereotypic Occupational

Scale (SOS) for You - Masculine . . . . . . . . . . . . . 140

50 Summary of Paired t-test Results for Stereotypic Occupational

Scale (SOS) for You - Feminine . . . . . . . . . . . . . 141

51 Summary of Paired t-test Results for Stereotypic Occupational

Scale (SOS) for You - Neutral . . . . . . . . . . . . . . . . 142

52 Summary of Paired t-test Results for Stereotypic Occupational

Scale (SOS) for Man - Masculine . . . . . . . . . . . . . . 143

53 Summary of Paired t-test Results for Stereotypic Occupational

Scale (SOS) for Man - Feminine . . . . . . . . . . . . . . . 144

54 Summary of Paired t-test Results for Stereotypic Occupational

Scale (SOS) for Man - Neutral . . . . . . . . . . . . . . 145

55 Summary of Paired t-test Results for Stereotypic Occupational

Scale (SOS) for Woman - Masculine . . . . . . . . . . . . 146

56 Summary of Paired t-test Results for Stereotypic Occupational

Scale (SOS) for Woman - Feminine . . . . . . . . . . . . . 147

57 Summary of Paired t-test Results for Stereotypic Occupational

Scale (SOS) for Woman - Neutral . . . . . . . . . . . . . 148

58 Summary of Paired t-test Results for CSRI - Masculine . . . . . . 149

59 Summary of Paired t-test Results for CSRI - Feminine . . . . . 150

60 Summary of Paired t-test Results for Perceived Competence

- Scholastic . . . . . . . . . . . . . . . . . . . . 151

61 Summary of Paired t-test Results for Perceived Competence

- Social . . . . . . . . . . . . . . . . . . . . 152

62 Summary of Paired t-test Results for Perceived Competence

- Athletic . . . . . . . . . . . . . . . . . . . . . . 153 
63 Summary of Paired t-test Results for Perceived Competence

- Physical . . . . . . . . . . . . . . . . . . . . . . . 154

64 Summary of Paired t-test Results for Perceived Competence

- Behavioral .......................... 155

65 Summary of Paired t-test Results for Perceived Competence

- Global . . . . . . . . . . . . . . . . . . . . . . 156 


\section{Chapter I}

\section{Introduction}

\section{$\underline{\text { Statement of the Problem }}$}

This project was designed to investigate whether children's gender-role schemas regarding adult careers (i.e., traditional and nontraditional) can be modified through a curriculum intervention. There is some evidence which suggests that children's gender role schemas are related to future career role preparation. This topic is an important one, as current research suggests that girls have been "short-changed" in the educational process (AAUW Report, 1992; Campbell, 1993) and, as a result, are less prepared than boys for future careers, particularly in the areas of mathematics and science.

Although there has been an increase in women attending college and graduate school, there are significantly fewer women enrolled in the traditionally male-dominated fields. Of those who major in nontraditional areas, few are ever employed in that field. Most of the higher paying careers are still considered more appropriate for men (e.g., in law, judicature, politics, mathematics, biological sciences, space exploration, architecture, engineering, as a physician, dentist, college teacher, protective service worker, computer analyst, management personnel in business, heavy industrial worker, as a worker in manufacturing and the skilled trades) although significant numbers of women are currently working in some of these fields (Wright \& Dwyer, 1990). In addition, the U.S. Census and Labor Report (1991) states that women are still earning $40 \%$ less than men.

Few studies have examined how school-based experiences impact young boys in their job or career choices or interests. There is some evidence to suggest that boys 
as well as girls have been limited in their vocational selections. Furthermore, there is evidence suggesting that traditional "masculine" stereotypic jobs may produce a high level of stress for some men who would prefer to be in other fields (Tozzo \& Golub, 1990).

Research indicates that children's gender-related perceptions and beliefs about adult careers can be modified through school-based interventions, but that such changes are generally about the acceptability of "others" working in a nontraditional field, not the "self" (Bailey \& Nihlen, 1990). The goal of the present study is to explore ways in which "self" perceptions about nontraditional roles can be altered.

The research question under investigation focuses on whether changes in girls' and boys' perceptions toward careers could be achieved in the domain of acceptability for "self" as a result of a short-term classroom intervention at the elementary school level. Program evaluation focused on changes in beliefs, not acquired knowledge or behavioral modifications. The relationship between perceived competence (i.e., scholastic, athletic, social, behavioral, physical, and global self-esteem) and level of career/job stereotyping was also assessed. The children were interviewed subsequent to the collection of data on standardized instruments to further explore gender schema themes through a qualitative analysis.

This study has been guided by a set of assumptions that will now be presented. $\underline{\text { Assumptions }}$

a. This study is based on the assumption that children's sex-role beliefs are influenced by two major factors: cognitive development and social learning or enculturation. It is assumed that gender-roles are learned and that the salience of stereotypical roles are due to strong and prevalent 
cultural beliefs and practices about gender differences rather than to any biologically-based predispositions of the sexes, and that children have an innate tendency to cognitively organize "like" information to make sense of their social worlds.

b. In agreement with Boldizar (1991), it is assumed "that (a) there exist heterogeneous clusters of...attributes that have been culturally defined as more appropriate and desirable for one sex than for the other and (b) there are individual differences in the propensity to use these categories as ideal standards of masculinity and femininity in the self-evaluation of personality and behavior" (p.505-506).

c. As a result, it is believed that individual differences in behavior " do not depend upon sex, but upon acquired attitudes, expectations, sanctions, opportunities for practice and situational demands" (Lott, 1990). Since sex roles are learned, they can be modified.

d. Culturally defined sex-role beliefs and behaviors have already been learned by early elementary school years and children are able to discriminate between gender stereotypic-appropriate and non-appropriate behaviors (Huston, 1983).

e. It is assumed that children between the ages of seven and twelve years of age are at a "prime" age cognitively and socially to benefit from new experiences relevant to sex-roles (Tozzo \& Golub, 1990).

\section{Definition of Terms}

The following is a list of constructs referenced and/or used in this study.

Operational definitions of those constructs being measured are found in Chapter II.

$\underline{\text { Sex }}$ - a biologically - based division or grouping of people (and other animals) into two categories of male and female, determined by reproductive capacity.

Gender - societal roles assigned to males and females; a cultural construction. Gender Roles/Sex-Roles - the culturally prescribed ways in which girls and boys, women and men, are expected to behave. 
Schema - a set of ideas, or a network of associations, that help individuals organize new information.

Gender Schematas - cognitive structures that organize an individual's genderrelated knowledge, beliefs, perceptions, preferences and self-concept; a mechanism by which stereotypic views of men and women are acquired and maintained, as well as the extent to which the knowledge is used to process information to guide behavior.

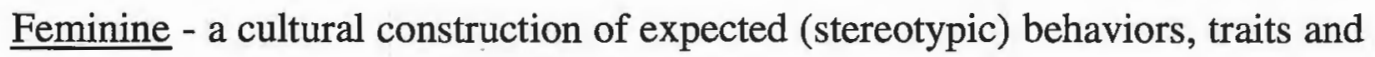
interests assumed appropriate for girls and women generally centering on communality and expressiveness (e.g., desire to be with others, and concern about the welfare of others).

Masculine - a cultural construction of expected (stereotypic) behaviors, traits and interests assumed appropriate for boys and men centering on agency and autonomy (e.g., assertiveness, independence).

Gender Stereotypes - widely-held, early-learned, and socially-validated beliefs about male and female attributes.

Sex-typing/Gender-typing - "the process through which the developing child comes to match the template of preferences, skills, personality attributes, behaviors, and self- concepts prescribed by the culture as appropriate for his or her sex. It is the process through which a culture transforms male and female children into masculine and feminine adults" (Bem, 1987, p. 251). 
Traditional Adult Careers - careers in which over two-thirds of those employed are either women or men.

Non-Traditional Adult Careers - careers in which less than one-third of those employed are either women or men.

Perceived Competence - beliefs about one's competence across the domains of scholastic ability (relative to school work), athletic ability (physical skill in sports or games), social acceptance (peer popularity), behavioral conduct (behaving as one thinks one should) and physical appearance (how one looks). Global Self Esteem - judgment of overall worth as a person, how much one likes oneself.

\section{$\underline{\text { Literature Review }}$}

Theories of sex-role development and perceived competence will now be reviewed, as will the intervention studies designed to alter children's sex-role beliefs about nontraditional jobs.

Theories of Sex-Role Development

Sex-role development begins at an early age and children are poignantly aware of cultural expectations related to sex-appropriate or inappropriate behavior (Bem, 1984). Cultural explanations emphasize that members of social groups acquire common beliefs and values through the processes of childhood socialization and throughout life. Studies of gender stereotypes have demonstrated that a majority of the beliefs that people have about the characteristics of women and men or girls and boys fall into two major 
categories: that boys and men are generally agentic (i.e., assertive, controlling, autonomous) which defines "masculinity," and that girls and women are communal (i.e., desiring to be with others, concerned about the welfare of others, expressive) which defines "femininity." It has been argued that these dimensions have resulted from the functional division of labor in most societies and not from biological predispositions (c.f., Eagly, 1987).

One of the major questions in the sex-role literature is that of how society transforms male and female children into masculine and feminine adults. Four major psychological theories have attempted to explain this process: psychoanalytic, social learning, cognitive-developmental and gender schema theories. Psychoanalytic theory, posits that sex-typing begins with an identification with the same-sex parent through the discovery of genitals, penis envy, castration anxiety and the resolution of the Oedipus Conflict. This theory has received little empirical support in explaining gender-related beliefs and behaviors (See Jacklin, 1989; Bem, 1984; for review). In fact, some researchers have found both boys and girls to be more similar to their mothers than to their fathers, presumably related to the greater time spent with mothers (Stangor \& Ruble, 1987). Social learning, cognitive developmental and gender schema theories have guided the formulation of the present research and therefore are given more attention in this review.

Social Learning Theory. This theory, rooted in the tradition of behaviorism, describes the learning of gender-related behaviors as parallel to the learning of any other behaviors. Behavioral patterns are learned through reinforcement and/or punishment. 
Mischel (1966) and Bandura and Walters (1963), associated with this position, argued that boys and girls receive disparate treatment throughout life, experiencing different rewards and punishment for different behaviors from their parents and others. Researchers have found that gender-identity begins with the observation and imitation of the same-sex parent (Unger \& Crawford, 1992). The child begins to identify with the same-sex parent (usually), copying whole patterns of behavior without specific reinforcement or training. That is, parents' behaviors may be unintentional, yet powerful models for a child's behavior. Behavior becomes sex-typed as a result of imitation (Mussen, 1969) of same-sex models (parents, peers, other adults, television characters, storybook characters). Behavioral patterns are learned though punishment and reinforcement (including attention and/or approval from adults), as well as through observation and imitation of other's behavior through vicarious learning (Bussey \& Bandura, 1984), and through the extinction of sex-inappropriate behavior. Lott and Lott $(1968,1985)$ found that children are more likely to imitate a likable model, one who is associated with positive consequences and less likely to imitate a model associated with unpleasant experiences. Reinforcement and punishment need not be direct or obvious; it may be by means of specific language use (e.g., "good girl").

Another important variable stressed by social learning theorists is that environmental conditions for children are set up in such a way that certain behaviors are more likely to result than others (Jacklin, 1989; Lott \& Maluso, 1993). For example, when girls are given dolls to play with, while boys are given a set of tools, these 
materials not only reinforce gender role expectations, but also increase the likelihood for specific skills to develop as a result of the opportunity to practice them.

Feminist social psychologists emphasize that behavior must be examined in its context, that situational variables must not be overlooked and that antecedents and consequences for specific behavior in specific situations must be studied (Lott, 1985). Women and men show remarkable behavioral diversity across situations that require non-stereotypic responses. A woman may repair the plumbing in her home when she cannot afford to hire a plumber, and a man may calm and sooth his children when they have been frightened. In the same situation, women and men have been found to be more alike than different. In addition, there is significant variation of behavior within each gender. Feminist social learning theorists also emphasize the status and power embedded in our social system (Lott, 1993; Bohan, 1993) which maintains women and men in different positions throughout their lifespan across socioeconomic classes and ethnic groups.

Even in conditions where adults treat young children similarly or say that they do, children still show a great deal of stereotypic knowledge and behavior (Jacklin, 1989), and response to reinforcement appears to be somewhat selective under specific conditions. Bussey and Bandura (1984) found that while children imitate the behavior of a same-sex adult, they are less likely to do so when the adult is doing something different from other same-sex adults. In a study with nursery school children, Fagot (1985a, 1985b) found that girls responded to reinforcement from female teachers and other girls, but not from boys, whereas boys responded to reinforcement from other 
boys, but not from female teachers or girls. Eisenberg, Wolchik, Hernandez and Pasternack (1985), in a study looking at the effects of parental reinforcement, found that children's behavior was not linked to parent's positive reinforcement of specific play choices but to parent's own play choices. Thus, reinforcement appears to be related to the child's cognitive processing.

Cognitive Developmental Theory. Kohlberg (1966) and others (e.g., Bem, 1984) suggest that social learning theory does not offer a complete explanation of gender learning and that rewards for conforming to sex-appropriate behavior do not adequately explain the process of sex-typing.

Cognitive developmental theory views children as active processors of information with an innate tendency to organize and categorize "like" information in order to make sense of their social world (Kohlberg, 1966). Following Piaget's stage theories, Kohlberg proposes that children progress through a series of predictable, qualitatively different stages of cognitive development. For example, younger children (approximately 3-4) are aware of their gender (e.g., "I am a girl") but believe that gender can be changed with trivial alterations such as clothing. This assumption has been empirically challenged and found not to be supported by research. By 6-7 years of age, due to cognitive change or the maturational process, almost all children are aware of the constancy of gender. Cognitive theorists suggest that once children reach this stage of development, they strive to match the cultural expectations of their sex, eventually coming to value the behaviors, interests, and objects that are consistent with their gender label. Consequently, girls begin to do "girl things" (e.g., playing with dolls) 
and boys begin to do "boy things" (e.g., sports). Research indicates that children behave in this way even earlier, but Maccoby (1990) suggests that at ages 6 and 7 children begin to exaggerate gender roles in order to keep conceptual categories distinct. Even when children visit doctors who are women, they still tend to state that doctors are male.

Cognitive developmental theory views the child as an active processor of culturally transmitted information. Motivation for sex-appropriate behavior is based on an innate tendency to categorize similar and dissimilar information. Gender identification begins with a global model and with the same-sex parent as a specific model.

Cognitive developmental theorists contend that social/environmental influences are mediated and regulated by cognitive change (Bigler \& Liben, 1992; Martin \& Halverson, 1981; Martin, Wood, \& Little, 1990; Stangor \& Ruble, 1987). Researchers have examined how the ability to classify is related to the issue of stereotyping (Liben \& Bigler, 1987) and have suggested that these skills influence the ability to process and recall counter-stereotypical information (e.g., a female engineer, a male nurse). In general, past research indicates that children are able to recall gender-stereotypic information better than counter-stereotypic information (Bigler \& Liben, 1990; Martin \& Halverson, 1983), and that children with more advanced classification systems are less likely than those with less-well developed skills to hold rigidly to stereotypes (Leahy \& Shirk, 1984).

Gender Schema Theory. In our society the male role is more valued than the female role in terms of economic and occupational status (Eagly \& Wood, 1982; Deaux, 
Kite, \& Lewis, 1985; Lott, 1993). Whereas cognitive developmental theory does not adequately deal with the influence of a patriarchal society (Unger \& Crawford, 1992), while Gender Schema Theory attempts to explain why gender is such a salient and ubiquitous cognitive construct, despite other possible categorizations. Issues of power and how a patriarchal society reinforces the typical categorization of schema are addressed.

Gender Schema Theory of sex-role development (Bem, 1981b, 1983) contains elements of both social learning and cognitive developmental theories. In genderschematic processing, the child learns about society's definition of maleness and femaleness in terms of content specific information (i.e., anatomy, reproductive function, division of labor, personality attributes) and a heterogeneous network of sex-related associations. Gender differences are not merely strengthened or regulated by external forces, but rather an individual brings to each situation gender-related beliefs that influence perceptions (Bem, 1984).

A schema "is a cognitive structure, a network of associations that organizes and guides an individual's perceptions...functions as an anticipatory structure, a readiness to search for and assimilate incoming information in schema-relevant terms" (Bem, 1984, p. 187). It is a highly discriminating mechanism, imposing structure and meaning onto new stimuli, highly associative (i.e., melding new and old information), as well as sorting and categorizing on the basis of a specific dimension (i.e., gender) in spite of other available dimensions. 
Bem proposes that "...sex-typing derives in large measures from genderschematic processing, from a generalized readiness on the part of the child to encode and organize information - including information about the self - according to the cultures's definition of maleness and femaleness" (Bem, 1984, p. 186). The process is mediated by the child's cognitive processing originating from the sex-differentiation within the community at large. Therefore, sex-typing "...is the process through which the developing child comes to match the template of preferences, skills, personality attributes, behaviors, and self-concepts prescribed by the culture as appropriate for his or her sex. It is the process through which a culture transforms male and female children into masculine and feminine adults" (Bem, 1987, p. 251).

Although recognizing that there are individual differences in the degree to which gender is salient in the processing of information, Bem has suggested that our society encourages gender-typing (i.e., gender schemas). Those who do not conceptualize their worlds in terms of traditional masculine and feminine roles, who transcend gender schematic thinking and are flexible in their beliefs about sex-roles, are considered gender aschematic. Empirical studies have provided some evidence that those who are themselves sex-typed engage in spontaneous gender schematic processing to a greater extent than others and that those engaging in a high degree of gender-schematic processing exhibit a greater amount of stereotypic behavior (Bem, 1984). Bem (1985) posits that this tendency to use gender as a primary schema is closely linked to the selfconcept. 
Whereas cognitive developmental theory proposes that becoming gender-typed is inevitable in the maturation process, Gender Schema Theory suggests that children become gender-typed because adults teach children to differentiate the world in terms of gender from early childhood, with "pinks" and "blues," toy choices, accepted behaviors, adjective descriptions, differential treatment in schools, etc.

The significance of gender schemata in gender role development (Hudak, 1993; Levy \& Carter, 1989; Liben \& Signorella, 1980) and the proclivity to be more or less gender schematic during childhood (Liben \& Signorella, 1980) has been supported by some research.

There is controversy concerning the constructs of femininity and masculinity (Hudak, 1993; Lott, 1993; Unger \& Crawford, 1993) despite the general agreement that society as a whole recognizes and reinforces differential experiences for women and men. Constantinople (1973) challenged the bipolar definition of masculinity and femininity and Bem (1984) conceptualized masculinity and femininity as fully independent constructs defined by cultural associations. Some argue (Helmreich, Spence, \& Holahan, 1979; Pedhauzer \& Tetenbaum, 1979; Spence, 1985; Spence \& Helmreich, 1986) that the current measures used to assess masculinity and femininity are really measuring instrumental and expressive constructs, whereas others (Lott, 1986) assert that the labeling of behavior as masculine or feminine ignores the essential humanness of all behavior and perpetuates gender stereotypes.

In the U.S. work force women are found predominantly in the service fields (e.g., elementary school teachers, nurses, home-health care workers, clerical workers) and men 
in the more physical and powerful roles (e.g., construction, politics, top level administration, manufacturing). Gender Schema Theory suggests that these roles are learned and that schools, as well as other social institutions, shape children in terms of skill development, opportunities and beliefs. According to Gender Schema Theory, the self-concept itself (i.e., ideas, values and feelings about the self) is integrated with the gender schema. Children learn which attributes are to be associated with their own sex and generalize these to themselves.

Perceived Competence/Self-Esteem. The concept of competence is generally related to a specific context (e.g., competence for a particular task or set of tasks), and self-esteem is typically used more globally. Definitions of self-esteem range from the value one places on oneself and one's behavior to feeling proud of oneself for some accomplishment or attributes. Scales have generally treated self-esteem as a unitary concept (Hattie, 1992). Piers and Harris (1964) have assessed academic and nonacademic esteem separately and Coopersmith (1967) measured self-esteem in terms of academic and family/personal dimensions. It was previously believed that self-concept beliefs, including self-esteem, were relatively stable and consistent aspects of personality,without giving much thought to the possible situational factors that may mediate or change one's self-image.

Global self-esteem is the extent to which one "likes oneself as a person, is happy the way one is leading one's life, and is generally happy with the way one is" (Harter, 1985, p. 6). Harter has conceptualized perceived competence or self-esteem in terms of five specific domains: scholastic competence, social acceptance, athletic competence, 
physical appearance and behavioral conduct. The sixth subscale is global self-worth, measuring global perception of general worth as a person.

Early theories of sex-role development assumed that establishing a sex-typed identification with the same sex (e.g., conforming to stereotypically traditional behavior) represented a milestone in the development of healthy self-esteem (Erikson, 1950; Kohlberg, 1966; Mussen, 1969). Subsequent research has seriously questioned this position. In fact, a majority of studies using sex-role inventories have isolated agentic attributes as the best predictors of high self-esteem in both genders (Alpert-Gillis \& Connell, 1989; Bem, 1977; Hall \& Halberstadt, 1980; Lamke, 1982; Spence \& Helmreich 1978). Some have pointed out that the self-esteem measures themselves are loaded with agentic items, and that subscribing to them is the standard for high selfesteem (Huston, 1983). Feminist theorists (e.g., Bem, 1974; Spence \& Helmreich, 1978) argue that the consequences of traditional gender roles for women/girls are dysfunctional. Stereotypic feminine traits have been found to be associated with low self-esteem, anxiety, need for social acceptance and traditional career choices leading to lower status, financial reward and prestige (Klein, 1992). Similarly, Liben and Bigler (1987) report that there have been negative consequences for men and boys for following traditional masculine roles including difficulty in adjusting to school as well as in self-expression and interpersonal skills.

Hughes, Martinek and Fitzgerald (1985) compared self-esteem and nontraditional career choices in girls and boys in grades 3-6. They predicted that higher self-esteem in girls would be correlated with interest in non-traditional roles, whereas higher self- 
esteem in boys would be related to interest in traditional roles because children with high-self esteem would seek out roles that are socially and financially rewarded. Among girls, they found a strong correlation between nontraditional career choices and global self-esteem as well as four components of self-esteem (i.e., self-liking, competence, assertiveness, independence). Among the boys, traditional gender-related perceptions correlated only with self-liking. High self-esteem for boys was strongly correlated with their belief that women should be in traditional jobs and occupy lower positions. The children in this study came from middle to upper-middle class European-American intact families with professional parents. Tozzo and Golub (1990) suggest that boys' higher self-esteem at a younger age may be related to society's greater valuation of stereotypic masculine characteristics.

There is substantial evidence in the adult developmental literature for agentic attributes to predict mental health as measured by life satisfaction measures (Orlofsky, \& O'Heron, 1987; Pietromonaco, Manis, \& Frohardt-Lane, 1986; Whitely, 1985). It therefore behooves educators to rethink messages that are being sent to young girls, in particular, regarding academic and behavioral dimensions of development. As microcosms of society, schools send girls and boys subtle and direct messages about behaviors appropriate for their gender. These messages are likely to have significant long-term effects, including effects on occupational choice.

Intervention Studies. Some researchers have attempted to modify occupational sex-role stereotypes of children through experience with adult nontraditional workers and other interventions. Nihlen and Bailey (1988) were interested in studying children's 
processing of information about non-traditional workers who were introduced to them in their classroom. The questions that the children asked the presenters were evaluated in terms of gender-related categories. It was found that the children encoded cultural messages about careers based on maleness and femaleness. Pre- and Post-tests regarding children's desired occupations were conducted to measure changes in perceptions. Though the children evaluated and assimilated new information regarding the acceptability of nontraditional roles for others, they were resistant to changing evaluations of occupations in terms of the "self" due to fear of social rejection (e.g., being teased).

In a follow-up study, Bailey and Nihlen (1990) focused on evaluating children's perceptions of gender stereotyped adult careers, which resulted in the development of a test to be employed with children (The Ban Gender Stick Figure Test). The rationale for developing such a test was to provide a measure that addressed children's rather than adults' standards regarding stereotypic jobs. In this second study, they also assessed the effects of experience with nontraditional workers on psychological and social dimensions of occupational sex-role stereotyping by elementary school children. Their sample group was $63 \%$ Latin American and 37\% European-American. Results of the study indicated that older children were less sex-typed than younger. Changes regarding stereotypes (e.g., it is okay for Johnny to be a nurse), but not in self choices (e.g., it is not okay for me, Sam, to be a nurse) were noted. In addition they found no significant difference between the magnitude change for boys and girls. 
Intervention studies attempting to alter gender-related perceptions of children regarding possible career selections have primarily used role modeling with adult workers in nontraditional fields. Other types of interventions found effective in altering other kinds of perceptions, such as bibliotherapy, interactive discussion groups and imagining the roles of others, have not previously been used to alter gender stereotypes or gender-related choices.

In other areas of prevention research (e.g., drug and alcohol prevention studies), the literature suggests (see Nastasi \& DeZolt, 1994 for review) that the most effective programs in altering attitudes (i.e., beliefs, norms, self-efficacy) were voluntary programs of a longer duration, where students are actively involved in discussion groups or activities. Cognitive change may be found with a short-term intervention program, however, the effects may not persist or generalize. The present study tests the effectiveness of a multi-method intervention approach.

\section{$\underline{\text { Research Goals and Hypotheses }}$}

The literature suggests that intervention at the elementary school level is effective in changing children's beliefs about sex-roles. If gender schemas are networks of association regarding gender knowledge, perceptions, beliefs, and self-concept then it follows that it is possible for these schema to be altered through the assimilation and accommodation of new concepts. If older children are more flexible in their gender schematic thinking, they may benefit more from a classroom-based intervention than younger children. Finally, if the male role is more highly valued in society as many suggest (Calvert \& Huston, 1987; Hudak, 1993; Lott, 1993; Taylor \& Hall, 1982), it 
follows that young boys will be less-motivated to change their gender concept of others and self and that girls will be more motivated to alter their gender-related? This study tests the general hypothesis that sex-role stereotypes can be altered through treatment intervention, and that girls benefit more than boys from direct intervention. It is also hypothesized that due to cognitive developmental levels, younger children (2nd graders) are less open to change than older children (5th graders).

The first research question asked in this study was: What is the effect of a shortterm educational intervention on children's beliefs about jobs for women and men? It was predicted that, regardless of gender or grade, there would be a significant difference between intervention and control participants at post-test in terms of their beliefs about their own future non-stereotypic employment. Girls in the intervention group at posttest were expected to have more positive attitudes toward non-stereotypic employment than boys in the intervention group, and fifth graders in the intervention group were expected to have more positive attitudes than second grades. It was also predicted that regardless of gender or grade level, there would be a significant difference between intervention and control participants at post-test in terms of beliefs about traditional job options for men and women generally. Two interactions were predicted: girls in the intervention group at post-test were expected to demonstrate more gender-neutral to nontraditional job interests than boys in the intervention group and intervention participants in the fifth grade would demonstrate more gender-neutral to nontraditional interests than those participants in the second grade. 
A second research question asked in this study was: What is the effect of a shortterm educational intervention on children's self-report of personal attributes identified as stereotypically feminine and masculine? It was predicted that regardless of gender or grade, there would be a significant difference between intervention and control participants at post-test in terms of their self-reported personal attributes. It was expected that there would be an interaction of girls in the intervention group at post-test would have fewer stereotypic beliefs than boys in the intervention group and all intervention participants in the fifth grade would have fewer stereotypic beliefs than participants in the second grade.

A final research question addressed in this study was: What is the effect of a short-term educational intervention on the perceived competence of children? It was predicted that, regardless of gender or grade, intervention participants would score higher than control children at post-test in terms of their perceived competence in scholastic, social, athletic, physical, and behavioral domains, and in global self-esteem. Girls in the intervention group were expected to rate themselves higher at post-test in the area of perceived competency than boys, and intervention participants in the fifth grade were expected to demonstrate higher self-reported perceived competence than participants in the second grade. 


\section{Chapter II}

$\underline{\text { Method }}$

\section{$\underline{\text { Participants }}$}

Participants for the study were members of intact classrooms from the second and fifth grades at a medium-sized school in the New England area. The school population is primarily European-American and middle-class, with a fairly equal distribution of boys and girls. One classroom from each grade level was randomly assigned to the intervention group and one from each grade level to the control group. The total of 79 participants were distributed by condition, gender, and grade as shown in Table 1.

\section{Table 1}

Summary of Number of Participants by Gender, Grade and Condition

\begin{tabular}{lcccc}
\hline & \multicolumn{2}{c}{ Intervention } & \multicolumn{2}{c}{ Control } \\
\hline & Boys & Girls & Boys & Girls \\
\cline { 2 - 5 } Grade 2 & 7 & 12 & 10 & 9 \\
Grade 5 & 9 & 11 & 10 & 11 \\
\hline
\end{tabular}

$\underline{\text { Measures }}$

Occupational Choice Survey (OSC). Each child was questioned verbally and asked to list three jobs s/he would most like to do when they grow-up. Answers were coded, according to the sex of the child, by independent raters using the following scale: traditional $=1$, neutral=2, and non-traditional=3. Inter-rater reliability conducted with two 
raters in this study on all 78 responses was found to be .81 using Cohen's Kappa formula and to be .95 using the Spearman-Rho formula.

Stereotypic Occupational Scale (SOS). This paper/pencil survey constructed by the examiner is a 3-part scale (see Appendix A) that asks each child about how well "You", "a MAN" or "a WOMAN" would like a specified job. The survey consisted of a list of 18 jobs: 6 traditional/ stereotypic male jobs (doctor, lawyer/judge, police officer, car mechanic, construction worker, engineer), 6 traditional/ stereotypic female jobs (secretary, nurse, elementary school teacher, house keeper, sales clerk, dental hygienist) and 6 neutral jobs (zoo keeper, singer, cook, tennis player, artist, news caster). Response selections included: $1=$ not at all, $2=$ maybe, $3=$ pretty much, $4=$ a lot regarding interest in a specific job. For each subscale of "You," "a MAN," and "a WOMAN," scores were calculated for stereotypic masculine, feminine and genderneutral jobs with scores ranging from 6 (no interest) to 24 (a lot of interest). Items were selected based on previous research where children rated jobs (Nihlen \& Bailey, 1990) as stereotypic "male only" and as jobs that both men and women would do (i.e., gender neutral occupations). In their study, the category of "female only" did not significantly distinguish between jobs. For the present scale, six careers were selected as stereotypically female from a list of occupations with current inclusion of $66 \%$ or more of women (Wright \& Dwyer, 1990). Test/re-test reliability scores on the SOS were calculated for the control group on all 9 subscales (3 variations of "You," "a MAN," or "a WOMAN," for stereotypic masculine, feminine or gender neutral jobs), using pre-test and post-test scores. Low to moderate correlations were obtained ranging from .46 to 
.79 , with a median of .75 (for the complete set of correlation coefficients, Table 14 , Appendix T).

The Children's Sex Role Inventory- Short Form (CSRI; Boldizar, 1991). This measure (see Appendix B) of self-reporting sex type and androgyny in children is based on the Bem Sex Role Inventory (BSRI). Children are presented with a statement (4 "masculine," 4 "feminine," 4 "neutral") and asked to rate themselves according to "how true of you" on a 4-point scale (4=very true of me, $3=$ mostly true of me, $2=a$ little true of me, and $1=$ not at all true of me). Masculine and Feminine subtest scores are computed by averaging the responses to the 4 items on each scale and could therefore range from 1-4.

The measure has demonstrated moderately reliable internal consistency estimate, (alpha $=.81$ ), and stability over a 1-year period $(r=.64)$. Scores on the CSRI have been found to be predictive of toy and activity preferences, self-perceptions, and cognitive abilities (Boldizar, 1991). High correlations ( $r=.88$ ) were also found between the CSRI and the BSRI. Scores on the Short CSRI M and F scales were significantly correlated with those from the long form.

The Self-Perception Profile for Children (SPPC; Harter; 1985). This scale (see Appendix C) consists of six separate sub-scales that assess children's self-perceptions of global self-worth, scholastic competence, social acceptance, athletic competence, physical appearance, and behavioral conduct. Each sub-scale consists of six items, each of which is followed by a description of two types of "kids": one who is "like" the item and another who is not. First the child is asked to determine which kid is most like 
himself/herself, and then is asked to decide if it is "really true" or "sort of true." Scores are summed for each subscale, a mean score was then calculated for each area mean scores ranged from 1.0 (lowest perceived competency) to 4.0 (highest perceived competency). Harter reports internal reliability estimates ranging from .78 to .84 . Several studies using Harter's earlier scale report moderate validity and reliability. Tanaka and Westerman (1988) found moderate correlations between subscales of the earlier scale and the maternal-rated social competence measure of the Child Behavior Checklist.

\section{Procedure}

An introductory letter (see Appendix D) from the investigator, the classroom teacher and school principal was sent to the parents to provide them with background information about the study. A second letter (see Appendix E) was sent in the mail describing the study in detail with a request for parental consent for their child to participate in the study (see Appendix F). A self-addressed, stamped envelope was enclosed. After a one-week period, a follow-up phone call was made to those who did not respond. A second call was made if necessary. Eighty-six of the 102 parents (i.e., $84 \%$ ) gave consent for their child to participate in the study.

Those children who had obtained parental permission were given a verbal overview of the project (researcher read the assent form which also describes project) (see Appendices $\mathrm{G}, \mathrm{H}$ for forms for each grade level) and an opportunity to decide if they wanted to be a part of the study. Each child was given a slip of paper with a space for their name and a box to check ("yes, I am interested in participating in the study" 
or "no, I am not interested in participating in the study"). Those who checked that they were interested in participating in the project were told further about the assent form, emphasizing that they could quit at any time and that they did not have to participate if they did not want to, that they would not be penalized for not participating. Then, each child who expressed interest was interviewed individually by the examiner and was read the assent form one more time to be sure that each child understood his/her rights. A teacher witnessed the assent procedure and asked the children if they understood what had been said. Children who said that they understood and wanted to participate were then presented with the assent form to sign; the form was also signed by the witness and researcher. Children who did not want to be part of the study were thanked and dismissed back to their classroom. A total of 79 students out of a pool of 86 agreed to participate. Before and after each session, the children were asked by their classroom teacher if they had any questions or concerns about the study. The teacher was told to express any concerns to the researcher and to assure the children that if they were uncomfortable they could leave the study.

Random assignment was used to determine which of eight classrooms would become intervention and which would become control. One intervention condition and one control classroom were selected from the second and fifth grades. Pre-tests were administered by the investigator in the following order: OCS, SOS, CSRI, and SPPC. Two sessions, conducted in each individual classroom, were required to complete the pre-tests. 
The intervention groups were then exposed to three 30 to 45 minute curriculum interventions in their classrooms on three consecutive days. All intervention groups were conducted by this researcher. The design of the intervention program was to expose participants to a variety of role models in nontraditional fields beginning with fictional stories about men and women in nontraditional careers, progressing toward a nonfictional story and finally to a panel discussion with live models. On Day 1, they were read two fictional stories about nontraditional workers - one with a female central character ("The ABC's of What a Girl Can Be," Epstein, 1980) and one with a male central character ("A Childhood Dream Comes True," see Appendix I), followed by a guided discussion (see Appendix J for Guided Discussion Questions). "The ABC's of What a Girl Can Be" is a picture/story book that illustrates and talks about women in twenty-six stereotypically masculine roles. "A Childhood Dream Comes True" is a short story about a young boy who dreams about and actually becomes an elementary school teacher. The two readings were chosen in order to encourage students to imagine men and women in nontraditional careers. On Day 2 they were read a nonfictional story about a nontraditional worker ("You Can be a Woman Engineer," Cohen, 1991), followed by a guided discussion. This nonfictional story was an autobiography written by a women engineer. The emphasis of the story was her interest in mathematics and science and how these interests led her to become an engineer. On Day 3, they heard a panel discussion among 5 workers, two traditional (a businessman and a male politician/lawyer), two nontraditional (a male nurse and a woman police officer), and a woman who does traditional and nontraditional jobs (cleaning, manicurist, wall-paper 
hanger and does lobster fishing), followed by a guided discussion. The panel discussion was held in a small area used for presentations and was attended by all the intervention participants. First each panel member talked about their specific work interest, including what they had to be good at to accomplish their job. They also talked about people who influenced their decisions, and the amount of preparation necessary for training for their line of work. After the formal panel discussion, the floor was opened up to participants for questions. The discussion was filmed so that those who were absent would be able to review the tape. The control participants did not receive any treatment during this time.

A post-test on all four measures (OCS, SOS, CSRI, \& SPPC) was then administered to both the intervention and control groups two weeks after the start of the study. This phase of the study took place within the individual classrooms.

An individual interview was conducted with 71 students ( 37 girls and 34 boys; 34- 2nd graders and 37- 5th graders; 39- in the intervention group and 32 controls). Interviews (see Appendix $\mathrm{K}$ ) were held in the investigator's office. Permission to audiotape and transcribe the sessions were obtained in the original consent form. All of the participants agreed to be interviewed. Only those who were absent during the scheduled interview dates were omitted. Every effort was made to make the children comfortable and they were told they could stop at any time. In the interview, children were asked questions about jobs they would like to do and why, what they knew about jobs and what jobs a person of the other sex would select and why. 
The intervention materials were made available to control group students in the control group in June of 1993 after all data were collected. 
Chapter III

\section{$\underline{\text { Results }}$}

\section{$\underline{\text { Introduction }}$}

Quantitative analyses were conducted using several statistical procedures to evaluate the benefits of a short-term educational intervention on choices made by second and fifth grade girls and boys regarding careers, self-attributions and perceived competence. Pre-test and post-test scores were obtained on 18 dependent measures, including The Occupational Choice Survey, The Stereotypic Occupational Survey (with 3 Masculine, Feminine, \& Gender Neutral subscales for "YOU," "A MAN," \& "A WOMAN"), The Children's Sex-Role Inventory (Masculine \& Feminine Scales), and The Self-Perception Profile for Children (6 sub-tests: Scholastic, Social, Athletic, Physical, Behavioral, \& Global). Data from the interview process were analyzed qualitatively to further explore beliefs about potential career choices of "the self" and "a person of the opposite sex." Each interview question was coded for themes. Chi square analyses were conducted to evaluate significant differences associated with gender and development (i.e., grade) differences in themes.

\section{Quantitative Analyses}

Preliminary Analyses. Descriptive statistics for all 18 dependent measures were examined for violation of assumptions. Means and standard deviations for each of the eighteen (18) dependent measures are shown in Appendix T (see Tables 18-35). A liberal critical value of $\mathrm{p} \leq .10$ was set for interpreting all analyses due to the exploratory nature of this study and, as such, is subject to increased experiment-wise error. Results 
indicate that gender differences with boys rating themselves consistently on stereotypical masculine subtests and girls rating themselves higher on stereotypic feminine subtests. On the Perceived Competency measure, boys rated themselves higher on the scholastic and athletic subscales. Second grade participants, in general, expressed greater interest in stereotypic masculine, feminine and gender-neutral jobs at pre-test than grade five participants.

As a preliminary step in the analysis of the data, eighteen $-2 \times 2 \times 2$ (gender $\mathrm{x}$ grade $\mathrm{x}$ intervention condition) analyses of variance (ANOVA) were conducted to determine group equivalence at pre-test on all dependent measures. Although there were no differences between the intervention and control groups at pre-test, there were preintervention group differences by gender and grade (see Appendix T, Tables 15-17) on all dependant variables. Analyses of covariance (ANCOVA) at post-test using pre-test dependent measures as covariates were therefore conducted on all dependent measures to control for group differences at pre-test since random assignment to treatment was not possible (Cambell \& Stanley, 1963).

Children's Perception of Future Occupational Choices. A $2 \times 2 \times 2$ factorial analysis of covariance (ANCOVA) was conducted to examine the main and interaction effects of intervention condition, grade and gender on children's occupational choices at post-test. Pre-test scores were used as the covariate in this analysis and the covariate was significant, $\underline{F}(1,77)=132.00, \underline{p}<.001$. The complete results of this analysis are shown in Appendix T, Table 36. 
Girls made fewer traditional career choices than did boys. There was a highly significant main effect of gender, $\underline{F}(1,77)=11.87, \underline{p}<.001$, with girls scoring closer to the neutral part of the scale $(M=5.95)$, and boys scoring in the traditional range $(M=3.61)$. Contrary to prediction, there were no effects of the intervention, nor of grade level.

Stereotypic Occupational Scale (SOS). (Dutton, 1993). Nine 2 × 2 × 2 analyses of covariance (ANCOVA) were conducted to examine the main effects of intervention condition, gender and grade on each of the dependent subscales of the SOS. Pre-test subtest scores were used as the covariate. Tables 39 and 40 in Appendix T present summaries of the ANCOVA analyses for all SOS measures.

"You" subtests, on the You - Masculine subscale, there were no gender or age main effects, nor were there any significant 2 or 3-way interactions (see Appendix T, Table 41). Contrary to prediction, the intervention was not successful in altering children's interest in the stereotypic masculine careers.

On the YOU-Feminine subtest, there was no main effect for gender, grade, or intervention condition, but a significant 3-way interaction. Simple effects tests were conducted. Boys in the intervention group scored lower $(M=8.38)$ than girls in the intervention group $(M=13.45)$ had the higher score in YOU-Feminine responses $\underline{F}(1,37)$ $=5.51, \mathrm{p}<.025$. Second grade girls in the intervention scored higher $(\mathrm{M}=15.92)$ than fifth grade girls in the intervention group $(M=10.50) \underline{F}(1,37)=42.88, \underline{p}<.007$. Second grade girls in the intervention condition scored higher $(M=15.92)$ than second grade boys in the intervention condition $(\mathrm{M}=8.29) \mathrm{F}(1,37)=4.48, \underline{\mathrm{p}}<.042$. 
In the intervention condition fifth grade girls' interest in stereotypic feminine careers (You-Feminine subscale) was significantly lower than second grade girls in the intervention group. Second grade girls clung more closely to stereotypic choices after the intervention. However, second grade boys scored significantly lower in stereotypic feminine careers after the intervention.

On the YOU-Neutral subtest, there were significant main effects for gender, $\underline{F}(1,77)=4.88, \underline{p}<.05$, and for the intervention condition, $\underline{F}(1,77)=3.06, \underline{p}<.05$. Girls scored significantly higher $(M=12.74)$ than boys $(M=8.97)$. Participants in the intervention group scored higher $(M=11.32)$ than control participants $(M=10.7)$. A $2 \times 2$ (grade $\mathrm{x}$ intervention condition) post hoc analysis of covariance was conducted to further analyze a 2-way interaction between grade and intervention condition $\underline{F}(1,77)$ $=5.26, \underline{\mathrm{p}}<.025$. There was a significant main effect for grade, $\underline{\mathrm{F}}(1,77)=3.24, \underline{\mathrm{p}}<.08$, as well as a significant main effect of intervention, $\underline{F}(1,77)=3.68, \underline{p}<.059$. Among intervention participants there was a significant difference between scores of second and fifth graders, $\underline{F}(1,37)=8.34, \underline{p}<.007$. Fifth graders scored significantly lower on the YOU-Neutral subtest $(\mathrm{M}=10.05)$ than second graders $(\mathrm{M}=15.0)$. Among controls, there was no significant difference between second and fifth graders in YOU-Neutral scores. Among second graders, there was a significant main effect of intervention condition, $\underline{F}(1,37)=7.49, \underline{p}<.01$ with those in the intervention group scoring higher $(M=15.00)$ than control participants $(M=14.37)$. Among fifth grade participants there was no significant main effect of intervention condition. 
On the You-Neutral subtest, girls in the intervention were significantly higher than boys' interest in gender neutral careers (You-Neutral subtest). Contrary to predictions, the interest of fifth grade participants in neutral careers were lower after intervention, whereas second grade intervention participants' interest in gender neutral careers were higher.

"MAN" Subtests. After partialling out the effects of Pre-test scores, a significant grade by intervention condition interaction, $(\underline{F}(1,77)=37.83, \underline{p}<.06)$ was found on the Man-Masculine subscale. Fifth grade intervention participants scored lower $(M=18.80)$ than second grade intervention participants $(M=20.89)$. There were no main effects of intervention condition when analyzed by grade. Among intervention participants, there was a significant main effect of grade, $\underline{F}(1,38)=4.28$, $\underline{p}<.046$, with second graders scoring significantly higher $(M=20.89)$ than fifth graders $(M=18.80)$. Among the control group, there were no differences on MAN-Masculine scores. There was no overall gender difference. There was a significant 2-way interaction between grade and intervention condition, $\underline{F}(1,78)=5.01, \underline{p}<.028$. Among second graders, there was a significant main effect of intervention condition, $\underline{F}(1,37)=6.98, \underline{p}<.012$, with the intervention group scoring higher $(M=14.05)$ than control participants $(M=11.95)$. Among control participants, there was a significant main effect of grade, $(\underline{F}(1,39)=3.99$, $\mathrm{p}<.05)$, with fifth graders scoring higher $(\mathrm{M}=12.29)$ than second graders $(\mathrm{M}=11.95)$ on the Man-Feminine scale. As predicted, the intervention group was successful in altering stereotypic beliefs about men in stereotypically feminine careers. There were no gender differences. 
On the Man-Feminine subscale, there was a significant main effect for intervention, $\underline{F}(1,77)=3.77, \underline{p}<.06$, with the intervention group scoring higher $(M=$ 13.64) than the control group ( $M=12.13)$.

There were no significant main effects for gender, grade or intervention condition on the Man-Neutral subtest. There was a significant, 2-way interaction between grade and intervention condition $\underline{F}(1,78)=9.94, \underline{p}<.002$. Among second graders, the intervention group scored higher $(M=17.89)$ than the control group $(M=16.36) \underline{F}(1,37)$ $=9.89, \mathrm{p}<.003$. Within the intervention group, there was a significant difference, $\underline{F}(1,38)=4.13, \underline{p}<.05$ between second and fifth grade participants, with second graders scoring higher $(M=17.89)$ than fifth graders $(M=16.00)$. Among control participants, there was a significant difference between second and fifth graders, $\underline{F}(1,39)=8.19$, $\mathrm{p}<.007$, with second graders scoring higher $(M=16.35)$ than fifth graders $(M=15.81)$.

"WOMAN" Subtests. Results of the WOMAN-Masculine analyses (see Table 43 in Appendix $\mathrm{T}$ ) indicated a main effect of intervention condition, $\underline{F}(1,77)=3.11$, $\mathrm{p}<.08$ with intervention participants rating women higher $(\mathrm{M}=13.79)$ than control participants $(\mathrm{M}=12.55)$. No other significant main effects or interactions were noted.

On the WOMAN-Feminine subscale, there was a significant main effect of grade, $\underline{F}(1,78)=6.12, \underline{p}<.016$, with second graders scoring higher $(M=19.61)$ than fifth grade participants $(M=17.54)$. No other significant main effects or interactions were noted.

On the WOMAN-Neutral subscale, there were no significant main effects for gender, grade or intervention condition. There was a significant 2-way interaction between gender and grade, $\underline{\mathrm{F}}(1,78)=2.98, \mathrm{p}<.09$, with fifth grade girls rating women 
higher in gender-neutral careers $(M=17.00)$ than fifth grade boys $(M=15.8)$. No other significant main effects or interactions were noted (See Tables 28 \& 29 in Appendix T). Intervention participants were more likely to accept men in traditional feminine roles and women in traditional masculine roles, but the changes were mostly nonsignificant. Second grade intervention participants increased their acceptance of others in nontraditional roles and of self in gender neutral roles, but second grade girls held more rigidly to traditional feminine career beliefs for themselves after the intervention and second graders strongly rejected such careers for themselves. In general, girls were more likely than boys to choose nontraditional and gender neutral jobs both for others and themselves.

Children's Perceptions of Gender-Roles/Sex-Typing. A $2 \times 2 \times 2$ factorial analysis of covariance (ANCOVA) was conducted to examine the main effects and interaction effects of intervention condition, grade and gender on the self-reported sextype scores of children - examining masculine and feminine scores separately.

Results of the analysis (see Table 44 in Appendix T) suggest there was no main effect for gender, grade or intervention on either the masculine or feminine subscales. Pre-test scores were used as the covariates in these analyses. A significant 2-way interaction (gender $\mathrm{x}$ intervention) was found on the masculine subscale, $\underline{F}(1,77)=3.39$, $\mathrm{p}<.07$; in the intervention group, boys' scored higher $(\mathrm{M}=2.58)$ than girls $(\mathrm{M}=2.05)$. A significant 2-way interaction (gender $\mathrm{x}$ intervention) was also found on the feminine subscale, $\underline{\mathrm{F}}(1,77)=9.13, \mathrm{p}<.004$. For the intervention group, boys' scored higher $(\mathrm{M}=3.22)$ than girls $(\mathrm{M}=3.18)$. 
Contrary to prediction, boys in the intervention group scored significantly higher on both the masculine and the feminine sub=test than the girls. There were no differences between grade levels.

Children's Perceived Competence. Six $2 \times 2 \times 2$ factorial analyses of covariance (ANCOVA) were conducted to examine the main effects of intervention condition, grade and gender on perceived competence of children for each of the 6 subscales (i.e., scholastic, social, athletic, physical, behavioral, global self-esteem).

There was a gender by intervention interaction, $\underline{F}(1,77)=3.01, \underline{p}<.09$ on the Scholastic scale (Appendix T, Tables 46 and 47), with boys in the intervention condition rating themselves significantly higher $(M=3.39)$ than boys in the control group $(M=2.77)$. On the Social scale, there was a gender by grade interaction, $\underline{F}(1,77)=3.02$, $\mathrm{p}<.09$, with second grade boys rating themselves higher $(\mathrm{M}=3.06)$ on social perceived competence than second grade girls $(M=2.67)$. On the Athletic scale there was a significant grade by intervention interaction, $\underline{F}(1,77)=3.19, \underline{p}<.08$ with second grade intervention participants rating themselves higher $(M=3.05)$ than second grade control participants $(M=2.59)$, and fifth grade intervention participants rating themselves lower $(M=2.78)$ than fifth grade control participants $(M=3.03)$. There was a highly significant main effect of intervention on the behavior subscale, $\underline{F}(1,74)=13.17, \underline{p}<.001$, with intervention participants rating themselves significantly higher $(M=3.35)$ on perceived competence of behavior than control participants $(M=2.97)$. There were no significant main effects or interactions found on the Global self-esteem scale. Pre-test scores for each of the 6 sub-scales were used as the covariates in these analyses. 
$\underline{\text { Additional Analyses }}$

Paired t-tests were conducted on all of the data for all possible combinations (see Tables 48-65 in Appendix T) to further evaluate change from pre-test to post-test. Due to the number of comparisons, the alpha level was adjusted to a more conservative level ( $\mathrm{p} \leq .06)$ than for the previous analyses, using the Bonferroni Test (Keppel, 1982, p. 148) to reduce the possibility of a Type I error.

On the Occupational Choice Survey (OCS) significant changes from pre-test to post-test were found for the intervention group participants $(\mathrm{p}=.002)$, intervention boys $(\mathrm{p}=.009)$ and intervention girls $(\mathrm{p}=.021)$, fifth grade intervention group ( $\mathrm{p}=.004)$, among girl participants $(\mathrm{p}=.011)$, grade five girls $(\mathrm{p}=.015)$ and among grade five participants $(\mathrm{p}=.004)$. The changes in scores indicate greater acceptance of gender neutral careers themselves after the intervention. These changes can be seen in Table

2.

Table 2

Means and Standard Deviations for Paired t-tests on Significant Findings on The Occupational Choice Survey (OCS).

\begin{tabular}{lcccc}
\hline & \multicolumn{2}{c}{ Pre-test } & \multicolumn{2}{c}{ Post-test } \\
\cline { 2 - 5 } & $\mathrm{M}$ & $\mathrm{SD}$ & $\mathrm{M}$ & $\mathrm{SD}$ \\
\hline Intervention & 4.39 & 1.59 & 4.95 & 1.63 \\
Grade 5 & 4.55 & 1.62 & 4.98 & 1.80 \\
Intervention 5th & 4.42 & 1.47 & 5.00 & 1.67 \\
Girls & 5.38 & 1.59 & 5.95 & 1.65 \\
Girls 5th & 5.67 & 1.43 & 6.24 & 1.51 \\
Intervention Girls & 5.14 & 1.61 & 5.82 & 1.50 \\
Intervention Boys & 3.38 & .81 & 3.75 & .86 \\
\hline
\end{tabular}


On the YOU-Masculine Scale, a significant change from pre- to post-test was found among intervention participants $(p=.027)$, among intervention girls $(p=.005)$, girl participants $(\mathrm{p}=.002)$, girls in grade two $(\mathrm{p}=.019)$ and five $(\mathrm{p}<.057)$, grade five participants $(p=.017)$ and grade five control group participants $(p=.044)$. In all groups, changes from pre to post were in the predicted direction with greater acceptance of stereotypically masculine careers at post-test (see Table 3).

On the YOU-Feminine subtest, intervention participants changed significantly from pre-test to post-test $(\mathrm{p}=.002)$, as did fifth grade girls $(\mathrm{p}=.014)$, girl participants in the intervention group $(\mathrm{p}=.012)$ and grade two intervention participants $(\mathrm{p}=.010)$. Changes in fifth grade participants $(p=.002)$ and fifth grade control participants ( $p$ $=.009$ ) were also significant. Changes from pre- to post-test were as predicted (see Table 4), indicating greater acceptance of feminine careers.

Table 3

Means and Standard Deviations for Paired t-tests for Significant Findings on The Stereotypic Occupational Scale- YOU-Masculine Subtest

\begin{tabular}{lrccc}
\hline & \multicolumn{2}{c}{ Pre-test } & \multicolumn{2}{c}{ Post-test } \\
\cline { 2 - 5 } & \multicolumn{1}{c}{$\mathrm{M}$} & $\mathrm{SD}$ & $\mathrm{M}$ & $\mathrm{SD}$ \\
\hline Intervention & 11.55 & 3.95 & 12.37 & 3.44 \\
Girls Grade 2 & 9.95 & 3.57 & 11.10 & 3.40 \\
Girls Grade 5 & 10.52 & 3.40 & 11.33 & 3.34 \\
Girls & 10.24 & 3.46 & 11.21 & 3.33 \\
Control Grade 5 & 9.76 & 3.16 & 10.95 & 3.31 \\
Grade 5 & 10.80 & 3.35 & 11.73 & 3.19 \\
Intervention Girls & 10.73 & 3.60 & 12.00 & 3.24 \\
\hline
\end{tabular}


Table 4

Means and Standard Deviations for Paired t-tests for Significant Findings on The Stereotypic Occupational Scale- YOU-Feminine Subtest

\begin{tabular}{lcccc}
\hline & \multicolumn{2}{c}{ Pre-post } & \multicolumn{2}{c}{ Post-test } \\
\cline { 2 - 5 } & $\mathrm{M}$ & $\mathrm{SD}$ & $\mathrm{M}$ & $\mathrm{SD}$ \\
\hline Intervention & 10.18 & 3.70 & 11.32 & 3.44 \\
Intervention Grade 2 & 11.58 & 4.39 & 13.11 & 5.18 \\
Girls Intervention & 12.09 & 3.62 & 13.45 & 4.35 \\
Girls Grade 5 & 9.90 & 2.05 & 10.76 & 2.34 \\
Grade 5 & 8.60 & 2.19 & 9.38 & 2.38 \\
Control 5th & 8.43 & 2.25 & 9.24 & 2.84 \\
\hline
\end{tabular}

On the YOU-Neutral scale, a significant difference between pre- and post-test scores was found for girl participants $(\mathrm{p}=.001)$, intervention participants $(\mathrm{p}=.003)$, intervention girls $(\mathrm{p}=.004)$ and intervention second graders $(\mathrm{p}=.001)$, second $=.026)$ and fifth $(\mathrm{p}=.020)$ grade girls, grade five participants $(\mathrm{p}=.038)$ and control participants in the fifth grade $(\mathrm{p}=.036)$, with participants indicating greater acceptance for themselves on YOU-Neutral careers at post-test (see Table 5).

On the MAN-Masculine and MAN-Feminine subscales, no paired t-test combinations reached significance. On the MAN-Neutral subtest there was a significant change from pre- to post-test scores among second grade control participants who scored higher on the Pre-test $(M=18.68)$ than on the Post-test $(M=16.32)$ indicating a lower acceptance at post-test of gender neutral jobs for men by second grade control participants. 


\section{Table 5}

Means and Standard Deviations for Paired t-tests for Significant Findings on The Stereotypic Occupational Scale- YOU-Neutral Subtest

\begin{tabular}{lcccc}
\hline & \multicolumn{2}{c}{ Pre-test } & \multicolumn{2}{c}{ Post-test } \\
\cline { 2 - 5 } & $\mathrm{M}$ & $\mathrm{SD}$ & $\mathrm{M}$ & $\mathrm{SD}$ \\
\hline Intervention & 11.16 & 3.58 & 12.53 & 3.98 \\
Girls & 11.81 & 3.73 & 13.00 & 3.99 \\
Intervention 2nd & 12.95 & 3.79 & 15.00 & 3.76 \\
Girls Grade 2 & 13.95 & 3.68 & 15.33 & 3.76 \\
Grade 5 & 9.23 & 2.52 & 10.03 & 2.75 \\
Control Grade 5 & 9.10 & 2.76 & 10.00 & 3.13 \\
Girls Grade 5 & 9.66 & 2.31 & 10.67 & 2.65 \\
Intervention Girls & 11.73 & 3.91 & 13.36 & 4.23 \\
\hline
\end{tabular}

On the WOMAN-Masculine subtest, significant changes were found from pre-test to post-test among intervention participants $(\mathrm{p}=.003)$, intervention second graders $(\mathrm{p}=.001)$, girls in the intervention group $(\mathrm{p}=.018)$, among girl participants $(\mathrm{p}=.057$, among boy participants $(\mathrm{p}=.019)$ and boys in grade two $(\mathrm{p}=.055)$ and among second grade participants $(\mathrm{p}=.006$ ). All scores increased in the predicted direction with participants more accepting of women in masculine careers (see Table 6).

On the WOMAN-Feminine subtest, significant change scores from pre- to posttest was found among fifth grade participants in the intervention group $(\mathrm{p}=.034)$, with the change reflecting lower scores on feminine job choices for women (Pre: $M=18.9$, $\mathrm{SD}=3.37$; Post: $\mathrm{M}=17.0, \mathrm{SD}=3.81$ ). 
On the WOMAN-Neutral subscales, no paired t-test combinations reached significance. This was also true on the CSRI M and F scales, where no paired t-test combinations reached significance, indicating no change from pre- to post-tests among any of the groups.

Table 6

Means and Standard Deviations for Paired t-tests for Significant Findings on The Stereotypic Occupational Scale- WOMAN-Masculine Subtest

\begin{tabular}{lcccc}
\hline & \multicolumn{2}{c}{ Pre-test } & \multicolumn{2}{c}{ Post-test } \\
\cline { 2 - 5 } & $\mathrm{M}$ & $\mathrm{SD}$ & $\mathrm{M}$ & $\mathrm{SD}$ \\
\hline Intervention & 12.28 & 3.88 & 13.80 & 3.76 \\
Boys & 12.36 & 3.82 & 13.50 & 3.75 \\
Girls & 11.98 & 3.36 & 12.88 & 3.69 \\
Girls Intervention & 12.30 & 3.64 & 13.70 & 3.43 \\
Grade 2 Intervention & 10.16 & 2.57 & 13.00 & 3.51 \\
Boys Grade 2 & 11.18 & 3.99 & 12.94 & 4.19 \\
Grade 2 & 10.92 & 3.35 & 12.55 & 3.80 \\
\hline
\end{tabular}

Paired t-tests were conducted on all of the sub-tests on the Self-Perceived Profile for Children (SPPC). On the Scholastic subtest, significant pre-test to post-test change scores were noted among second grade subjects $(\mathrm{p}=.028)$, girls $(\mathrm{p}=.012)$, participants in the second grade treatment group ( $\mathrm{p}=.036)$, the girls control group $(\mathrm{p}=.006)$ and among second grade girls ( $\mathrm{p}=.004)$. All scores reflected change in the predicted direction (see Table 7). 
Table 7

Means and Standard Deviations for Paired t-tests for Significant Findings on Perceived Competence - Scholastic

\begin{tabular}{lcccc}
\hline & \multicolumn{2}{c}{ Pre-test } & \multicolumn{2}{c}{ Post-test } \\
\cline { 2 - 5 } & $\mathrm{M}$ & $\mathrm{SD}$ & $\mathrm{M}$ & $\mathrm{SD}$ \\
\hline Grade 2 & 2.76 & 0.71 & 2.96 & 0.71 \\
Girls & 2.75 & 0.75 & 2.91 & 0.72 \\
Intervention Grade 2 & 3.00 & 0.61 & 3.26 & 0.51 \\
Girls Control & 2.69 & 0.89 & 2.87 & 0.84 \\
Girls Grade 2 & 2.57 & 0.77 & 2.88 & 0.74 \\
\hline
\end{tabular}

On the Social subscale significant change scores from pre- to post-test were noted among fifth graders $(p=.050)$, girls $(p=.060)$, control participants $(p=.020)$, fifth grade control participants $(\mathrm{p}=.029)$, girls in the control group $(\mathrm{p}=.028)$ and among fifth grade girls $(p=.034)$. All scores reflected a change in the predicted direction (see Table 8).

On the Athletic subscale, significant pre-test to post-test changes were found among intervention participants $(\underline{p}<.022)$ and second grade intervention subjects (p $=.014$ ). Both groups changed in the predicted direction (see Table 9). 
Table 8

Means and Standard Deviations for Paired t-tests Significant Findings on Perceived Competence - Social

\begin{tabular}{lllll}
\hline & \multicolumn{2}{c}{ Pre-test } & \multicolumn{3}{c}{ Post-test } \\
\cline { 2 - 5 } & $\mathrm{M}$ & $\mathrm{SD}$ & $\mathrm{M}$ & $\mathrm{SD}$ \\
\hline Grade 5 & 2.87 & 0.73 & 3.03 & 0.65 \\
Girls & 2.66 & 0.78 & 2.82 & 0.87 \\
Control & 2.71 & 0.79 & 2.92 & 0.78 \\
Control Grade 5 & 2.80 & 0.83 & 3.09 & 0.76 \\
Girls Control & 2.54 & 0.86 & 2.83 & 0.90 \\
Girls Grade 5 & 2.80 & 0.76 & 3.06 & 0.73 \\
Girls Grade 5 Control & 2.67 & 0.88 & 3.17 & 0.79 \\
\hline
\end{tabular}

Table 9

Means and Standard Deviations for Paired t-tests on Perceived Competence - Athletic

\begin{tabular}{lllll}
\hline \hline & \multicolumn{2}{c}{ Pre-test } & \multicolumn{2}{c}{ Post-test } \\
\cline { 2 - 5 } & $\mathrm{M}$ & $\mathrm{SD}$ & $\mathrm{M}$ & $\mathrm{SD}$ \\
\hline Intervention & 2.78 & 0.85 & 2.92 & 0.87 \\
Intervention Grade 2 & 2.83 & 0.76 & 3.05 & 0.85 \\
Intervention Grade 2 - Boys & 3.17 & 0.82 & 3.43 & 0.67 \\
\hline
\end{tabular}

On the Physical subscale, significant pre-test to post-test changes were found among girls ( $p=.053)$, control participants $(\mathrm{p}=.028)$, girls in the control group $(\mathrm{p}=.021)$, and among second grade girls in the control group $(\mathrm{p}=.016)$. All changes were in the predicted direction (see Table 10). 
Table 10

Means and Standard Deviations for Paired t-tests for Significant Findings on Perceived Competence - Physical

\begin{tabular}{lllll}
\hline & \multicolumn{2}{c}{ Pre-test } & \multicolumn{2}{c}{ Post-test } \\
\cline { 2 - 5 } & $\mathrm{M}$ & $\mathrm{SD}$ & $\mathrm{M}$ & $\mathrm{SD}$ \\
\hline Girls & 2.74 & 0.80 & 2.89 & 0.91 \\
Control & 2.82 & 0.75 & 3.01 & 0.77 \\
Girls Control & 2.66 & 0.80 & 2.89 & 0.92 \\
Control Grade 2 - Girls & 2.43 & 0.99 & 2.72 & 0.91 \\
\hline
\end{tabular}

On the Behavioral subscale, paired t-test results indicate a significant change from pre-test to post-test among intervention participants $(\mathrm{p}=.007)$, control subjects $(\mathrm{p}$ $=.045)$, fifth graders in the control group $(\mathrm{p}=.033)$, girls in the control group $(\mathrm{p}=.025)$, boys in the intervention group $(\mathrm{p}=.043)$ and among fifth grade girls in the control group ( $\mathrm{p}=.036$ ). Change scores for the control group, the fifth grade control group and the girls control group indicated a change in the negative direction no change has been predicted, whereas among intervention participants, boys in the intervention group and fifth grade girls in the control group scores reflected a positive change as predicted (see Table 11).

On the Global Perceived Competence subscale significant pre-test to post-test change scores were found among control participants $(\mathrm{p}=.011)$, girls in the control group ( $\mathrm{p}=.025)$ and among second grade girls in the control condition $(\mathrm{p}=.033)$. For all groups, scores reflected a change in a positive direction (see Table 12). No control group changes had been predicted. 
Table 11

Means and Standard Deviations for Paired t-tests for Significant Findings on Perceived Competence - Behavioral

\begin{tabular}{lllll}
\hline & \multicolumn{2}{c}{ Pre-test } & \multicolumn{2}{c}{ Post-test } \\
\cline { 2 - 5 } & $\mathrm{M}$ & $\mathrm{SD}$ & $\mathrm{M}$ & $\mathrm{SD}$ \\
\hline Intervention & 3.15 & 0.54 & 3.35 & 0.54 \\
Control & 3.13 & 0.61 & 2.97 & 0.69 \\
Control Grade 5 & 3.65 & 0.32 & 3.46 & 0.33 \\
Girls Control & 3.39 & 0.50 & 3.13 & 0.78 \\
Boys Intervention & 3.04 & 0.66 & 3.30 & 0.67 \\
Control Grade 5 - Girls & 2.65 & 0.32 & 3.46 & 0.33 \\
\hline
\end{tabular}

Table 12

Means and Standard Deviations for Paired t-tests Significant Findings on Perceived Competence - Global

\begin{tabular}{lllll}
\hline & \multicolumn{2}{c}{ Pre-test } & \multicolumn{2}{c}{ Post-test } \\
\cline { 2 - 5 } & $\mathrm{M}$ & $\mathrm{SD}$ & $\mathrm{M}$ & $\mathrm{SD}$ \\
\hline Control & 2.98 & 0.80 & 3.23 & 0.73 \\
Girls Control & 2.76 & 0.96 & 3.11 & 0.88 \\
Control Grade 2 & 2.29 & 1.00 & 2.89 & 1.08 \\
Grade 2 & 3.01 & 0.84 & 3.18 & 0.79 \\
\hline
\end{tabular}

Correlational Analyses

Correlational analyses were conducted to evaluate the relationship between the YOU-Masculine and YOU-Feminine measures and the Masculine and Feminine subscales of the CSRI at both pre-test and post-test. Results indicate poor concurrent validity between the two scales (see Table 13). 
Table 13

Summary of Correlations Between CSRI and YOU-Dutton Measures at Pre- and Post$\underline{\text { test }}$

\begin{tabular}{lcc}
\hline & Pre-test & Post-test \\
\hline YOU-MASCULINE/CSRI-MASCULINE & .04 & .16 \\
YOU-FEMININE/CSRI-FEMININE & $.33^{* *}$ & .22 \\
BOYS & $(.11)$ & .17 \\
YOU-MASCULINE/CSRI-MASCULINE & & \\
GIRLS & .06 & .01 \\
YOU-FEMININE/CSRI-FEMININE & & \\
\hline
\end{tabular}

Summary of Quantitative Data

The primary question under investigation was whether the presented intervention was successful in altering children's beliefs about adult work, in terms of the acceptance of "others" and "self" in nontraditional jobs. The goal of the intervention was to broaden children's gender schemas, with respect to "careers." In addition, it was predicted that girls would benefit more from the intervention, due to society's high valuation of the male role, and that older children would benefit more from the intervention due to greater flexibility in cognitive processing.

Two statistics (i.e., ANCOVA, paired t-test) were used to evaluate the benefits of the intervention. The intervention was found to be moderately effective in altering children's beliefs about "others" in nontraditional fields. Intervention participants were more likely to accept men in traditional feminine roles and women in traditional masculine roles, but the changes were mostly non-significant. Second grade intervention participants increased their acceptance of others in nontraditional roles and of self in 
gender neutral roles, but second grade girls held more rigidly to traditional feminine career beliefs for themselves after the intervention and second graders strongly rejected such careers for themselves. In general, girls were more likely than boys to choose nontraditional and gender neutral jobs both for others and themselves.

Correlational analyses suggested that neither the CSRI-M nor the CSRI-F are related to choice of traditional careers for "self." Scores on the CSRI masculine or feminine were not predicted by gender. Paired t-tests of pre- and post-test differences indicated no change on CSRI-M or -F scales for any of the groups.

\section{Qualitative Analyses}

Qualitative data analyses of interviews were performed to explore the schemas that children employ in their description of the careers that they are interested in pursuing as adults, as well as the jobs that a "person of the opposite sex would choose."

The 72 interviews were transcribed and the responses that children gave to the seven core questions asked during the interviews were coded. Each job chosen was first coded by seven raters (see Appendix L for Job List). Then each question was coded separately (see Appendices M-S for coding and re-coding schemes). Codes were then collapsed according to similar themes and recoded. Next, chi-square analyses were conducted to assess developmental and gender difference in children's beliefs about future employment for "self" and "a person of the opposite sex." The data were then re-analyzed to determine if there was any thematic information that was not evident in the quantitative analyses. 
To investigate whether there are gender and/or developmental differences in the self-reported career interests of children, three sets of chi-squares $(2 \times 3)$ were performed for each of three jobs selected.

The Chi-Squares were significant for gender regarding feminine, masculine, and gender-neutral jobs $($ Chi Square $=26.61, \underline{p}=.001 ; 17.35, \underline{p}=.001 ; 18.05, \underline{p}=.001$ for Jobs $1,2, \& 3$ respectively). Eight-five percent or more of the boys selected genderstereotypic masculine jobs, whereas only one third of the girls chose such jobs. In contrast, nearly $50 \%$ of the girls chose stereotypically feminine careers, compared to less than $10 \%$ of the boys. Few students of either gender selected gender neutral jobs (i.e., $<10 \%$ ). There were no significant Chi Square results when analyzed by grade.

The reasons given for job choice showed significant gender differences, Chi Square $=14.59, \mathrm{p}<.07 ; 21.11, \mathrm{p}<.007 ; 20.11, \mathrm{p}<.01$ for Jobs $1,2, \& 3$ respectively Seventy-five percent of the girls' responses were coded for nurturing/caring compared to less than $25 \%$ of the boys. Boys' responses were largely split between constructing, powerful roles and a competitive interest in jobs. There were no significant differences in reasons given for job choices between second and fifth graders. There were no gender or developmental differences in children's ideas about what they would have to be good at to perform a specific job.

Chi-Square analyses were significant for gender in how often children report the influence of a family member, Chi-Square $=12.12 ; 10.40, \mathrm{p}=.06 ; 14.30, \mathrm{p}=.014$. Of the $58 \%$ of all children reporting the influence of a family member in choice of a job, $73 \%$ of the girls reported influence of a female relative and $73 \%$ of the boys reported 
the influence of a male relative. Nearly $20 \%$ of all girls reported being influenced by their classroom teacher compared to less than five percent of the boys. Forty percent of all children stated that they did not know a person in the job that they selected.

With respect to jobs the children believed someone of the opposite sex would be interested in, there was a significant gender difference, Chi Square $=31.28, p=.001$; $26.57, \mathrm{p}=.001 ; 17.84, \mathrm{p}=.003$ for Jobs $1,2, \& 3$ respectively. Forty-five percent of all the boys said that girls would choose stereotypic feminine careers, and, approximately two-thirds of the girls stated that boys would chose stereotypic masculine careers. Only five percent of the girls stated that a boy would pick a stereotypic feminine career, and only five percent of all the children said that a person of the opposite sex would select a gender-neutral career. Thirty-seven percent of the entire fifth grade class said that a person of the opposite-sex would choose "any job they want." None of the second graders gave this response.

Do boys offer communal/expressive rationales for girls' interest in a particular job and do girls give agentic/instrumental reasons for boys' interests? Chi-Square analyses were significant by gender, Chi Square $=22.05, \mathrm{p}<.002 ; 17.97, \mathrm{p}=.012 ; 14.08$, $\mathrm{p}=.05$ for Jobs $1,2, \& 3$ respectively, with thirty-three percent of the boys offering a caring/nurturing rationale for a girl selecting a job compared to less than ten percent who attributed this rationale to boys interest in careers. Twenty-eight percent of all the boys gave as a reason for a person of the opposite sex wanting to do a specific job that they had only seen women doing those particular jobs. Of those giving athletic reasons for a person's interest in a particular job, nearly $100 \%$ were girls' reasons for jobs that 
boys would like. Of the 171 responses that indicated an interest in sports or athletics, only one of those responses was in reference to a girls' job choice. Eighty percent of second graders attributed a person of the opposite sex's interest in a career to the fact that they had only seen a woman or man doing that job, compared to $25 \%$ of the fifth graders. Of those who said that a boy or girl could choose any job they like, $93 \%$ were in the fifth grade.

Some of the themes used by boys can be seen in the following excerpt:

Interview with a second grade boy:

I: What three jobs do you think a girl would pick?

C: $\quad$ Secretary, nurse or a doctor.

I: Why do you think a girl would choose a secretary?

C: $\quad$ You see more women secretaries.

I: Why do you think they would pick a nurse or a doctor:

C: $\quad$ My grandmother is a nurse and they should.

I: Girls should be a nurse more, or a doctor?

C: $\quad$ A nurse.

I: What makes you think that?

C: They're good at helping instead of doing. Boys are better at doing.

This response clearly reflects the schema that girls are helpers (communal), whereas boys are doers (instrumental).

The following interview illustrates the influence of the same sex parent and same sex relatives on the stereotypic beliefs boys have acquired about women.

Second grade boy:

I: $\quad$ Name three jobs you think a girl would pick.

C: Secretary, doctor, dental hygienist.

I: Why a secretary?

C: Because sometimes it is a lot more for girls cause sometimes men aren't home and they're doing like, working on cars cause they're a car mechanic and in my opinion a lot of the guys I know, I've asked my father and a lot of my uncles 
if they'd like to be a secretary and they said, "No, that's kinda more for women."

I: Why a doctor?

C: Because sometimes they're like, some women and men would be it and they'd most like it because a lot of people are there. The other thing is maybe they'd work with a lot of patients and we need a lot more doctors because a lot of people are dealing with drugs.

I: What about a dental hygienist?

C: Because I think a lot of people don't usually do that job. A lot of dentists are closed on Saturday and Sunday and if they get a lot more, maybe they can be open on Saturday and Sunday.

I: But why would a woman want to be a dental hygienist?

C: $\quad$ Maybe that will stop a lot more cavities. A lot more patients come at one time and maybe in one month the dentist's office will be closed but there would be a lot of people there.

I: $\quad$ So, the dental hygienist would?

C: $\quad$ Go as fast as they can and making sure all the jobs are done which takes a long time, so maybe if we have more...

I: So a woman wouldn't want to be a dentist, she'd want to be a dental hygienist?

C: Yeah.

I: Why wouldn't a woman want to be a dentist?

C: $\quad$ Cause dentists...usually women want to...they like to go out, go shopping, they like to get it done as fast as they can. That job they kinda have to go slow for.

I: A dentist?

C: Yeah.

I: So a dentist is too slow for a woman to do?

C: Yeah.

There is also evidence of individual differences among younger boys, as illustrated in this interview with a second grade boy.

I: Name three jobs you think a girl would choose?

C: $\quad$ Astronaut, police officer.

I: Why an astronaut?

C: $\quad$ Girls can be anything. There are no girl/boy jobs.

I: Why a police officer?

C: Maybe because they want to try something new. Some people think housecleaning are for just girls. Girls can be anything that they want.

Another fifth grade boy responded quite differently:

I: What three jobs do you think a girl would pick?

C: I would say secretary, day care, dental assistant. 
I: Okay, and why would a girl pick a secretary?

C: $\quad$ Because they're better at the keyboard than men are (laughs).

I: And what about a day care worker?

C: I think a woman would work better with a child.

I: What about a dental hygienist?

C: $\quad$ Because the doctor needs someone there to...they don't have to be strong, but they just have to give them what they need, when they need it.

I: $\quad$ They have to give the man what they need?

C: Yeah. They can also help out and do all the typing.

Another example illustrates that although boys can be liberated in their beliefs about women, they still adhere to some very clear boundaries regarding the type of work men can or should do. This comes from a fifth grade boy of superior intellect:

I: What jobs do you think a girl would pick?

C: Who knows, maybe the same things, maybe not. There are no limit to the amount of jobs there are. There might be jobs that are embarrassing for a guy...like a waitress, a house cleaner.

I: Embarrassing?

C: $\quad$ Might be, who knows. Maybe this person likes doing these types of things. All I know is it would be mighty weird for a boy to be a nurse!

In one interview with a fifth grade girl, she noted that she would be interested in meeting new people while a boy would be interested in making a lot of money, in the same job.

I: Name a job that you would like to do as an adult?

C: Lawyer.

I: What is it about that job that makes you want to do it?

C: I think it's interesting because you meet a lot of people and you get to deal with different things, not just the same thing all the time.

I: What would you have to be good at to do this job?

C: I'd have to be good at defending people and getting my point through and stuff.

I: How do you plan to do this?

C: $\quad$ Go to college and just learn about how to handle kinds of cases.

I: Who do you know who has this job?

C: $\quad$ No one.

I: What jobs do you think a boy would pick? 
C: A lawyer because it pays a lot of money and they get to do a lot of different things.

This is how a fifth grade boy described his interest in law and the jobs he thinks

a girl might select:

I: Name a job that you would like to do as an adult?

C: Lawyer.

I: What is it about that job that makes you want to do it?

C: $\quad$ You get a lot of money.

I: What would you have to be good at to do this job?

C: $\quad$ Have to be smart to think of quotes to say to help the person out.

I: How do you plan to do this?

C: You'd have go through a lot of school for that, a lot of training.

I: Who do you know who has this job?

C: $\quad$ My cousin's friend's father is a lawyer.

I: What jobs do you think a girl would pick?

C: A secretary and maybe a nurse. I've seen a lot of girls be secretaries on TV.

I: What about a nurse?

C: $\quad$ Most girls like to work with people.

One girl who was classified as "androgynous" on the basis of the CSRI and who scored very high on the perceived competence measures, gave the following interesting responses.

I: Name three jobs that you would like to do as an adult?

C: Lawyer, judge, president.

I: What is it about that job that makes you want to do it?

C: $\quad$ (Lawyer) - I like their work - they fight for what they believe in. (Judge) - You make hard decisions and weigh the facts.

(President) - You make the country's decisions and make things in the world run smoothly.

I: What would you have to be good at to do this job?

C: (Lawyer) - Good at working and speaking. (Judge) - Good at making decisions.

(President) - Good at making decisions but make sure they're really good 'cause you can get impeached if you don't.

I: How do you plan to do this?

C: (Lawyer) - Finish school. Go to law school.

(Judge) - Finish school. Go to law school. 
(President) - Work my way up. You can't just go from law school, you have to go from running the school committee and get bigger.

I: Who do you know who has this job?

C: $\quad$ (Lawyer) - My uncle. (Judge) - No one.

(President) - No. My brother shared a birthday with George Bush.

I: What jobs do you think a boy would pick? Why would a boy pick that job?

C: (Mechanic) - They like to work with grease and stuff which I don't mind either.

(Engineer) - It's like working with your hands if you're repairing a refrigerator or computer.

(Lawyer) - It's more powerful.

(Judge) - They get to hit the gavel and be the most powerful in the court.

(President) - They can rule the country.

What is interesting in both this interview and the previous interview is that both of these girls are aware of the power and monetary gains connected with the jobs they are interested in. But only one girl expressed clear interest in salary. Many of her responses were direct and agentic. The following excerpt is from her interview.

I: Name three jobs that you would like to do as an adult?

C: Vet, lawyer, I'd like to work in a pet store. I know I'd rather be a vet or a lawyer because they pay more. Pet shops don't pay too much. Dogs cost $\$ 100$. You don't get it all.

I: What is it about that job that makes you want to do it?

C: (Vet) - (Besides the money.) It'd be fun dealing with some kids of animals. Like dogs and I've always been studying them on how to treat them.

(Lawyer) - (Besides the money.) Because if I was a good lawyer I could be the first lady president in the world. I told my sister. She wants to be the second. (Pet store) - I like dogs and cats and fish and animals like that.

I: What would you have to be good at to do this job?

C: (Vet) - Treating some kinds of animals because some have bad injuries. I pretend to take care of my animals.

(Lawyer) - Arguing with a lot of people. It's all you have to do. I'm really good at it.

(Pet store) - Selling animals.

I: How do you plan to do this?

C: (Vet) - Ask if you could send out a piece of paper.

(Lawyer) - Get a really good degree.

(Pet store) - You don't need a very good degree. 
I: Who do you know who has this job?

C: $\quad$ (Vet) - No one.

(Lawyer) - No, but my mom wanted to be.

(Pet store) - No, but I go a lot and know some people - men and women.

This girl fell within the "undifferentiated" category on the CSRI and scored well below the mean on perceived competence across all areas, including global self-worth.

Three girls and four boys expressed an interest in being a doctor. The girls talked about caring and healing, whereas the boys talked about scientific interest, making money, self-healing and saving money by treating their own sport's injuries. Many girls expressed an interest in teaching, while few boys did. The girls talked about liking children, caring for them and teaching them new things. The boys talked about an interest in teaching math and science. The following excerpt is from an interview with the girl who expressed an interest in math and science.

I: Name three jobs that you would like to do as an adult?

C: $\quad$ Car mechanic, teacher, engineer.

I: What is it about that job that makes you want to do it?

C: $\quad$ (Car mechanic) - I like cars and the parts.

(Teacher) - It seems fun - all the work.

(Engineer) - I like building things.

I: What would you have to be good at to do this job?

C: (Car mechanic) - They replace parts and repair them.

(Teacher) - All the subjects like math and science.

(Engineer) - Math.

I: How do you plan to do this?

C: (Car mechanic) - Go to college.

(Teacher) - Go to all the training.

(Engineer) - Same thing.

I: Who do you know who has this job?

C: (Car mechanic) - No. We have our car fixed a lot, sometimes when we lift up the hood and see all the parts - it interests me.

(Teacher) - My third grade teacher.

(Engineer) - When a couple of them came to our class from the MIT group. 
(I: There was a woman there. How did you feel about that? Did it make a difference that a woman was there? C: Kind of.)

Summary of Qualitative Analyses The qualitative analyses provide further support for the proposition that across developmental levels (i.e., second and fifth graders) the male role is more highly valued than the female role by both boys and girls. Furthermore, although still limited, there appears to be more acceptance for girls crossing gender lines than for boys, particularly among fifth graders. In fact, the data suggest that there is little tolerance for boys crossing gender lines and that, for some, there is shame associated with the thought of men performing stereotypically feminine tasks. The reason given for interest in specific careers also follows communal and agentic themes, with girls seen in the nurturing and care-taking roles and boys in more agentic and instrumental roles (i.e., powerful, constructing, competitive). Boys are seen as doers and girls as helpers.

Few participants expressed interest in nontraditional roles. Nearly all of those who did were girls. Although there were individual differences, the majority of the girls who expressed an interest in nontraditional jobs tended to give a communal or nurturing reason (e.g., doctor, lawyer - to help people). They were less likely to verbalize interest in power or monetary gain for themselves, whereas they clearly communicated that boys/men are interested in "being the boss," "ruling the country," "being powerful" and "making a lot of money."

Many boys stated that they were interested and good in mathematics and science while only one girl voiced an interest in these subjects. Nearly twenty percent of all 
girls stated that they were interested in becoming a classroom teacher and were heavily influenced by their teachers who happen to be all women.

When scores on the measuring instruments were examined in relation to interview data, great variability was evident. Those who chose nontraditional jobs in the interviews did not describe themselves as happier, more social, more competent in scholastic endeavors, more athletic, more behaviorally appropriate or happier with their physique. Some were very happy and others very unhappy, but there were no evident patterns. 


\section{Chapter IV}

\section{Discussion}

This project using a non equivalent control group design (Campbell \& Stanley, 1963) was designed to evaluate the effectiveness of a short-term educational intervention program intended to alter the sex-role beliefs of children regarding careers. A secondary purpose of this research was to contribute to the theoretical advancement of gender schema theory by examining the beliefs of elementary aged children with respect to jobs for "others" and "self" and how these beliefs relate to perceived competency.

Quantitative data were analyzed by the use of ANCOVA to examine the direct effects of the intervention program at post-test, and through the use of paired t-tests to examine the changes from pre-test to post-test. Qualitative analyses were also made of responses to questions during post-intervention interviews. Interview data were coded and chi-squares compared groups with respect to themes. Finally, a subset of the interviews $(\mathrm{n}=14)$ that reflected nontraditional career interests were selected and analyzed in the hope of identifying common themes.

Evidence from the pretest measures indicates that the children involved in this study were well aware of the gender-stereotypes in our gender-schematic culture. This reaffirms Huston's (1983) assertion that culturally-defined sex-roles are learned by the time children enter elementary school. Participants in this study had well-developed gender schemas that included traditional masculine and feminine careers, consistent with expectations from gender schema theory (Bem, 1984). Consistent with Eagly's (1987) views, stereotypic masculine work roles in this study were found to be primarily 
agentic or instrumental, whereas stereotypic feminine work roles were found to be expressive or communal. Regardless of their grade level, the children knew what jobs were considered sex-typed and what were gender-neutral. These findings challenge the conclusions of Bailey and Nihlen (1990) that society has become more egalitarian. The careers identified as stereotypically feminine (i.e., secretary, nurse, elementary school teacher, house keeper, sales clerk, dental hygienist) on the SOS were consistently chosen as jobs that women would do and less-frequently jobs that men would do. Evaluation of Intervention

Results from this exploratory study suggest that the intervention program was not successful in advancing gender-aschematic perceptions of second or fifth grade children of either gender with respect to career possibilities for "self." Boys in the intervention group did not indicate greater interest in stereotypic feminine careers nor did girls indicate an interest in stereotypic masculine careers at post-test as measured by the paired t-tests. These findings are consistent with Bailey and Nihlen $(1988 ; 1990)$ who concluded that gender-roles are difficult to alter in the psychological domain of "the self" but that the domain of "other" in a nontraditional or gender-neutral role is more acceptable. Girls did demonstrate a change from pre-test to post-test in their job choices, but these changes also occurred for girls in the control condition. It should be noted that girls reported a greater interest in stereotypic masculine careers from the beginning, though not to the degree that boys did. It is clear that both boys and girls value stereotypic male careers and that stereotypic female careers are of some interest 
to girls, but not to boys. This supports the feminist argument that our society is patriarchal.

After the intervention, second grade girls' "self" choices of stereotypic feminine careers significantly increased, whereas second grade boys' "self" choices for such careers significantly decreased. For the younger girls and boys, then, the intervention seemed to sharpen their adherence to stereotypes, except that this effect was not found with regard to "self" choices of masculine jobs.

The intervention was successful in increasing girl's interest in gender neutral careers, however this was not true for boys. These findings are consistent with previous studies (Bailey \& Nihlen, 1988, 1990) that indicate the rigidity of sex role orientation for the psychological domain of self. Others suggest that gender schema for the self is very much a part of one's overall self-concept (Bem, 1985) and therefore difficult to change due to societal pressure to conform to prescribed gender roles.

Mixed results were found when evaluating the effects of the intervention on children's perceptions of "others" in nontraditional jobs. Intervention participants were more likely than control participants at post-test to accept men in stereotypic feminine careers and women in stereotypic masculine careers. The changes from pretest scores, however, were modest. Altering children's perceptions about men's interest in masculine careers and women's in feminine careers were not successful, although the fifth graders were less rigid than the second graders in holding on to the traditional stereotypes. In other words, the boys and girls largely maintained their gender stereotypes regarding what men and women choose to do for work. There was evidence 
that the intervention added new information to their previous schemas, but that it did not alter them significantly. For example, men were still believed to be interested in construction work. They might also consider teaching, but they will always be interested in construction. Similarly, women might consider being a doctor, but they will always be nurses.

The second graders, especially girls, more frequently chose gender neutral jobs for "others" and "self" than fifth graders, especially boys. Contrary to the prediction, boys in the intervention group rated themselves higher on both the masculine and feminine scale of the Children's Sex Role Inventory than girls in the intervention group. These high self ratings on communal/expressive traits on the femininity scale of the CSRI were unrelated to the boys' choice of stereotypic feminine careers (which was low). Results of the CSRI did not correlate with choice of stereotypic male or female jobs, thus questioning the validity of the CSRI as a measure of children's gender schemas.

Another result that challenges the validity of the CSRI is that a great majority of the girls who chose nontraditional careers received high scores on the "feminine" scale. Gender schema theory predicts that those who are "sex-typed" have a greater propensity to organize their world in terms of gender (Bem, 1984). One would conclude that girls sex-typed "feminine" would not be interested in aspiring to nontraditional, stereotypical masculine roles. Scores on the CSRI-Masculine scale did not correlate with "self" careers for the entire sample, and only a weak correlation was found between scores on the CSRI-Feminine scale and the "self" career choices. 
On the Self-Perceived Competence Scale, boys rated themselves consistently higher than girls at both pre- and post-test. This is consistent with previous findings and conclusions that boys express higher self-esteem (Tozzo \& Golub, 1990). That similar results were found for the control group are suggestive of the sheer effects of testing or the spread of effect.

\section{Theoretical Issues}

Themes derived from the qualitative analysis support the existence of variability among participants. As expected, most children described their interest in future jobs in conformity with gender stereotypes, and as influenced by a same-sex individual, usually a relative. Many girls were influenced by classroom teachers, whereas few boys were. Of specific theoretical interest is the question of why a girl who indicates an interest in pursuing a career in law would give intellectual or helping reasons for her choice, and then describe a boy's interest in law as due to monetary and power rewards. One might conclude that this young girl has one schema for "woman lawyer" which involves a network of intellectual interests, helping others, etc., and a completely separate schema for male "lawyer." An alternative hypothesis is that while the girl is interested in financial gain, she is aware that it is not socially acceptable for girls to discuss this interest but that it is very socially acceptable for her to express interest in helping others.

Only one girl in the entire sample expressed an interest in mathematics and science. These findings are similar to Campbell's (1992) who concluded that girls have been short-changed in the educational process. While a high percentage of boys 
expressed great interest in participating in professional athletics, not one girl discussed an interest in playing professional sports. It is clear that sports participation is of value in terms of physical development. Since boys have many more opportunities to play and negotiate rules of games, rally for power, compete with others of varying abilities, as well as have the opportunity to learn fair sports conduct, it follows that girls may be missing out on important lessons to prepare them for positions of power and status. Limitations of the Study

The findings of this exploratory study should be interpreted cautiously as a liberal significance level was set at $\mathrm{p}<.10$. The study is also limited by the small number of participants in each condition and by the fact that results are based on children of European-American background and may not generalize to other populations.

Another issue that presents a threat to the internal validity of this study is the issue of the influence of testing - how one measure impacts the results of another measure. In future studies, the Solomon Four design might be helpful in determining the influence of testing on the dependent measures. Simply raising the question of job choices appears to have influenced responses. There were also some unanticipated potential influences. For example, after the intervention was completed, it came to my attention that the fifth grade intervention class had been visited by engineers from M.I.T., including women engineers.

In summary, the intervention itself was not powerful enough to have a substantial impact, although it provided an opportunity for gender-related issues to be raised. Booster sessions might have been useful in reinforcing concepts. The interventions were 
also limited due to the short duration of the program. A more long-range project with both a peer leadership component and a cognitive skill-based training in multiple classifications may have a greater impact on changing stereotypic beliefs. The fifth graders seemed bored with the literature readings, suggesting that biographies or autobiographies at their reading level would present a greater challenge. The second graders were very interested in the intervention and expressed great enthusiasm. An exhaustive computer search for children's literature on men in nontraditional roles, both fiction and nonfiction, yielded only stories depicting fathers in a "mother" role. Perhaps an intervention is best introduced in the second grade since these children were most receptive to the material and were most affected by it. Finally, future interventions should include a program evaluation component to determine participants' acceptability of the program, in addition to a program effectiveness evaluations.

\section{Directions for Future Research}

The issue of power and status needs to be explored with children. Do girls who are interested in nontraditional roles, for example, have separate schemas for women and men in the same occupations or do they feel it is culturally inappropriate for girls to desire the same rewards as boys? Or, it may be that adults continue to socialize young girls into thinking that they do not have to be concerned with making a good living, and assuming that their husband will be the primary bread-winner.

Athletics, mathematics and science continue to be areas in which boys express greater interest. Educators need to be concerned with the classroom conditions and parental attitudes that may be interfering with girls' interests. 


\section{$\underline{\text { Conclusions }}$}

Gender schema theory offers a framework for understanding the development of gender in young children. There is evidence from this study that children continue to process information in terms of gender. Children agree that women and men do different jobs, confirming that stereotypes function as organizing schema. Gender continues to be a prominent stimulus to which they have learned to respond with particular beliefs and associations.

Curriculum interventions need to be developed with a focus on infusing nontraditional concepts into existing curricula. Children's materials about men in nontraditional roles are almost nonexistent and there is a paucity of literature/films about women in nontraditional roles. School personnel need to realize the importance of providing opportunities for all children regardless of gender, to explore a wide variety of adult careers. Providing male and female role models for the same jobs would take the focus off gender and place it on the skills and benefits of specific work. Relevant books and films should be added to social studies, science and math lessons to reinforce concepts of gender diversity.

We need to move away from dichotomizing boys and girls in terms of behavior, attitudes, and beliefs and move toward degenderizing behavior (Lott, 1993). Many (e.g., Bohan, 1993) argue that gender is not a internal structure that exists within individuals, but that is a social construction that is situated within social transactions. Understanding the conditions under which girls and boys learn "to do gender" is a different and profitable approach. Schools need to become aware of how they "do gender," too. 
References

Alpert-Gillis, L. J., \& Connell, J. P. (1989). Gender and sex-role influences on children's self esteem. Journal of Personality, 57, 97-114.

The AAUW Report. American Association of University Women (1992). How schools short change girls. Washington, DC.

Bailey, B. A., \& Nihlen, A. S. (1988). Children's display of gender schemas through interaction with nontraditional workers. Anthropology and Education Quarterly, 19 , $155-162$.

Bailey, B. A., \& Nihlen, A. S. (1990). Effect of experience with nontraditional workers on psychological and social dimensions of occupational sex-role stereotyping by elementary school children. Psychological Reports, $\underline{66}, 1273-1282$.

Bandura, A., \& Walters, R. (1963). Social learning and personality development. New York: Holt, Rinehart and Winston.

Bem, S. L. (1974). The measurement of psychological androgyny. Journal of Clinical and Consulting Psychology, 42, 155-162.

Bem, S. L. (1977). On the utility of alternative procedures for assessing psychological androgyny. Journal of Clinical and Consulting Psychology, 45, 196-205.

Bem, S. L. (1981). Bem Sex Role Inventory professional manual. Palo Alto, CA: Consulting Psychologists Press.

Bem, S. L. (1983). Gender schema theory and its implications for child development: Raising gender-aschematic children in a gender-schematic society. Signs: Journal of Women in Culture and Society, $\underline{8}, 598-616$.

Bem, S. L. (1984). Androgyny and gender schema theory: A conceptual and empirical integration. In T. B. Sonderegger (Ed.), Nebraska Symposium on Motivation: (1984) Psychology and gender, Vol. 32 (pp. 179-226). Lincoln, NE: University of Nebraska Press.

Bem, S. L. (1987). Gender schema theory and the romantic tradition. In P. Shaver and C. Hendrick (Eds.), Review of personality and social psychology, Vol. 7, (pp. 251271). Newbury Park, CA: Sage.

Bem, S. L. (1993). The lenses of gender. New Haven; (CT): Yale University Press. 
Bigler, R. S. \& Liben, L. S. (1990). The role attitudes and interventions in gender schematic processing. Child Development, 61, 1440-1452.

Bigler, R. S., \& Liben, L. S. (1992). Cognitive mechanisms in children's gender stereotyping: Theoretical and educational implications of a cognitive-based intervention. Child Development, 63, 1351-1363.

Bohan, J. S. (1993). Regarding gender: Essentialism, constructionism, and feminist psychology. Psychology of Women Quarterly, 17, 5-21.

Boldizar, J. P. (1991). Assessing sex typing and androgyny in children: The children's sex role inventory. Developmental Psychology, 27, 505-515.

Bussey, K., \& Bandura, A. (1984). Influence of gender constancy and social power on sex linked modeling. Journal of Personality and Social Psychology, 47, 1292-1302.

Calvert, S., \& Huston, A. (1987). Television and children's gender schemata. New Directions for Child Development, $\underline{38}, 75-88$.

Campbell, P. (1993, March). Where are the girls? In Mary Ellen Riley (Chair), Women Studies Lecture Series. Lecture conducted at the University of Rhode Island, Kingston, RI.

Cohen, J. (1992). You can be a woman engineer. Culver City, CA: Cascade Pass.

Constantinople, A. (1973). Masculinity - femininity: An exception to the famous dictum. Psychological Bulletin, $\underline{80}$, 389-407.

Coopersmith, S. (1967). The Antecedents of Self-Esteem. San Francisco: W. H. Freeman.

Deaux, K., Kite, M. E., \& Lewis, L. L. (1985). Clustering and gender schemata: An uncertain link. Personality and Social Psychology Bulletin, 11, 387-397.

Eagly, A. H. (1987). Sex differences in social behavior: A social-role interpretation, Hillsdale, NJ: Erlbaum.

Eagly, A. H., \& Wood, W. (1982). Inferred sex differences in status as a determinant of gender stereotypes about social influence. Journal of Personality and Social Psychology, 43, 915-928.

Eisenberg, N., Wolchik, S. A., Hernandez, R., \& Pasternack, J. F. (1985). Parental socialization of young children's play: A short-term longitudinal study. Child Development, $\underline{56}$, 1506-1513. 
Elliott, S.N., Witt, J.C., Kratochwill, T.R. (1991). Selecting, implementing, and evaluating classroom interventions. In G. Stoner, M.R. Shinn, H.M. Walker (Eds.), Intervention for achievement and behavior problems, Silver Springs, MD: National Association for School Psychologist.

Epstein, V. (1980). The ABC's of what a girl can be. Denver; CO: VSE Publisher.

Erikson, E. H. (1950). Children and society. New York: Norton.

Fagot, B. I. (1985a). A cautionary note: Parents' socialization of boys and girls. Sex Roles, 12 , 471-476.

Fagot, B. I. (1985b). Beyond the reinforcement principle: Another step toward understanding sex role development. Developmental Psychology, 21, 1097-1104.

Hall, J. A., \& Halberstadt, A. G. (1980). Masculinity and femininity in children: Development of the children's personal attributes questionnaire. Developmental Psychology, 16, 270-280.

Harter, S. (1985b). Manual for the self-perception profile for Children: Revised. Denver, CO: University of Denver.

Hattie, J. (1992). Self-Concept. Hillsdale, NJ: Lawrence Erlbaum.

Helmreich, R. L., Spence, J. T., \& Holahan, C. K. (1979). Psychological androgyny and sex role flexibility: A test of two hypotheses. Journal of Personality and Social Psychology, 37, 1631-1644.

Hudak, M. A. (1993). Gender schema theory revisited: men's stereotypes of American women. Sex Roles, 28, 279-293.

Hughes, C. M., Martinek, S. A., \& Fitzgerald, L. F. (1985). Sex role attitudes and career choices. Elementary School Guidance and Counseling, 20, 57-66.

Huston, A. C. (1983). Sex-typing. In P. H. Mussen Handbook of Child Psychology (Vol. 4, pp. 387-467), New York: Wiley.

Jacklin, C. N. (1989). Male and female: Issues of gender. American Psychologist, 44 , 127-133.

Keppel, G. (1982). Design analysis: A researcher's handbook. Englewood Cliffs, NJ: Prentice-Hall. 
Klein, H. A. (1992). Individual temperament and emerging self-perception: An interactive perspective. Journal of Research in Childhood Education, 6 , 113-120.

Kohlberg, L. (1966). A cognitive-developmental analysis of children's sex-role concepts and attitudes. In E. E. Maccoby (Ed.), The Development of Sex Differences (pp. 82172). Stanford, CA: Stanford University Press.

Lamke, L. K. (1982). The impact of sex-role orientation on self-esteem in early adolescence. Child Development, 53, 1530-1535.

Leahy, R. L., \& Shirk, S. R. (1984). The development of classificatory skills and sextrait stereotypes in children. Sex Roles, 10, 281-292.

Levy, G. D., \& Carter, D. B. (1989). Gender schema, gender constancy, and genderrole knowledge: The role of cognitive factors in preschooler's gender-role stereotype attributions. Developmental Psychology, 25, 444-449.

Liben, L. S., \& Bigler, R. S. (1987). Reformulating children's gender schemata. In L. S. Liben \& M. L. Signorella (Eds.), Children's Gender Schemata (pp. 89-105). San Francisco: Jossey-Bass.

Liben, L. S., \& Signorella, M. L. (1980). Gender related schemata and constructive memory in children. Child Development, 51, 11-18.

Lott, A. J., \& Lott, B. E. (1968). A learning theory approach to interpersonal attitudes. In A. G. Greenwald, T. C. Brock, \& T. M. Omstrom (Eds.), Psychological foundations of attitudes (pp. 67-88). NY: Academic Press.

Lott, B. (1985). The potential enrichment of social/personality psychology through feminist research and vice versa. American Psychologist, 40, 155-164.

Lott, B. (1987). Feminine, masculine, androgynous, or human? Paper presented at the meeting of the American Psychological Association, NY, August 1987, as part of the symposium on The future of difference: Representations of gender in psychology ( $\mathrm{J}$. Marecek \& R. T. Hare-Mustin, Chairs).

Lott, B. (1990). Dual natures or learned behavior. In R. T. Hare-Mustin, \& J. Marecek (Eds.), Making a difference: Psychology and the construction of gender (pp. 65-101). New Haven; (CT): Yale University Press.

Lott, B. (1993). Women' lives: Themes and variations in gender learning (2nd ed.). CA: Pacific Grove, Brooks/Cole. 
Lott, B., \& Lott, A. J. (1985). Learning theory in contemporary social psychology. In G. Lindzey \& E. Aaronson (Eds.), Handbook of Social Psychology (3rd ed.). (Vol. 1, pp. 109-135). NY: Random House.

Lott, B., \& Maluso, D. (1993). The social learning of gender. In A. E. Beall, \& R. J. Sternberg (Eds.) The psychology of gender (pp. 99-123). New York: Guilford Press.

Maccoby, E. E. (1990). The role of gender identity and gender constancy in sexdifferentiated development. In New Directions for Child Development, Dawn Shrader (Ed.), San Francisco: Jossey-Bass.

Martin, C. L. \& Halverson, C. F. (1981). A schematic processing model of sex typing and stereotyping in children. Child Development, $\underline{52}, 1119-1134$.

Martin, C. L., \& Halverson, C. F. (1983). The effects of sex-typing schemas on young children's memory. Child Development, $\underline{54}, 563-574$.

Martin, C. L., Wood, C. H., \& Little, J. K. (1990). The development of gender stereotype components. Child Development, 61, 1891-1904.

Mischel, W. (1970). Sex-typing and socialization. In P. H. Mussen (Ed.), Carmichaels' Manual of Child Psychology, 2, pp. 3-72, New York: Wiley.

Mussen, P. H. (1969). Early sex-role development. In D. A. Goslin (Ed.), handbook of socialization theory and research (pp.707-732). Chicago: Rand-McNally.

Nastasi, B. E., \& DeZolt, D. M. (1994). School interventions for children of alcoholics. NY: Guilford.

Nihlen, A. S., \& Bailey, B. A. (1988). Children's display of gender schemas through interaction with nontraditional workers. Anthropology and Education Quarterly, 19 , $155-162$.

Orlofsky, J. L., \& O'Heron, C. A. (1987). Stereotypic and non-stereotypic sex role trait and behavior orientations, Journal of Personality and Social Psychology, 52, 10341042.

Pedhauzur, E. J., \& Tetenbaum, T. J. (1979). The Bem Sex Role Inventory: A theoretical and methodological critique. Journal of Personality and Social Psychology, $\underline{\text { 37, 996-1016. }}$

Piers, E., \& Harris, D. (1969). The Piers-Harris Children's Self-Concept Scale. Nashville, TN: Counselor Recordings and Tests. 
Pietromonaco, P. R., Manis, J., \& Frohardt-Lane, K. (1986). Psychological consequences of multiple social roles. Psychology of Women Quarterly, 10, 373-382.

Signorella, M. L. (1987). Gender schemata: Individual differences and context effects. In L. S. Liben , \& M. L. Signorella, Eds. Children's Gender Schemata, New Directions for Child Development, $\underline{38}$, San Francisco: Jossey-Bass.

Spence, J. T. (1985). Gender identity and its implications for the concepts of masculinity and femininity. In T. B. Sonderegger (Ed.). Nebraska symposium on motivation, 1984: Psychology and gender (Vol. 32) (pp. 59-96). Lincoln, NE: University of Nebraska Press.

Spence, J. T., \& Helmreich, R. L. (1978). Masculinity and femininity: Their psychological dimensions, correlates, and antecedents. Austin: University of Texas Press.

Stangor, C. \& Ruble, D. (1987). Development of gender role knowledge and gender constancy. In L. Liben \& M. Signorella (Eds.) Children's Gender Schemata, New Directions for Child Development, $\underline{38}$, San Francisco: Jossey-Bass.

Tanaka, J. W., \& Westerman, M. A. (1988). Common dimensions in the assessment of competence in school-aged girls. Journal of Educational Psychology, 80, 579-584.

Taylor, M. S., \& Hall, J. A. (1982). Psychological androgyny: Theories methods, and conclusions. Psychological Bulletin, 92, 347-366.

Tozzo, S. G., \& Golub, S. (1990). Playing nurse and playing cop: Do they change children's perceptions of sex-role stereotypes? Journal of Research in Childhood Education, 4, 123-129.

Unger, R., \& Crawford, M. (1992). Women and Gender: A Feminist Psychology. Philadelphia: Temple University Press.

U. S. Bureau of the Census. (1991). Statistical Abstracts of the United States. Washington DC: U. S. Government Printing Office.

Whitley, B. E., Jr. (1985). Sex-role orientation and psychological well-being: Two meta-analyses. Sex Roles, 12, 207-225.

Wright, J. W., \& Dwyer, E. J. (1990). The American Almanac of Jobs and Salaries: NY: Avon Books.

Wylie, R. C. (1989). Measures of self-concept. Lincoln, NE: University of Nebraska Press. 
File \# Appendix A

CHILDREN'S UNDERSTANDING OF ADULT WORK (Stereotypic Occupational Scale (SOS)

How likely is it that YOU would do this job?

CIRCLE your answer

(M) DOCTOR

(F) SECRETARY

(N) ZOO KEEPER

(M) LAWYER/JUDGE

(F) NURSE

(N) SINGER

(M) POLICE OFFICER

(F) ELEMENTARY

SCHOOL TEACHER

\section{1}

not at all

1

12

not at all

1

not at all

1

not at all

12

not at all

12

not at all

maybe

2

maybe

2

maybe
3

pretty much

3

pretty much

3

pretty much

3

pretty much

3

pretty much

3

pretty much

3

pretty much

4

a lot

3

pretty much
4

a lot

4

a lot

4

a lot

4

a lot

4

a lot

4

a lot 
(N) COOK

(F) HOUSE KEEPER

(N) TENNIS PLAYER

(M) CONSTRUCTION WORKER

(F) SALES CLERK

(N) ARTIST

(M) ENGINEER

(F) DENTAL

HYGIENIST

(N) NEWS CASTER

\section{1}

not at all

12

not at all maybe

2

maybe

2

not at all

maybe

2

maybe

2

not at all

1

not at all

2

maybe

2

not at all

maybe

2

not at all maybe

12

not at all

maybe

2

maybe

1

not at all
3

pretty much

3

pretty much

3

pretty much

4

a lot

4

a lot

4

a lot

4

a lot

pretty much

3

pretty much

4

a lot

4

a lot

pretty much

3

pretty much

4

a lot
3

pretty much
4

a lot 
File \#

CHILDREN'S UNDERSTANDING OF ADULT WORK (Stereotypic Occupational Scale (SOS) Continued) How likely is it that a MAN would do this job?

\section{CIRCLE your answer}

(M) DOCTOR

(F) SECRETARY

(N) ZOO KEEPER

(M) LAWYER/JUDGE

(F) NURSE

(N) SINGER

(M) POLICE OFFICER 1

(F) ELEMENTARY SCHOOL TEACHER not at all

1

not at all

1

not at all

1

not at all

1

not at all

1

not at all

1

not at all

2

maybe

2

maybe

2

maybe
3

pretty much

3

pretty much

4

a lot

4

a lot

4

a lot

pretty much

3

pretty much

4

a lot

4

a lot

4

a lot

pretty much

3

pretty much
4

a lot 


\begin{tabular}{|c|c|c|c|c|}
\hline (N) COOK & $\begin{array}{l}1 \\
\text { not at all }\end{array}$ & $\begin{array}{l}2 \\
\text { maybe }\end{array}$ & $\begin{array}{l}3 \\
\text { pretty much }\end{array}$ & $\begin{array}{l}4 \\
\text { a lot }\end{array}$ \\
\hline (M) CAR MECHANIC & $\begin{array}{l}1 \\
\text { not at all }\end{array}$ & $\begin{array}{l}2 \\
\text { maybe }\end{array}$ & $\begin{array}{l}3 \\
\text { pretty much }\end{array}$ & $\begin{array}{l}4 \\
\text { a lot }\end{array}$ \\
\hline (F) HOUSE KEEPER & $\begin{array}{l}1 \\
\text { not at all }\end{array}$ & $\begin{array}{l}2 \\
\text { maybe }\end{array}$ & $\begin{array}{l}3 \\
\text { pretty much }\end{array}$ & $\begin{array}{l}4 \\
\text { a lot }\end{array}$ \\
\hline (N) TENNIS PLAYER & $\begin{array}{l}1 \\
\text { not at all }\end{array}$ & $\begin{array}{l}2 \\
\text { maybe }\end{array}$ & $\begin{array}{l}3 \\
\text { pretty much }\end{array}$ & $\begin{array}{l}4 \\
\text { a lot }\end{array}$ \\
\hline $\begin{array}{l}\text { (M) CONSTRUCTION } \\
\text { WORKER }\end{array}$ & $\begin{array}{l}1 \\
\text { not at all }\end{array}$ & $\begin{array}{l}2 \\
\text { maybe }\end{array}$ & $\begin{array}{l}3 \\
\text { pretty much }\end{array}$ & $\begin{array}{l}4 \\
\text { a lot }\end{array}$ \\
\hline (F) SALES CLERK & $\begin{array}{l}1 \\
\text { not at all }\end{array}$ & $\begin{array}{l}2 \\
\text { maybe }\end{array}$ & $\begin{array}{l}3 \\
\text { pretty much }\end{array}$ & $\begin{array}{l}4 \\
\text { a lot }\end{array}$ \\
\hline (N) ARTIST & $\begin{array}{l}1 \\
\text { not at all }\end{array}$ & $\begin{array}{l}2 \\
\text { maybe }\end{array}$ & $\begin{array}{l}3 \\
\text { pretty much }\end{array}$ & $\begin{array}{l}4 \\
\text { a lot }\end{array}$ \\
\hline (M) ENGINEER & $\begin{array}{l}1 \\
\text { not at all }\end{array}$ & $\begin{array}{l}2 \\
\text { maybe }\end{array}$ & $\begin{array}{l}3 \\
\text { pretty much }\end{array}$ & $\begin{array}{l}4 \\
\text { a lot }\end{array}$ \\
\hline $\begin{array}{l}\text { (F) DENTAL } \\
\text { HYGIENIST }\end{array}$ & $\begin{array}{l}1 \\
\text { not at all }\end{array}$ & $\begin{array}{l}2 \\
\text { maybe }\end{array}$ & $\begin{array}{l}3 \\
\text { pretty much }\end{array}$ & $\begin{array}{l}4 \\
\text { a lot }\end{array}$ \\
\hline (N) NEWS CASTER & $\begin{array}{l}1 \\
\text { not at all }\end{array}$ & $\begin{array}{l}2 \\
\text { maybe }\end{array}$ & $\begin{array}{l}3 \\
\text { pretty much }\end{array}$ & $\begin{array}{l}4 \\
\text { a lot }\end{array}$ \\
\hline
\end{tabular}


File \#

CHILDREN'S UNDERSTANDING OF ADULT WORK (Stereotypic Occupational Scale (SOS) Continued)

How likely is it that a WOMAN would do this job?

CIRCLE your answer

(M) DOCTOR

12

not at all

(F) SECRETARY

(N) ZOO KEEPER

(M) LAWYER/JUDGE

1

not at all

(F) NURSE

(N) SINGER

(M) POLICE OFFICER

(F) ELEMENTARY

SCHOOL TEACHER
1

not at all

1

not at all

1

not at all

2

maybe

2

maybe

2

maybe

2

maybe
3

pretty much

3

pretty much

3

pretty much

3

pretty much

3

pretty much

3

pretty much

pretty much

3

pretty much
4

a lot

4

a lot

4

a lot

4

a lot

4

a lot

4

a lot

4

a lot

a lot

4

a lot 
(N) COOK

(M) CAR MECHANIC not at all

(F) HOUSE KEEPER

(N) TENNIS PLAYER

(M) CONSTRuCTION WORKER

(F) SALES CLERK

(N) ARTIST

(M) ENGINEER

(F) DENTAL

HYGIENIST

(N) NEWS CASTER
1

not at all

1

2

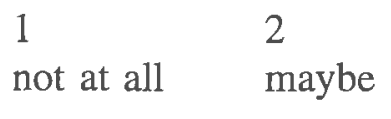

2

maybe

2

maybe

1

not at all

2

maybe

1

not at all maybe

12

not at all maybe

12

not at all maybe

1

not at all maybe

1

not at all
3

pretty much

3

pretty much

4

a lot

4

a lot

4

a lot

4

a lot

pretty much

3

pretty much

4

a lot

4

pretty much

a lot

4

a lot

pretty much

3

pretty much

4

a lot

3

pretty much
4

a lot 
Appendix B

\section{Self-Description Scale: Short Form \\ (Children's Sex-Role Inventory (CSRI)}

DIRECTIONS: Read each of the following sentences carefully, and then put a number between 4 and 1 in the space in front of each one. Rate yourself according to how true of you each one is:

--if it's VERY TRUE of you, put a 4 in the space.

--if it's MOSTLY TRUE of you, put a 3 in the space.

--if it's A LITTLE TRUE of you, put a 2 in the space.

--if it's NOT AT ALL TRUE of you, put a 1 in the space.

Please do not leave any sentence unmarked. This scale will help you remember what the number means.

$\begin{array}{llll}4 & 3 & 2 & 1 \\ \text { VERY TRUE } & \text { MOSTLY TRUE } & \text { A LITTLE TRUE } & \text { NOT AT ALL TRUE } \\ \text { OF ME } & \text { OF ME } & \text { OF ME } & \text { OF ME }\end{array}$

$\mathrm{N}$ __ 1. People like me.

F___2. It makes me feel bad when someone else is feeling bad.

M_3. I can control a lot of the kids in my class.

$\mathrm{N}$ _4. I have many friends.

F__ 5. When someone's feelings have been hurt, I try to make them feel better.

M_6. When a decision has to be made, it's easy for me to take a stand.

N__ 7. It's easy for me to fit into new places.

F__ 8. I am a warm person.

M__. I am a leader among my friends.

$\mathrm{N} \_$10. I'm always losing things.

F__11. I am a kind and caring person.

M__ 12. When I play games, I really like to win. 
File No.

Appendix C

SAMPLE SENTENCE $\begin{array}{cc}\text { Really } & \text { Sort of } \\ \text { True } & \text { True } \\ \text { for me } & \text { for me }\end{array}$

(a)

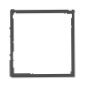

$\square$
Some kids would rather play outdoors in their BuT spare time
Sort of Really

True True

for me for me

Other kids would rather watch T.V.
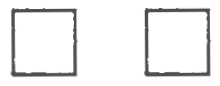

(1)
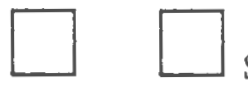

Some kids feel that they are very good at their BLT school work

Other kids worry about
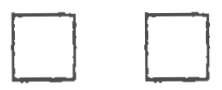
whether they can do the school work assigned to them

(2)<smiles>C1CCC1</smiles><smiles>C1CCC1</smiles>

Some kids find it hard to Other kids find it's pretty<smiles>C1CCC1</smiles><smiles>C1CC2CC12</smiles>
make friends BuT easy to make friends.

(3)<smiles>C1CCC1</smiles><smiles>C1=CCC1</smiles>
Some kids do very well at all kinds of sports BuT

Other kids clon't feel that<smiles>C1CC2CC12</smiles><smiles>C1CCC1</smiles>
they are very good when it comes to sports.

(4)<smiles>C1=CCC1</smiles><smiles>C1CC2CCC12</smiles>

Some kids are happy Other kids are not happy<smiles>C1=CCC1</smiles><smiles>C1=CCC1</smiles>
with the way they look BuT with the way they look.

(5)<smiles>C1CCC1</smiles><smiles>C1CCC1</smiles>

Some kids often do nol

Other kids usually like<smiles>C1=CCC=1</smiles><smiles>C1CCC1</smiles>
like the way they behave BuT the way they bebave.

(6)<smiles>C1CCC1</smiles><smiles>C1CCC1</smiles>

Some kids are often Other kids are pretty<smiles>C1CCC1</smiles><smiles>C1CC2CCC12</smiles>
unhappy with themselves Bur pleased with themselves.<smiles>C1CCC1</smiles><smiles>C1CC2CCC12</smiles>

Some kids feel like they are just as smart as other kids their age BuT

Other kids aren't so sure<smiles>C1CCC1</smiles><smiles>C1CCC1</smiles>
and wonder if they are as smart. 
$\begin{array}{cc}\text { Really } & \text { Sort of } \\ \text { True } & \text { Truc }\end{array}$

(8)

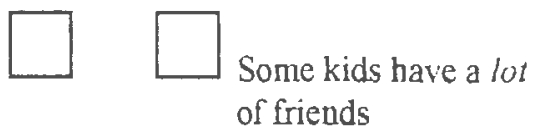

(9)

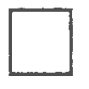

$\square$

Some kids wish they could be a lot better at BUT sports

(10)<smiles>C1CCC1</smiles><smiles>C1=CCC1</smiles>

Some kids are happy with their height and weight

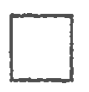

$\square$

Some kids usually do the right thing

Other kids often don't BCT do the right thing
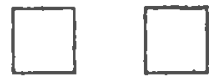
good enough at sports.

BLT

Other kids wish their
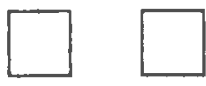
different.

(12)<smiles>C1=CCC1</smiles><smiles>C1=CCC1</smiles>

Some kids don't like the way they are leading their life

BU:T

Other kids do like the
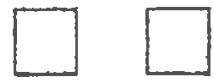
their life.<smiles>C1CC2CC12</smiles><smiles>C1CCC1</smiles>

Some kids are pretty slow finishing their school work.<smiles>C1CCC1</smiles><smiles>C1=CC=C1</smiles>

Some kids would like to have a lot more friends BliT

Other kids have as many

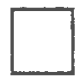
friends as they want.
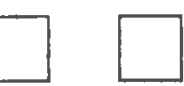

Other kids don't have BeT very many friends.
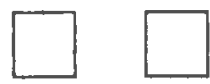

ther kids can do their
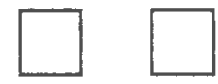

BLT school work quickly.
Other kids feel they are

Sort of Really

True True

80

for me for me
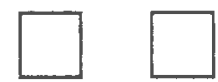
could do well at just about any new sports activity they haven't tried before

BLT they might not do well at sports they haven't ever tried.

Other kids like their
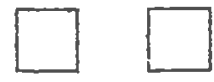
BIT body the way it is. 
Really Sort of

True Truc

for me for me

(17)<smiles>C1CCC1</smiles>

$\square$

Some kids usually act the way they know they are suppose to<smiles>C1CCC1</smiles><smiles>C1=CCC1</smiles>

Some kids often forget what they learn

Some kids are happy with themselves as a person ElT happy with themselves.

(20)<smiles>C1CCC1</smiles><smiles>C1=CCC1</smiles>

Sorne kids are always doing things with a lot BLT of kids<smiles>C1CCC1</smiles><smiles>C1=CCC1</smiles>

Some kids feel that they are better than others Bt? $T$ their age at sports<smiles>C1CCC1</smiles><smiles>C1=CCC1</smiles>

Some kids wish their physical appearance (how they look) was different<smiles>C1CCC1</smiles><smiles>C1=CCC1</smiles>
Some kids usually get in trouble because of things they do<smiles>C1CCC1</smiles><smiles>C1CCC1</smiles>

Sorne kids like the kind of person thcy are BUT

Other kids can
Other kids usually do things by themselves.

Other kids don't feel they can play as well.

Sort of Really

True True

for me for me

Other kids often don't
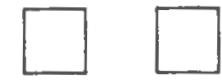

Bl'r act the way they are

suppose to.

Other kids are often not
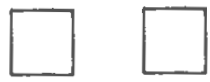

$\mathrm{BL} \mathrm{T}$ remember things easily.
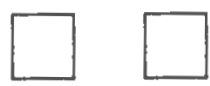
$\begin{array}{cc}\text { Really } & \text { Sort of } \\ \text { True } & \text { True } \\ \text { for nie } & \text { for me }\end{array}$

(26)

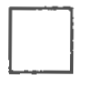

$\square$

Some kids wish that more people their age liked them

(27)<smiles>C1C2CC12</smiles><smiles>C1CCC1</smiles>

In games and sports sone kids usually watch BUT rather than just watch. instead of play

(28)
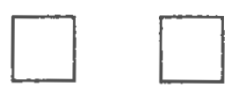

Some kids wish something about their Blit face or hair looked different<smiles>C1CC2CC12</smiles><smiles>C1=CCC1</smiles>

Some kids do things they know they shouldn't do<smiles>C1=CCC1</smiles><smiles>C1=CCC1</smiles>

Some kids are very happy being the way they are
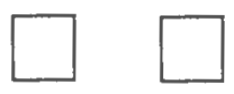

Some kids have trouble figuring out the answers BLT in school
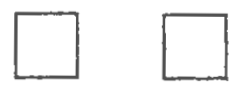

Some kids are popular with others their age<smiles>C1=CCC1</smiles><smiles>C1=CCC1</smiles>

Some kids don't do well at new outdoor games BUT

Other kids are good at

Other kids almost

Sort of Really

True True

for me for me

Other kids feel that most
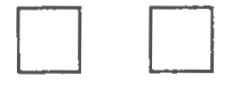

BLT them.

Other kids usually play
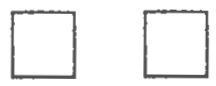

Other kids like their face
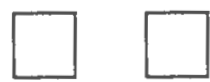
and hair the way they' are.

BUT

Other kids hardly ever<smiles>C1CC2CCC12</smiles><smiles>C1CC2CC12</smiles>
they shouldn't do.

Other kids wish they<smiles>C1=CCC=1</smiles><smiles>C1CCC1</smiles>
BuT were different.

alwaus can figure out the answers.

Other kids are not very<smiles>C1CCC1</smiles><smiles>C1CCC1</smiles>
BLT popular.<smiles>C1=CCC1</smiles>

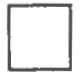

Some kids think that

Other kids think that
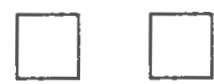
they are good looking BL:T they are not very good looking. 
Really Sort of

True True

forme forme

(35)<smiles>C1CC2CC12</smiles><smiles>C1=CCC1</smiles>

Some kids behave themselves very well

(36)<smiles>C1CCC1</smiles><smiles>C1CC2CCC12</smiles>

Some kids are not very happy with the way they do a lot of things

Sort of Really 83

True True

for me for me

Other kids often find it<smiles>C1CC2CC12</smiles>

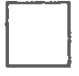

BuT hard to behave themselves.

Other kids think the way

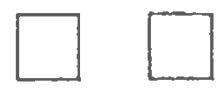
BuT they do things is fine. 
Appendix D

April 30, 1993

Dear Parent(s):

I am currently in the process of completing the requirements for my Ph.D. in psychology at the University of Rhode Island. I have completed all of my course work, internship experiences and examinations and now have begun to assimilate my dissertation proposal. As you know, I have been working at the J.W. Killam School as the School Psychologist for three-years.

As a doctoral level student, my primary goal is to learn how to effectively design and implement important research projects that are valuable to the schools. One area that I have been interested in is how boys and girls develop their ideas about future career choices. We know that children begin to formulate their ideas before reaching elementary school. I am interested in providing children will an opportunity to be exposed to many different types of careers, so that they become aware of the vast diversity of opportunities available to them.

I have planned a program that will begin within the next two weeks. Shortly you will be receiving information about the study and a parental consent form for your child to participate. I encourage your cooperation in this project, as I feel the results will add to our understanding about boys' and girls' attitudes about adult work.

In order to be assured of the effectiveness of this program, I would ask you to please not discuss the purpose of this study with your child for the time being. It is important that an understanding of the children's current perceptions about adult careers are being measured.

Thank you for your consideration in this matter. I look forward to your response.

Sincerely,

Deborah M. Dutton, Med

J.W. Killam School Psychologist

Doctoral Candidate $(\mathrm{PhD})$ at the University of Rhode Island 
Appendix E

May 3, 1993
Dear Parent(s):

Enclosed is a consent form for your child to participate in the research project I have recently told you about. The consent form is a formal requirement by the University of Rhode Island.

Throughout this research project, I will make every effort to ensure that the program is comfortable and enjoyable for all those participating and will remain sensitive to any concerns that your child might have. The decision not to participate will not penalize me or my child in any way.

Thank you for your time.

Sincerely,

Deborah M. Dutton

J.W. Killam School Psychologist 


\title{
Appendix F
}

\author{
The University of Rhode Island \\ Department of Psychology \\ Chafee Social Science Center \\ Kingston, RI 02881
}

Evaluating the Effectiveness of a School-Based Program:

Girls' and Boys' Understanding of Adult Careers

CONSENT FORM FOR RESEARCH

My child has been asked to take part in a research project described in detail below. If I have questions now or later, I should feel free to contact the person mainly responsible for this study, Deborah Dutton, 944-7831.

Description of the project:

My child has been asked to take part in the study which will evaluate the effectiveness of a school-based program designed to stimulate children's understanding about adult careers.

What will be done:

If I decide to allow my child to take part in this study here is what will happen: The child will be asked to complete two inventories found to be related to adult careers (younger children will receive adult assistance). At this juncture, a random sample of students will participate in a program about adult careers. To stimulate thinking about work, short stories will be read (fiction and non-fiction) and discussion about story characters will follow. A panel discussion, composed of men and women in different careers, will be presented in which the workers will describe their work experience, salary and job requirements. A question and answer session will follow. After the sessions are conducted, all children will be asked to complete an inventory about what they think about themselves and what they do well. The study will take place in five 30-45 minute sessions in the course of one week. Then your child will complete the inventory again to evaluate the long-term effects of the program.

Some of the group will be interviewed about what they know regarding adult careers and what they think they would like to do for work when they grow up. The interview will last for approximately 15 minutes and will be audiotaped and transcribed.

The study will be conducted much like other activities performed in the classroom and presents minimal risks to your child.

The proposed program will be made available to other students in the June of 1993.

The information obtained from your child is confidential. None of the information will identify your child by name, rather a number will be assigned to each child's file. All 
records will be kept in a locked file cabinet in the school psychologist's office. Audiotapes will be transcribed and erased.

The decision whether or not to take part in this study is up to me as parent. As mentioned in my letter, my child does not have to participate. If I decide to allow my child to take part in the study, he or she may quit at any time. Whatever I decide will in no way penalize my child. If I want my child or my child wants to quit I simply inform Deborah Dutton (944-7831) of my decision.

If I have any questions or concerns about the study, I may discuss them with Deborah Dutton or with Dr. Denise DeZolt (401) 792-4221, anonymously, if I choose. In addition, I may contact the Office of the Vice Provost for Research, 70 Lower College Road, University of Rhode Island, Kingston, Rhode Island, telephone: (401) 792-2635.

Programs regarding adult careers have been shown to have positive effects on children's understanding and attitudes about work. In addition, it is hoped that this study will make a significant contribution to the research literature about career development. I have read the Consent Form. My questions have been answered. My signature on this form means that I understand the information and agree for my child to participate in this study.

Parent Signature

Typed/Printed Name
Signature of Researcher

Typed/Printed Name 
Appendix G

\section{EVALUATING THE EFFECTIVENESS OF A SCHOOL-BASED PROGRAM: CHILDREN'S UNDERSTANDING OF ADULT WORK}

$\mathrm{Hi}$ My name is Ms. Dutton and I am trying to learn more about what girls and boys know about adult work. I want you to tell me what kinds of jobs you would like to do when you grow-up, how you feel about yourself and what things you do well. I also want to know what you think about the kinds of work men and women do. You will be listening to stories, sharing ideas with your classmates and listening to a group of women and men talk about their work.

What you tell me will be kept confidential, that means that $I$ will not share this information with anyone. Your name will not be on any of the forms and I will lock all of the information up in a file drawer in my office.

Do you want to do this? $\quad$ YES NO

Do you have any questions for me? YES NO

If you want to stop at any time just tell me.

Student's Signature

Date

I have witnessed the consent process and believe that the person listed above has been fully informed, understands the project and his or her role and has voluntarily agreed to participate.

Witness' Signature

Date 
Girls and Boys Understanding About Adult Careers

I agree to audiotaping at the J.W. Killam School at on

Signature Date

I have been told that I have the right to hear the audiotapes before they are used. I have decided that I:

want to hear the tapes do not want to hear the tapes

Sign now below if you do not want to hear the tapes. If you want to hear the tapes, you will be asked to sign after hearing them.

Deborah Dutton and other approved researchers may/may not use the tapes made of me. The original tapes or copies may be used for:

this research project ___teacher education __ presentation at professional meetings

Signature

Date 
Appendix $\mathrm{H}$

\section{EVALUATING THE EFFECTIVENESS OF A SCHOOL-BASED \\ PROGRAM: GIRLS' AND BOYS' UNDERSTANDING \\ OF ADULT WORK}

I want to know more about how girls and boys of different ages understand adult careers. I am interested in what kinds of jobs boys and girls are interested in doing when they get older. I want to know what children think about themselves and how this relates to the types of jobs they want to have as an adult. If you agree to do this, we'll begin by completing some forms about how you feel about yourself and your skills and I will ask you to tell me about the kinds of jobs that you would like to do as an adult. One the next day, we will be imagining what it would be like to be an adult worker. The next time we will listen to stories about men and women workers and talk about their jobs. Then a group of men and women will come in to talk to us about their jobs and we will have a chance to ask questions about their work. This will all take place within a one week period, approximately 30-45 minutes each session. Some of you will also come to see me in my office to talk about what kinds of work you would like to do and why. This will take about 15 -minutes. Then I'll meet with you about 30 minutes and I'll ask you again to answer some questions about yourself and what you would like to do when you grow-up.

Whatever you put on the forms will be kept confidential. Also, whatever you talk with me about in my office will be confidential -it won't be shared with anyone else. The information you provide will be assigned a number and will be kept in a locked file cabinet in my office, your name will not be on the forms. 
If you take part in this project, you will be helping teachers and others to know more about what girls and boys think about adult careers. Taking part in this project is entirely up to you, an no one will hold it against you if you decide not to do it. If you do take part you may stop at any time.

If you want to know more about this project, feel free to make an appointment to see me. This project has been approved by the University of Rhode Island.

There are two copies of this consent form. One is for you to keep and the other will be turned in to me.

Sincerely,

Deborah M. Dutton

J.W. Killam School Psychologist

I agree to take part in this project. I know what I will have to do and that I can stop at any time.

$\overline{\text { Signature } \quad \text { Date }}$

\section{ASSENT FOR AUDIOTAPING SESSION}

I agree to audiotaping at the J.W. Killam School at on

Signature

Date

I have been told that I have the right to hear the audiotapes before they are used. I have decided that I:

Want to hear the tapes Do not want to hear the tapes 
Appendix I

\section{A Childhood Dream Comes True \\ by Deborah M. Dutton}

The ferry ride was long and Mike Shields could not wait to arrive at Mohegan Island. Maine was by far his favorite place to be. As a child, he had spent almost all of his summers away from home at Camp Elk where he had learned to appreciate the wilderness. He loved seeing the deer run at dusk near the waterfront, through the trees, onto places that he could only imagine about. At Elk he first learned to fish, kayak, play baseball, basketball and tennis, sing camp songs and learn about other children.

He remembered all of these things as he journeyed across Christmas Cove on route to Mohegan. This was his first job as an elementary school teacher. Many people were interviewed for the position, but Mike was hired because of the enthusiasm he had about working with kids, his love for Maine and the wilderness and because he was so wellprepared to a good job as a teacher.

He looked over to the side of the boat and saw a lobster fisherman pulling in a trap and again his mind wandered to days before. He had just graduated with honors from Dartmouth University. There, he raced down the Connecticut River with the crew team, played football with his friends at Adams House and in the spring, played shortstop for the baseball team. Those were the days that his father wanted him to go on to the business school. He wanted him to follow in his footsteps and run corporate finances. His mother wanted him to become a concert pianist and to go to Paris to study music. His grandmother wanted him to be a lawyer, just like his grandfather. He laughed when 
he though about it. He chuckled aloud and the passenger across from him gave him an odd grin and continued to read his newspaper.

The captain blew the horn and Mike jumped a little. He knew that he would be arriving shortly and his energy level increased. A sail boat passed by and waved to the passengers on the ferry. Mike began to think about how he came to want to be an elementary school teacher. Oh yes, Camp Elk again.

Nancy and Bill Morris were the camp directors in those days. They were both school teachers in Newton, Massachusetts. They talked to the campers during meals at the mess hall. Bill told stories about the kids in his classes, the funny stories, the sad stories about how difficult it was for some children to learn and how important it was that all children receive a good education. Bill liked kids, that was for sure and he liked his job. Mike and Bill became good friends during those summer days and Bill taught Mike how to teach young children. Bill taught them how to be a good sport, how to try as hard as you could when you were playing ball or learning to swim. Mike learned a lot about children from Bill.

Nancy was a good athlete. She would take time to play tennis and basketball with some of the boys and ask them about how they were doing in school. She talked about how important her teaching job was, how teaching children to read, write and do mathematics would make a difference for their whole life. Mike liked that, making a difference.

The ferry was getting closer to land. Mike could see the pine trees reach high above the rocks on the coast of Mohegan Island. He looked forward to fishing on 
Saturdays, chopping trees for firewood in the winter, playing the piano in the evenings and watching the deer race across the fields at dusk. Monday he would begin his first job as an elementary school teacher in a small school in the village. There would be fifteen children in his classroom ages five to eight. That would be a challenge. He would teach them how to read, write and do mathematics. All in all his family would come to see that his job was very important. He would teach the children music and about the piano, he would teach them math skills and he would teach them how to be honest and fair. His life on Mohegan Island was about to begin. He was excited, he would make a difference. 
Appendix J

\section{Guided Discussion Questions}

Focus on the story in a depersonalized manner.

Reconstruct the story (characters, events).

Who were the characters?

What happened in the story?

Identify feelings and behavior of characters.

How do you think she/he was feeling? How could you tell?

What did she/he do?

Identify alternative behaviors.

What would happen if...?

How else could she/he have handled the situation?

Focus on real-life experiences in a personalized manner.

How does this relate to your own experiences?

Have you ever encountered anything like this?

How did you feel?

What did you do?

$\underline{\text { Summary }}$

What was the problem the character encountered, or the goal the character was trying to reach?

How effective were the character's strategies for solving the problem, or reaching the goal?

What might you do in the future in a similar situation? 
Appendix K

\section{STANDARDIZED INTERVIEW}

1.) Name three jobs that you would like to do as an adult:

a.)

b.)

c.)

2.) What is it about the job that makes you want to do it? JOB A:

JOB B:

JOB $\mathrm{C}$ :

3.) What would you have to be good at to do this job? JOB A:

JOB B:

JOB C:

4.) How do you plan to do this?

5.) Who do you know who has these jobs?

JOB A:

JOB B:

JOB C:

6.) What jobs do you think a G/B would pick? Why? 
Appendix L

DIRECTIONS: Please rate the following jobs according to whether they are STEREOTYPIC masculine, feminine or gender neutral.

$\begin{array}{lll}1 & 2 & 3 \\ \text { FEMININE } & \text { NEUTRAL } & \text { MASCULINE }\end{array}$

1.) — ACTRESS

2.) — ARCHEOLOGIST

3.) — ARCHITECT

4.) — ARTIST

5.) — ASTRONAUT

6.) — BAKER

7.) — BASEBALL CARD MAKER

8.) — BASEBALL PLAYER

9.) — BASKETBALL PLAYER

10.) — BRAIN SURGEON

11.) — BUS DRIVER

12.) — BUSINESSMAN

13.) — CAMP LODGE OWNER

14.) - CAR MECHANIC

15.) — CARPENTER

16.) - CASHIER

17.) — CHIROPRACTOR

18.) — CLERK

19.) — COMEDIAN

20.) — COMPUTER PROGRAMMER

21.) — CONSTRUCTION WORKER

22.) — CONSULTANT

23.) — CYBERNETICIST

24.) - DANCER

25.) - DAY CARE WORKER

26.) — DENTAL HYGIENIST

27.) — DENTIST

28.) — DOCTOR

29.) — DOLPHIN TRAINER

30.) — ELECTRICAL ENGINEER

31.) — ELECTRICIAN

32.) — ENGINEER

33.) — FAMILY THERAPIST

34.) — FASHION DESIGNER

35.) — FIGURE SKATER

35.) — FIREMAN

36.) — FBI AGENT

37.) — FOREST RANGER

38.) — GYMNAST

39.) — HAIR STYLIST

40.) — HELP HANDICAPPED KIDS
41.) — HOCKEY PLAYER

42.) — HOUSE KEEPER

43.) — JUDGE

44.) — LAWYER

45.) — LIBRARIAN

46.) — MARINE BIOLOGIST

47.) — MECHANICS/MAKE ROBOTS

48.) — MOTHER

49.) — MUSEUM WORKER

50.) — NEWSCASTER

51.) — NEWS REPORTER

52.) — NURSE

53.) — PAINTER

54.) — PET SHOP WORKER

55.) — PHOTOGRAPHER

56.) — PILOT

57.) — POLICE OFFICER

58.) — PRESDENT

60.) — PROFESSIONAL ATHLETE

61.) — RANGER

62.) — RESTAURANT COOKER

63.) — ROCK AND ROLL SINGER

64.) — SECRETARY

65.) — SCIENTIST

66.) — SINGER

67.) — SOCCER PLAYER

68.) — SPORTS PLAYER

69.) — STORE MANAGER

70.) — SWIMMER

71.) — TAXI DRIVER

72.) — TEACHER

73.) — TENNIS PLAYER

74.) — THERAPIST

75.) — TRASH MAN

76.) — TRUCK DRIVER

77.) — VETERINARIAN

78.) — VIDEO GAMES-MAKER

79.) — WAITRESS

80.) — WORK/A DRIVE-IN WINDOW

81.) — WRITER

82.) — ZOOKEEPER 
Appendix M

CODING SCHEME FOR QUALITATIVE ANALYSIS

\section{Interview Question 1}

Name three jobs you would like to do as an adult?

$1=$ Stereotypic feminine career

$2=$ Stereotypic gender neutral career

$3=$ Stereotypic masculine career

$5=$ Missing 
Appendix N

CODING SCHEME FOR QUALITATIVE ANALYSIS

\section{Interview Question 2}

What is it about the job that makes you want to do it?

$1=$ Helping/caring/nurturing

$2=$ Constructing/building/mechanical/technical

$3=$ Powerful role/decision making/high income/law enforcement

$4=$ Intellectual interest

$5=$ Entertaining/performing

$6=$ Creativity

$7=$ Competition

$8=$ Adventure

$9=$ Other

$10=$ Physical

$11=$ Positive esteem, "I'm good at it."

$12=$ Enjoyment

$13=$ Socialization/like to be with people

$14=$ Independence

$19=$ Missing

\section{Recoding Scheme}

$1=$ Helping/caring/nurturing/socializing (Codes $1 \& 13$ )

$2=$ Constructing/building/mechanical/technical

$3=$ Powerful role/decision making/high income/law enforcement

$4=$ Intellectual interest

$5=$ Entertaining/performing/creativity (Codes $5 \& 6$ )

$7=$ Competition/adventure/physical/independence (Codes 7,8,10, \& 14)

$9=$ Other

$11=$ Positive esteem, "I'm good at it."

$12=$ Enjoyment

$19=$ Missing 
Appendix $\mathrm{O}$

\section{CODING SCHEME FOR QUALITATIVE ANALYSIS}

\section{$\underline{\text { Interview Question } 3}$}

What would you have to be good at to do this job?

$1=$ Intellectual/knowledge/learning

$2=$ Skill development (i.e., being good at a specific skill)

$3=$ Caring/nurturing

$4=$ Instructing

$5=$ Problem solving

$6=$ Science $/$ math

$7=$ Creativity

$8=$ Procedural (i.e., basic skill)

$9=$ Other

$13=$ Athletic

$19=$ Missing

\section{$\underline{\text { Recoding Scheme }}$}

$1=$ Intellectual/knowledge/learning/problem solving/science \& math (Codes $1,5, \& 6)$

$2=$ Skill development (i.e., being good at a specific skill)

$3=$ Caring/nurturing/instructing (Codes $3 \& 4)$

$7=$ Creativity

$8=$ Procedural (i.e., basic skill)

$9=$ Other

$19=$ Missing 
Appendix P

CODING SCHEME FOR QUALITATIVE ANALYSIS

\section{Interview Question 4}

How do you plan to do this?

$1=$ Formal education (e.g., college)

$2=$ Skill training (e.g., vocational training)

$3=$ On the job training

4= Practice skill

5= Apprentice (i.e., observe/practice)

$6=$ Become credentialed

$7=$ Attitude (e.g., work hard)

$8=$ Creativity (i.e., think of ideas, etc. independently)

$9=$ Other

$19=$ Missing

\section{Recoding Scheme}

$1=$ Formal education (e.g., college)

$2=$ Skill training (e.g., vocational training)

$3=$ On the job training/practice skill/apprentice (Code 3, 4, \& 5)

$7=$ Attitude (e.g., work hard)

$9=$ Other $($ Codes $6,8, \& 9)$

$19=$ Missing 
Appendix Q

\section{CODING SCHEME FOR QUALITATIVE ANALYSIS}

\section{Interview Question 5}

$$
\begin{aligned}
& 1=\text { Female relative } \\
& 2=\text { Male relative } \\
& 3=\text { Teacher } \\
& 4=\text { Professional athlete } \\
& 5=\text { Parents' friend } \\
& 6=\text { Professional performer } \\
& 7=\text { No one } \\
& 8=\text { Don't know } \\
& 9=\text { Other } \\
& 19=\text { Missing }
\end{aligned}
$$

Who do you know who has these jobs?

$\underline{\text { Recoding Scheme }}$

$1=$ Male relative

$2=$ Female relative

$3=$ Teacher

$4=$ Professional athlete/professional performer (Codes 4 \& 6)

$7=$ No one/don't know (Codes 7 \& 8)

$9=$ Other $($ Codes $5 \& 9)$

$19=$ Missing 
Appendix R

\section{CODING SCHEME FOR QUALITATIVE ANALYSIS}

\section{Interview Question 6}

Name three jobs you think a boy/girls would choose (i.e., person of the opposite sex)?

$1=$ Stereotypic feminine career

$2=$ Stereotypic gender neutral career

$3=$ Stereotypic masculine career

$4=$ Any job they want

$5=$ Missing

$6=$ Unsure 
Appendix S

\section{CODING SCHEME FOR QUALITATIVE ANALYSIS}

\section{$\underline{\text { Interview Question } 7}$}

[RE: JOB OPPOSITE SEX WOULD CHOOSE] What is it about that job that you think a $\mathrm{B} / \mathrm{G}$ would like?

$1=$ Intellectual/knowledge/learning

$2=$ Skill development (i.e., being good at a specific skill)

$3=$ Caring/nurturing

4= Instructing

$5=$ Problem solving

$6=$ Science/math

$7=$ Creativity

$8=$ Procedural (i.e., basic skill)

$9=$ Other

$10=$ Helper

$11=$ Hard working

$12=$ Any job they feel like

$13=$ Athletic

$14=$ Powerful role/higher income

$15=$ Competitive

$16=$ Physical/working with hands

$17=$ Enjoyment

$18=$ Only see that sex doing that job

$19=$ Missing

\section{$\underline{\text { Recoding Scheme }}$}

1= Intellectual/knowledge/learning/problem solving/science \& math (Codes $1,5, \& 6)$

$2=$ Skill development (i.e., being good at a specific skill)

$3=$ Caring/nurturing/instructing/helper (Codes 3,4, \& 10)

$7=$ Creativity

$8=$ Procedural (i.e., basic skill)

$9=$ Other Codes $9,11, \& 17)$

$12=$ Any job they feel like

$13=$ Athletic/powerful role/higher income/competitive/ physical/working with hands

$18=$ Only see that sex doing that job

$19=$ Missing 
Table 14

Appendix T

Test-Retest Reliability Estimate for all Dependent Measures on Control Group Correlations Between Pre-test and Post-test $(\mathrm{N}=40)$

Dependent Measure

Correlation Coefficient

Occupational Choice Survey

$0.78 * * *$

You-Masculine

$0.74 * * *$

You-Feminine

$0.79 * * *$

You-Neutral

$0.79 * * *$

Man-Masculine

$0.64 * * *$

Man-Feminine

$0.62 * * *$

Man-Neutral

$0.72 * * *$

Woman-Masculine

$0.66^{* * *}$

Woman-Feminine

$0.53 * * *$

Woman-Neutral

$0.73 * * *$

CSRI-Masculine

$0.46^{* * *}$

CSRI-Feminine

$0.75 * * *$

P.C.-Scholastic

$0.83 * * *$

P.C.-Social

$0.77 * * *$

P.C.-Athletic

$0.85 * * *$

P.C.-Physical

$0.79 * * *$

P.C.-Behavioral

$0.75^{* * *}$

P.C.-Global

$0.72 * * *$

${ }^{*} \mathrm{p} \leq .10 * * \mathrm{p} \leq .05 * * * \mathrm{p} \leq .01$ 
Table 15

Pretest Equivalence Analysis of Intervention vs Control Condition on Dependent Measures $(2 \times 2 \times 2)$ ANOVA (Gender $\times$ Grade $\times$ Intervention)

\begin{tabular}{lcl} 
Dependent Variables $^{\mathrm{a}}$ & $\underline{\mathrm{F}}$ & $\mathrm{p}$ \\
\hline Job Choice & 1.53 & .22 \\
You- Masculine & 0.12 & .73 \\
You-Feminine & 0.47 & .50 \\
You-Neutral & 2.96 & $.09^{*}$ \\
Man-Masculine & 0.07 & .79 \\
Man-Feminine & 0.99 & .32 \\
Man-Neutral & 0.10 & .76 \\
Woman-Masculine & 0.18 & .68 \\
Woman-Feminine & 0.01 & .92 \\
Woman-Neutral & 0.79 & .38 \\
CSRI-Masculine & 1.43 & .24 \\
CSRI-Feminine & 0.02 & .89 \\
P.C. -Scholastic & 2.54 & .17 \\
P.C.-Social & 1.20 & .28 \\
P.C.-Athletic & 0.18 & .67 \\
P.C.-Physical & 0.88 & .35 \\
P.C.-Behavioral & 0.01 & .91 \\
P.C.-Global & 3.24 & $.08 *$ \\
T. & &
\end{tabular}

${ }^{a}$ Refer to Chapter II for explanation of Dependent Variable.

${ }^{\mathrm{b}} \mathrm{P} . \mathrm{C} .=$ Perceived Competence.

$* \mathrm{p} \leq .10 * * \mathrm{p} \leq .05 * * * \mathrm{p} \leq .01$ 
Table 16

Pretest Equivalence Analysis of Grades 2 vs 5 (ANOVA) on all Dependent Measures $(2 \times 2 \times 2)$ ANOVA (Gender $\times$ Grade $\times$ Intervention)

\begin{tabular}{lll} 
Dependent Variable & $\underline{\mathrm{F}}$ & $\mathrm{p}$ \\
\hline Job Choice & 00.24 & .63 \\
You- Masculine & 03.18 & $.08^{*}$ \\
You-Feminine & 19.38 & $.01^{* * *}$ \\
You-Neutral & 53.60 & $.01^{* * *}$ \\
Man-Masculine & 01.62 & .21 \\
Man-Feminine & 01.02 & .32 \\
Man-Neutral & 06.74 & $.01^{* * *}$ \\
Woman-Masculine & 09.79 & $.01^{* * *}$ \\
Woman-Feminine & 01.39 & .24 \\
Woman-Neutral & 00.08 & .79 \\
CSRI-Masculine & 00.76 & .39 \\
CSRI-Feminine & 00.01 & .91 \\
P.C. ${ }^{2}-$ Scholastic & 02.00 & .16 \\
P.C.-Social & 00.85 & .36 \\
P.C.-Athletic & 00.09 & .76 \\
P.C.-Physical & 00.15 & .70 \\
P.C.-Behavioral & 00.47 & .50 \\
P.C.-Global & 00.41 & .52 \\
a P.C.= Perceived Competence. & & \\
* p $\leq .10 * *$ p $\leq .05 * * \mathrm{p} \leq .01$ & &
\end{tabular}


Table 17

Pretest Equivalence Analysis of Gender on all Dependent Measures $(2 \times 2 \times 2)$ ANOVA (Gender $\times$ Grade $\times$ Intervention)

\begin{tabular}{|c|c|c|}
\hline Dependent Variables & $\underline{\mathrm{F}}$ & $\mathrm{p}$ \\
\hline Job Choice & 43.27 & $.01 * * *$ \\
\hline You- Masculine & 10.65 & $.01 * * *$ \\
\hline You-Feminine & 23.48 & $.01 * * *$ \\
\hline You-Neutral & 00.08 & .78 \\
\hline Man-Masculine & 00.08 & .77 \\
\hline Man-Feminine & 01.95 & .17 \\
\hline Man-Neutral & 07.17 & $.01 * * *$ \\
\hline Woman-Masculine & 00.24 & .63 \\
\hline Woman-Feminine & 00.01 & .99 \\
\hline Woman-Neutral & 00.13 & .72 \\
\hline CSRI-Masculine & 02.53 & .12 \\
\hline CSRI-Feminine & 19.65 & $.01 * * *$ \\
\hline P.C. ${ }^{\text {a }}$ Scholastic & 04.51 & .037 \\
\hline P.C.-Social & 02.29 & .13 \\
\hline P.C.-Athletic & 12.00 & $.01 * * *$ \\
\hline P.C.-Physical & 00.58 & .45 \\
\hline P.C.-Behavioral & 10.89 & $.01 * * *$ \\
\hline P.C.-Global & 03.18 & .08 \\
\hline
\end{tabular}


Table 18

Means and Standard Deviations and $(\mathrm{N})$ for Children's Perception of Future Occupational Choices for "Self" at Pre-test and Post-test by Grade, Gender, \& Treatment Group

\begin{tabular}{|c|c|c|c|c|c|}
\hline & & & ention & Contro & \\
\hline & & Pre-test & Post-test & Pre-test & Post-test \\
\hline Grade 2 & & & & & \\
\hline Boys & M & $3.43(7)$ & $3.86(7)$ & $3.70(10)$ & $3.50(10)$ \\
\hline & SD & 1.13 & 1.07 & 0.82 & 0.53 \\
\hline Girls & M & $4.92(12)$ & $5.50(12)$ & $5.33(9)$ & $5.89(9)$ \\
\hline & SD & 1.83 & 1.62 & 1.66 & 2.03 \\
\hline Grade 5 & & & & & \\
\hline Boys & M & $3.33(9)$ & $5.00(9)$ & $3.30(10)$ & $3.50(10)$ \\
\hline & SD & $(.05)$ & 1.67 & 0.67 & 0.85 \\
\hline Girls & M & $5.27(10)$ & $6.20(10)$ & 5.91 & $6.27(11)$ \\
\hline & SD & 1.35 & 1.32 & 1.51 & 1.74 \\
\hline
\end{tabular}


Table 19

Means and Standard Deviations and $(\mathrm{N})$ for Children's Perception of Future Occupational Choices in Traditional Stereotypic Masculine Career for "Self" at Pre-test and Post-test by Grade, Gender, \& Treatment Group

\begin{tabular}{|c|c|c|c|c|c|}
\hline & & \multicolumn{2}{|c|}{ Intervention } & \multicolumn{2}{|c|}{ Control } \\
\hline & & Pre-test & Post-test & Pre-test & Post-test \\
\hline \multicolumn{6}{|c|}{ Grade 2} \\
\hline \multirow[t]{2}{*}{ Boys } & $\mathbf{M}$ & $12.71(7)$ & $12.29(7)$ & $16.40(10)$ & $15.00(10)$ \\
\hline & SD & 5.51 & 5.26 & 4.12 & 4.40 \\
\hline \multirow[t]{2}{*}{ Girls } & $\mathbf{M}$ & $10.25(12)$ & $12.08(12)$ & $9.56(9)$ & $9.78(9)$ \\
\hline & SD & 3.79 & 3.29 & 3.43 & 3.27 \\
\hline \multicolumn{6}{|c|}{ Grade 5} \\
\hline \multirow[t]{2}{*}{ Boys } & $\mathbf{M}$ & $12.71(9)$ & $13.33(9)$ & $9.70(10)$ & $11.10(10)$ \\
\hline & SD & 5.51 & 2.29 & 3.13 & 3.38 \\
\hline \multirow[t]{2}{*}{ Girls } & $\mathbf{M}$ & $10.91(10)$ & $11.90(10)$ & $9.82(11)$ & $10.82(11)$ \\
\hline & $\mathrm{SD}$ & 3.53 & 3.35 & 3.34 & 3.40 \\
\hline
\end{tabular}


Table 20

Means and Standard Deviations and (N) for Children's Perception of Future Occupational Choices for Stereotypic Feminine Careers for "Self" at Pre-test and Posttest by Grade, Gender, \& Treatment Group

\begin{tabular}{|c|c|c|c|c|c|}
\hline & & \multicolumn{2}{|c|}{ Intervention } & \multicolumn{2}{|c|}{ Control } \\
\hline & & Pre-test & Post-test & Pre-test & Post-test \\
\hline \multicolumn{6}{|c|}{ Grade 2} \\
\hline \multirow[t]{2}{*}{ Boys } & $\mathbf{M}$ & $7.86(7)$ & $8.29(7)$ & $10.60(10)$ & $11.60(10)$ \\
\hline & $\mathrm{SD}$ & 2.19 & 2.50 & 4.88 & 5.38 \\
\hline \multirow[t]{2}{*}{ Girls } & $\mathbf{M}$ & $13.75(12)$ & $15.92(12)$ & $14.44(9)$ & $13.11(9)$ \\
\hline & $S D$ & 3.86 & 4.14 & 5.85 & 4.59 \\
\hline \multicolumn{6}{|c|}{ Grade 5} \\
\hline \multirow[t]{2}{*}{ Boys } & $\mathbf{M}$ & $7.33(9)$ & $8.44(9)$ & $7.00(10)$ & $7.30(10)$ \\
\hline & $\mathrm{SD}$ & 1.12 & 1.88 & 1.41 & 1.83 \\
\hline \multirow[t]{2}{*}{ Girls } & $\mathbf{M}$ & $10.09(11)$ & $10.50(10)$ & $9.73(11)$ & $11.00(11)$ \\
\hline & $\mathrm{SD}$ & 1.97 & 2.32 & 2.10 & 2.45 \\
\hline
\end{tabular}


Table 21

Means and Standard Deviations and ( $\mathrm{N}$ ) for Children's Perception of Future Careers on Stereotypic Gender Neutral Careers for "Self" at Pre-test and Post-test by Grade, Gender, \& Treatment Group

\begin{tabular}{cccccc}
\hline & \multicolumn{2}{c}{ Intervention } & \multicolumn{2}{c}{ Control } \\
& & Pre-test & Post-test & Pre-test & Post-test \\
\cline { 2 - 6 } & & & & & \\
Grade 2 & & & & 16.70 & $14.00(10)$ \\
Boys & M & $11.71(7)$ & $13.71(7)$ & 3.65 & 4.32 \\
& SD & 3.04 & 3.04 & & \\
Girls & M & $13.67(12)$ & $15.75(12)$ & $8.20(10)$ & $14.78(9)$ \\
& SD & 4.12 & 4.05 & 2.70 & 3.49 \\
& & & & & \\
Grade 5 & & & & & \\
Boys & M & $9.33(9)$ & $9.56(9)$ & $2.70(10)$ & $9.10(10)$ \\
& SD & 2.74 & 2.51 & & 3.07 \\
Girls & M & $9.18(10)$ & $10.50(10)$ & $9.91(11)$ & $10.82(11)$ \\
& SD & 1.99 & 2.22 & 2.66 & 3.09 \\
& & & & & \\
\hline
\end{tabular}


Table 22

Means and Standard Deviations and $(\mathrm{N})$ for Children's Perception of Stereotypic Masculine Careers for "Men" at Pre-test and Post-test by Grade, Gender, \& Treatment Group

\begin{tabular}{|c|c|c|c|c|c|}
\hline & & \multicolumn{2}{|c|}{ Intervention } & \multicolumn{2}{|c|}{ Control } \\
\hline & & Pre-test & Post-test & Pre-test & Post-test \\
\hline \multicolumn{6}{|c|}{ Grade 2} \\
\hline \multirow[t]{2}{*}{ Boys } & M & $19.00(7)$ & $21.43(7)$ & $21.90(10)$ & $20.90(10)$ \\
\hline & SD & 6.16 & 2.15 & 2.47 & 3.31 \\
\hline \multirow[t]{2}{*}{ Girls } & $\mathrm{M}$ & $20.75(12)$ & $20.58(12)$ & $21.44(9)$ & $20.22(9)$ \\
\hline & SD & 3.53 & 3.45 & 3.53 & 3.70 \\
\hline \multicolumn{6}{|c|}{ Grade 5} \\
\hline \multirow[t]{2}{*}{ Boys } & M & $21.33(9)$ & $19.33(9)$ & $18.70(10)$ & $19.40(10)$ \\
\hline & $\mathrm{SD}$ & 2.69 & 4.27 & 2.58 & 3.50 \\
\hline \multirow[t]{2}{*}{ Girls } & M & $19.91(11)$ & $18.36(11)$ & $20.09(11)$ & $20.18(11)$ \\
\hline & $\mathrm{SD}$ & 2.59 & 3.83 & 3.08 & 3.43 \\
\hline
\end{tabular}


Table 23

Means and Standard Deviations and $(\mathrm{N})$ for Children's Perception of "Men" in Stereotypic Feminine Careers at Pre-test and Post-test by Grade, Gender, \& Treatment Group

\begin{tabular}{|c|c|c|c|c|c|}
\hline & & \multicolumn{2}{|c|}{ Intervention } & \multicolumn{2}{|c|}{ Control } \\
\hline & & Pre-test & Post-test & Pre-test & Post-test \\
\hline \multicolumn{6}{|c|}{ Grade 2} \\
\hline \multirow[t]{2}{*}{ Boys } & $\mathrm{M}$ & $12.43(7)$ & $14.43(7)$ & $13.50(10)$ & $12.20(10)$ \\
\hline & $\mathrm{SD}$ & 2.15 & 3.69 & 4.20 & 3.68 \\
\hline \multirow[t]{2}{*}{ Girls } & $\mathbf{M}$ & $12.83(12)$ & $13.83(12)$ & $12.67(9)$ & $11.67(9)$ \\
\hline & $\mathrm{SD}$ & 2.37 & 2.76 & 2.29 & 1.73 \\
\hline \multicolumn{6}{|c|}{ Grade 5} \\
\hline \multirow[t]{2}{*}{ Boys } & $\mathbf{M}$ & $14.33(9)$ & $14.22(9)$ & $11.80(10)$ & $12.40(10)$ \\
\hline & $\mathrm{SD}$ & 5.43 & 4.47 & 1.62 & 2.63 \\
\hline \multirow[t]{2}{*}{ Girls } & $\mathbf{M}$ & $11.91(11)$ & $12.45(11)$ & $11.09(11)$ & $12.18(11)$ \\
\hline & $\mathrm{SD}$ & 2.76 & 2.62 & 2.55 & 4.26 \\
\hline
\end{tabular}


Table 24

Means and Standard Deviations and $(\mathrm{N})$ for Children's Perception of "Men" in Stereotypic Gender Neutral Careers at Pre-test and Post-test by Grade, Gender, \& Treatment Group

\begin{tabular}{|c|c|c|c|c|c|}
\hline & & \multicolumn{2}{|c|}{ Intervention } & \multicolumn{2}{|c|}{ Control } \\
\hline & & Pre-test & Post-test & Pre-test & Post-test \\
\hline \multicolumn{6}{|c|}{ Grade 2} \\
\hline \multirow[t]{2}{*}{ Boys } & $\mathrm{M}$ & $17.29(7)$ & $19.00(7)$ & $20.11(9)$ & $17.11(9)$ \\
\hline & $\mathrm{SD}$ & 1.98 & 1.83 & 2.89 & 4.31 \\
\hline \multirow[t]{2}{*}{ Girls } & $\mathrm{M}$ & $16.67(12)$ & $17.25(12)$ & $16.56(9)$ & $15.09(11)$ \\
\hline & SD & 2.31 & 3.11 & 3.05 & 3.56 \\
\hline \multicolumn{6}{|c|}{ Grade 5} \\
\hline \multirow[t]{2}{*}{ Boys } & $\mathrm{M}$ & $18.33(9)$ & $17.50(10)$ & $15.10(10)$ & $16.00(10)$ \\
\hline & SD & 4.30 & 3.72 & 2.13 & 2.71 \\
\hline \multirow[t]{2}{*}{ Girls } & M & $15.73(11)$ & $15.00(9)$ & $15.18(11)$ & $15.64(11)$ \\
\hline & SD & 2.83 & 3.32 & 4.14 & 4.76 \\
\hline
\end{tabular}


Table 25

Means and Standard Deviations and $(\mathrm{N})$ for Children's Perception of "Women" in Stereotypic Masculine Careers at Pre-test and Post-test by Grade, Gender, \& Treatment Group

\begin{tabular}{|c|c|c|c|c|c|}
\hline & & \multicolumn{2}{|c|}{ Intervention } & \multicolumn{2}{|c|}{ Control } \\
\hline & & Pre-test & Post-test & Pre-test & Post-test \\
\hline \multicolumn{6}{|c|}{ Grade 2} \\
\hline \multirow[t]{2}{*}{ Boys } & $\mathrm{M}$ & $9.17(7)$ & $13.14(7)$ & $12.20(10)$ & $12.80(10)$ \\
\hline & SD & 2.14 & 4.10 & 4.73 & 4.47 \\
\hline \multirow[t]{2}{*}{ Girls } & M & $10.42(12)$ & $12.92(12)$ & $11.11(9)$ & $11.33(9)$ \\
\hline & $\mathrm{SD}$ & 2.84 & 3.32 & 2.89 & 3.81 \\
\hline \multicolumn{6}{|c|}{ Grade 5} \\
\hline \multirow[t]{2}{*}{ Boys } & M & $14.22(9)$ & $14.57(9)$ & $12.70(10)$ & $13.50(10)$ \\
\hline & SD & 4.66 & 4.61 & 1.70 & 1.72 \\
\hline \multirow[t]{2}{*}{ Girls } & M & $14.36(11)$ & $14.55(11)$ & $12.00(11)$ & $12.45(11)$ \\
\hline & SD & 3.35 & 3.50 & 3.26 & 3.98 \\
\hline
\end{tabular}


Table 26

Means and Standard Deviations and $(\mathrm{N})$ for Children's Perceptions of "Women" in Stereotypic Feminine Careers at Pre-test and Post-test by Grade, Gender, \& Treatment Group by Grade, Gender, \& Treatment Group

\begin{tabular}{|c|c|c|c|c|c|}
\hline & & \multicolumn{2}{|c|}{ Intervention } & \multicolumn{2}{|c|}{ Control } \\
\hline & & Pre-test & Post-test & Pre-test & Post-test \\
\hline \multicolumn{6}{|c|}{ Grade 2} \\
\hline \multirow[t]{2}{*}{ Boys } & $\mathrm{M}$ & $17.29(7)$ & $19.14(7)$ & $19.30(10)$ & $20.40(10)$ \\
\hline & SD & 3.55 & 2.54 & 3.86 & 2.55 \\
\hline \multirow[t]{2}{*}{ Girls } & $\mathrm{M}$ & $19.17(12)$ & $19.50(12)$ & $20.33(9)$ & $19.22(9)$ \\
\hline & $\mathrm{SD}$ & 1.99 & 3.63 & 1.58 & 3.46 \\
\hline \multicolumn{6}{|c|}{ Grade 5} \\
\hline \multirow[t]{2}{*}{ Boys } & $\mathrm{M}$ & $20.67(9)$ & $18.11(9)$ & $17.40(10)$ & $17.90(10)$ \\
\hline & $\mathrm{SD}$ & 2.40 & 4.31 & 2.32 & 2.85 \\
\hline \multirow[t]{2}{*}{ Girls } & $\mathrm{M}$ & $17.45(11)$ & $16.09(11)$ & $18.18(11)$ & $18.18(11)$ \\
\hline & $\mathrm{SD}$ & 3.45 & 3.27 & 3.82 & 3.34 \\
\hline
\end{tabular}


Table 27

Means and Standard Deviations and $(\mathbf{N})$ for Children's Perception of "Women" in Stereotypic Gender Neutral Careers at Pre-test and Post-test by Grade, Gender, \& Treatment Group

\begin{tabular}{cccccc}
\hline & & \multicolumn{2}{c}{ Intervention } & \multicolumn{2}{c}{ Control } \\
\hline Grade 2 & & Pre-test & Post-test & Pre-test & Post-test \\
Boys & M & $15.14(7)$ & $16.86(7)$ & $16.30(10)$ & $16.90(10)$ \\
& SD & 2.54 & 3.29 & 4.67 & 3.90 \\
Girls & M & $17.67(12)$ & $17.33(12)$ & $16.89(9)$ & $16.11(9)$ \\
& SD & 6.63 & 4.12 & 3.48 & 4.17 \\
& & & & & \\
Grade 5 & & & & $15.60(10)$ & $15.80(10)$ \\
Boys & M & $18.22(9)$ & $16.56(9)$ & 2.41 & 1.87 \\
& SD & 3.42 & 4.03 & $16.09(11)$ & $17.00(11)$ \\
Girls & M & $16.09(11)$ & $15.91(11)$ & 2.27 & 4.05 \\
& SD & 3.48 & 3.48 & & \\
\hline
\end{tabular}


Table 28

Means and Standard Deviations and (N) for CSRI-Masculine by Grade, Gender, \& Treatment Group

\begin{tabular}{|c|c|c|c|c|c|}
\hline & & \multicolumn{2}{|c|}{ Intervention } & \multicolumn{2}{|c|}{ Control } \\
\hline & & Pre-test & Post-test & Pre-test & Post-test \\
\hline \multicolumn{6}{|c|}{ Grade 2} \\
\hline \multirow[t]{2}{*}{ Boys } & $\mathrm{M}$ & $2.29(7)$ & $2.71(7)$ & $2.50(10)$ & $2.38(10)$ \\
\hline & SD & .70 & .51 & .71 & .74 \\
\hline \multirow[t]{2}{*}{ Girls } & $\mathrm{M}$ & $2.27(12)$ & $2.06(12)$ & $2.70(10)$ & $2.03(9)$ \\
\hline & $\mathrm{SD}$ & .40 & .70 & .66 & .94 \\
\hline \multicolumn{6}{|c|}{ Grade 5} \\
\hline \multirow[t]{2}{*}{ Boys } & $\mathrm{M}$ & $2.33(8)$ & $2.47(8)$ & $2.70(10)$ & $2.50(10)$ \\
\hline & SD & .40 & .45 & .66 & .49 \\
\hline \multirow[t]{2}{*}{ Girls } & M & $2.07(11)$ & $2.05(11)$ & $2.52(11)$ & $2.50(11)$ \\
\hline & $\mathrm{SD}$ & .63 & .62 & .55 & .62 \\
\hline
\end{tabular}


Table 29

Means and Standard Deviations and (N) for CSRI-Feminine by Grade, Gender, \& Treatment Group

\begin{tabular}{cccccc}
\hline & \multicolumn{2}{c}{ Intervention } & \multicolumn{2}{c}{ Control } \\
& & Pre-test & Post-test & Pre-test & Post-test \\
\cline { 2 - 6 } Grade 2 & & & & \\
Boys & $\mathrm{M}$ & $2.89(7)$ & $3.29(7)$ & $3.05(10)$ & $3.05(10)$ \\
& $\mathrm{SD}$ & .63 & .76 & .74 & .70 \\
Girls & $\mathrm{M}$ & $3.48(12)$ & $3.21(12)$ & $2.83(9)$ & $3.56(9)$ \\
& $\mathrm{SD}$ & .56 & .59 & .60 & .58 \\
& & & & & \\
Grade 5 & & & & & \\
Boys & $\mathrm{M}$ & $2.89(9)$ & $3.16(8)$ & .64 & $.79(11)$ \\
& $\mathrm{SD}$ & .74 & .68 & & $2.75(10)$ \\
Girls & $\mathrm{M}$ & $3.50(11)$ & $3.16(10)$ & $3.48(11)$ & $3.52(11)$ \\
& $\mathrm{SD}$ & .37 & .63 & .41 & .41 \\
& & & & & \\
\hline
\end{tabular}


Table 30

Means and Standard Deviations and (N) for Perceived Competence - Scholastic by Grade, Gender, \& Treatment Group

\begin{tabular}{cccccc}
\hline & \multicolumn{2}{c}{ Intervention } & \multicolumn{2}{c}{ Control } \\
& & Pre-test & Post-test & Pre-test & Post-test \\
\cline { 2 - 6 } Grade 2 & & & & & \\
Boys & $\mathrm{M}$ & $3.27(7)$ & $3.06(7)$ & $2.79(10)$ & $2.97(10)$ \\
& $\mathrm{SD}$ & .48 & .96 & .50 & .58 \\
Girls & $\mathrm{M}$ & $2.85(12)$ & $2.67(12)$ & $2.20(90$ & $2.40(9)$ \\
& $\mathrm{SD}$ & .65 & 1.03 & .79 & .87 \\
& & & & & \\
Grade 5 & & & & & \\
Boys. & $\mathrm{M}$ & $3.26(9)$ & $3.00(9)$ & $2.90(10)$ & $2.98(10)$ \\
& $\mathrm{SD}$ & .65 & .32 & .69 & .76 \\
Girls & $\mathrm{M}$ & $2.76(11)$ & $2.95(11)$ & $3.09(11)$ & $3.17(11)$ \\
& $\mathrm{SD}$ & .60 & .67 & .79 & .79 \\
& & & & & \\
\hline
\end{tabular}


Table 31

Means and Standard Deviations and $(\mathrm{N})$ for Perceived Competence - Social by Grade, Gender, \& Treatment Group

\begin{tabular}{|c|c|c|c|c|c|}
\hline & & \multicolumn{2}{|c|}{ Intervention } & \multicolumn{2}{|c|}{ Control } \\
\hline & & Pre-test & Post-test & Pre-test & Post-test \\
\hline \multicolumn{6}{|c|}{ Grade 2} \\
\hline \multirow[t]{2}{*}{ Boys } & $\mathbf{M}$ & $3.00(7)$ & $3.06(7)$ & $2.83(9)$ & $2.97(10)$ \\
\hline & $\mathrm{SD}$ & .63 & .96 & .62 & .58 \\
\hline \multirow[t]{2}{*}{ Girls } & $\mathrm{M}$ & $2.65(13)$ & $2.67(12)$ & $2.38(9)$ & $2.40(9)$ \\
\hline & SD & .71 & 1.03 & .86 & .87 \\
\hline \multicolumn{6}{|c|}{ Grade 5} \\
\hline \multirow[t]{2}{*}{ Boys } & $\mathrm{M}$ & $2.94(9)$ & $3.00(9)$ & $2.89(10)$ & $2.98(10)$ \\
\hline & SD & .67 & .32 & .77 & .76 \\
\hline \multirow[t]{2}{*}{ Girls } & $\mathrm{M}$ & $2.92(11)$ & $2.95(11)$ & $2.67(11)$ & $3.17(11)$ \\
\hline & SD & .64 & .67 & .88 & .79 \\
\hline
\end{tabular}


Table 32

Means and Standard Deviations and (N) for Perceived Competence - Athletic by Grade, Gender, \& Treatment Group

\begin{tabular}{|c|c|c|c|c|c|}
\hline & & \multicolumn{2}{|c|}{ Intervention } & \multicolumn{2}{|c|}{ Control } \\
\hline & & Pre-test & Post-test & Pre-test & Post-test \\
\hline \multicolumn{6}{|c|}{ Grade 2} \\
\hline \multirow[t]{2}{*}{ Boys } & $\mathrm{M}$ & $3.1797)$ & $3.43(7)$ & $3.23(10)$ & $3.11(9)$ \\
\hline & SD & .82 & .67 & .83 & .64 \\
\hline \multirow[t]{2}{*}{ Girls } & $M$ & $2.63(12)$ & $3.14(12)$ & $1.86(9)$ & $2.49(9)$ \\
\hline & SD & .68 & .69 & .78 & 1.02 \\
\hline \multicolumn{6}{|c|}{ Grade 5} \\
\hline \multirow[t]{2}{*}{ Boys } & M & $3.07(9)$ & $3.11(9)$ & $2.80(10)$ & $3.10(9)$ \\
\hline & SD & .89 & .64 & .64 & .51 \\
\hline \multirow[t]{2}{*}{ Girls } & M & $2.50(11)$ & $2.49(10)$ & $2.92(11)$ & $2.97(11)$ \\
\hline & SD & .94 & 1.02 & .79 & .73 \\
\hline
\end{tabular}


Table 33

Means and Standard Deviations and (N) for Perceived Competence - Physical by Grade, Gender, \& Treatment Group

\begin{tabular}{|c|c|c|c|c|c|}
\hline & & \multicolumn{2}{|c|}{ Intervention } & \multicolumn{2}{|c|}{ Control } \\
\hline & & Pre-test & Post-test & Pre-test & Post-test \\
\hline \multicolumn{6}{|c|}{ Grade 2} \\
\hline \multirow[t]{2}{*}{ Boys } & $\mathrm{M}$ & $3.17(6)$ & $3.03(7)$ & $2.93(10)$ & $3.19(10)$ \\
\hline & $\mathrm{SD}$ & .49 & .93 & .70 & .58 \\
\hline \multirow[t]{2}{*}{ Girls } & $\mathrm{M}$ & $3.03(12)$ & $3.15(12)$ & $2.43(9)$ & $2.72(9)$ \\
\hline & $\mathrm{SD}$ & .59 & .70 & .99 & .91 \\
\hline \multicolumn{6}{|c|}{ Grade 5} \\
\hline \multirow[t]{2}{*}{ Boys } & $\mathrm{M}$ & $2.72(9)$ & $3.00(9)$ & $2.91(10)$ & $3.09(10)$ \\
\hline & SD & .87 & .95 & .73 & .58 \\
\hline \multirow[t]{2}{*}{ Girls } & $\mathrm{M}$ & $2.55(10)$ & $2.63(10)$ & $2.79(11)$ & $3.04(11)$ \\
\hline & $\mathrm{SD}$ & .97 & 1.05 & .59 & .94 \\
\hline
\end{tabular}


Table 34

Means and Standard Deviations and $(\mathrm{N})$ for Perceived Competence - Behavior by Grade, Gender, \& Treatment Group

\begin{tabular}{|c|c|c|c|c|c|}
\hline & & \multicolumn{2}{|c|}{ Intervention } & \multicolumn{2}{|c|}{ Control } \\
\hline & \multicolumn{3}{|c|}{ Pre-test } & Post-test & Pre-testPost-test \\
\hline \multicolumn{6}{|c|}{ Grade 2} \\
\hline \multirow[t]{2}{*}{ Boys } & $\mathrm{M}$ & $3.27(7)$ & $3.56(7)$ & $2.62(10)$ & $3.71(10)$ \\
\hline & $\mathrm{SD}$ & .67 & .55 & .80 & .65 \\
\hline \multirow[t]{2}{*}{ Girls } & M & $3.28(12)$ & $3.48(12)$ & $3.08(9)$ & $2.72(9)$ \\
\hline & $\mathrm{SD}$ & .55 & .53 & .52 & .99 \\
\hline \multicolumn{6}{|c|}{ Grade 5} \\
\hline \multirow[t]{2}{*}{ Boys } & $\mathrm{M}$ & $2.78(9)$ & $3.08(9)$ & $2.93(10)$ & 3.24 (10) \\
\hline & $\mathrm{SD}$ & .36 & .73 & .36 & .30 \\
\hline \multirow[t]{2}{*}{ Girls } & $\mathrm{M}$ & $3.16(10)$ & $2.87(10)$ & $3.65(11)$ & $3.46(11)$ \\
\hline & $\mathrm{SD}$ & .30 & .45 & .32 & .33 \\
\hline
\end{tabular}


Table 35

Means and Standard Deviations and (N) for Perceived Competence - Global by Grade, Gender, \& Treatment Group

\begin{tabular}{|c|c|c|c|c|c|}
\hline & & \multicolumn{2}{|c|}{ Intervention } & \multicolumn{2}{|c|}{ Control } \\
\hline & \multicolumn{3}{|c|}{ Pre-test } & Post-test & Pre-testPost-test \\
\hline \multicolumn{6}{|c|}{ Grade 2} \\
\hline \multirow[t]{2}{*}{ Boys } & $\mathrm{M}$ & $3.17(7)$ & $3.17(7)$ & $3.19(9)$ & $3.26(10)$ \\
\hline & $\mathrm{SD}$ & .82 & .57 & .56 & .55 \\
\hline \multirow[t]{2}{*}{ Girls } & $\mathrm{M}$ & $3.35(12)$ & $3.30(12)$ & $2.29(9)$ & $2.89(9)$ \\
\hline & $\mathrm{SD}$ & .57 & .82 & 1.00 & 1.08 \\
\hline \multicolumn{6}{|c|}{ Grade 5} \\
\hline \multirow[t]{2}{*}{ Boys } & $\mathbf{M}$ & $3.29(9)$ & $3.33(9)$ & $3.24(10)$ & $3.39(10)$ \\
\hline & $\mathrm{SD}$ & .68 & .59 & .45 & .49 \\
\hline \multirow[t]{2}{*}{ Girls } & $\mathbf{M}$ & $2.98(10)$ & $2.85(10)$ & $3.15(11)$ & $3.29(11)$ \\
\hline & $\mathrm{SD}$ & .89 & .88 & .77 & .69 \\
\hline
\end{tabular}


Table 36

Summary Table of $(2 \times 2 \times 2)$ ANOVA (Gender $\times$ Grade $\times$ Intervention) for Occupational Choice Survey (OCS)

\begin{tabular}{lcccc}
\hline Source & SS & DF & MS & F \\
\hline Covariate & 146.19 & 1,77 & 146.19 & $132.00^{* * *}$ \\
Main Effects & 15.15 & 3,77 & 5.05 & $4.56^{* * *}$ \\
Gender & 13.14 & 1,77 & 13.14 & $11.87^{* * *}$ \\
Grade & .50 & 1,77 & .50 & .45 \\
I.C. & .67 & 1,77 & .67 & .61 \\
2-Way Interactions & .37 & 3,77 & .12 & .11 \\
Gender/Grade & .06 & 1,77 & .06 & $.05^{* *}$ \\
Gender/I.C. & .30 & 1,77 & .30 & .27 \\
Grade/I.C. & .01 & 1,77 & .01 & $.01 * * *$ \\
3-Way Interactions & .70 & 1,77 & .70 & .63 \\
\hline
\end{tabular}

${ }^{\text {a }}$ I.C. $=$ Intervention Condition

$* \mathrm{p} \leq .10 * * \mathrm{p} \leq .05 * * * \mathrm{p} \leq .01$ 
Table 37

Summary of $(2 \times 2 \times 2)$ Analysis of Covariance (Gender x Grade $\times$ Intervention) for Pre-test Covariate Scores

\begin{tabular}{lllll}
\hline Source & SS & DF & MS & F \\
\hline You - Masculine & 653.30 & 1,78 & 653.30 & $112.36^{* * *}$ \\
You - Feminine & 940.06 & 1,78 & 940.06 & $171.97^{* * *}$ \\
You - Neutral & 716.68 & 1,78 & 716.68 & $120.45^{* * *}$ \\
Man - Masculine & 183.72 & 1,78 & 183.72 & $18.39^{* * *}$ \\
Man - Feminine & 347.29 & 1,78 & 347.29 & $54.27^{* * *}$ \\
Man - Neutral & 404.65 & 1,78 & 404.65 & $54.25^{* * *}$ \\
Woman - Masculine & 496.90 & 1,78 & 496.90 & $66.31^{* * *}$ \\
Woman - Feminine & 151.58 & 1,78 & 151.58 & $16.22^{* * *}$ \\
Woman - Neutral & 425.95 & 1,78 & 425.95 & $56.13^{* * *}$ \\
\hline
\end{tabular}

$* \mathrm{p} \leq .10 * * \mathrm{p} \leq .05 * * * \mathrm{p} \leq .01$ 
Table 38

Means and Standard Deviations for Total Sample for Stereotypic Occupational Scale(SOS) at Pre-test and Post-test

\begin{tabular}{lccll}
\hline & \multicolumn{3}{c}{ Pre-test } & \multicolumn{2}{c}{ Post-test } \\
\hline & M & SD & M & SD \\
\cline { 2 - 5 } You - Masculine & 11.42 & 4.21 & 12.03 & 3.75 \\
You - Feminine & 10.25 & 4.12 & 11.00 & 4.27 \\
You - Neutral & 11.62 & 4.11 & 12.30 & 4.02 \\
Man - Masculine & 20.42 & 3.23 & 20.00 & 3.49 \\
Man - Feminine & 12.53 & 3.13 & 12.87 & 3.31 \\
Man - Neutral & 16.86 & 3.44 & 16.48 & 3.62 \\
Woman - Masculine & 12.15 & 3.56 & 13.17 & 3.71 \\
Woman - Feminine & 18.72 & 3.10 & 18.53 & 3.40 \\
Woman - Neutral & 16.54 & 3.23 & 16.57 & 3.58 \\
\hline
\end{tabular}


Table 39

Summary of Main Effects for Dutton Measures-ANCOVA at Post-test with Pre-test as Covariate

\begin{tabular}{llll}
\hline Dependent Measures & $\begin{array}{l}\text { Main Effect } \\
\text { I.C. }\end{array}$ & $\begin{array}{l}\text { Main Effect } \\
\text { Gender }\end{array}$ & $\begin{array}{l}\text { Main Effect } \\
\text { Grade }\end{array}$ \\
\hline & $\mathrm{p}$ & $\mathrm{p}$ & $\mathrm{p}$ \\
\cline { 2 - 4 } You - Masculine & .32 & .91 & .53 \\
You - Feminine & .24 & .16 & .24 \\
You - Neutral & $.08^{*}$ & $.03^{* *}$ & $.07^{*}$ \\
Man - Masculine & .73 & .54 & .16 \\
Man - Feminine & $.06^{*}$ & .88 & .69 \\
Man - Neutral & .17 & .58 & .95 \\
Woman - Masculine & $.08^{*}$ & .48 & .42 \\
Woman - Feminine & .32 & .37 & $.01 * * *$ \\
Woman - Neutral & .64 & .88 & .55 \\
* $\leq .10 * *$ p $\leq .05 * * *$ & $\mathrm{p} \leq .01$ & &
\end{tabular}


Table 40

Summary of Interactions for Dutton Measures- $(2 \times 2 \times 2)$ Analysis of Covariance (Gender x Grade $x$ Intervention) at Post-test with Pre-test as Covariate

\begin{tabular}{|c|c|c|c|c|}
\hline Dependent Measures & $\begin{array}{l}2 \text { - Way } \\
\text { GDR }^{\mathrm{a}} \text { x GRADE }\end{array}$ & $\begin{array}{l}2 \text { - Way } \\
\text { GDR x I.C. }\end{array}$ & $\begin{array}{l}2 \text { - Way } \\
\text { GRADE x } \\
\text { I.C. }\end{array}$ & 3 - Way \\
\hline & $\mathrm{p}$ & $\mathrm{p}$ & $\mathrm{p}$ & $\mathrm{p}$ \\
\hline You - Masculine & .36 & .45 & .41 & .39 \\
\hline You - Feminine & .95 & .23 & .24 & $.01 * * *$ \\
\hline You - Neutral & .42 & .56 & $.04 * *$ & .31 \\
\hline Man - Masculine & .50 & .59 & $.06^{*}$ & .74 \\
\hline Man - Feminine & .67 & .59 & $.03 * *$ & .81 \\
\hline Man - Neutral & .92 & .59 & $.01 * * *$ & .40 \\
\hline Woman - Masculine & .76 & .91 & .11 & .84 \\
\hline Woman - Feminine & .58 & .84 & .20 & .55 \\
\hline Woman - Neutral & $.09 *$ & .98 & .13 & .91 \\
\hline
\end{tabular}

${ }^{a}$ GDR $=$ Gender.

$* \mathrm{p} \leq .10 * * \mathrm{p} \leq .05 * * * \mathrm{p} \leq .01$ 
Table 41

Summary Table of $(2 \times 2 \times 2)$ Analysis of Covariance (Gender $\times$ Grade $\times$ Intervention) for Three Subscales of the Dutton - "You" Scale

\begin{tabular}{|c|c|c|c|c|}
\hline Source & SS & $\mathrm{DF}$ & MS & $\mathrm{F}$ \\
\hline \multicolumn{5}{|l|}{ MASCULINE } \\
\hline Covariate & 653.30 & 1,77 & 653.30 & $112.36 * * *$ \\
\hline Main Effects & 08.12 & 3,77 & 2.71 & .47 \\
\hline Gender & 00.07 & 1,77 & 00.07 & .01 \\
\hline Grade & 2.30 & 1,77 & 2.30 & .40 \\
\hline I.C. & 5.79 & 1,77 & 5.79 & 1.00 \\
\hline 2-Way Interactions & 12.91 & 3,77 & 4.30 & .74 \\
\hline Gender/Grade & 4.85 & 1,77 & 4.85 & .83 \\
\hline Gender/I.C. & 3.32 & 1,77 & 3.32 & .57 \\
\hline Grade/I.C. & 3.93 & 1,77 & 3.93 & .68 \\
\hline 3-Way Interactions & 4.44 & 1,77 & 4.44 & .76 \\
\hline \multicolumn{5}{|l|}{ FEMININE } \\
\hline Covariate & 940.06 & 1,77 & 940.06 & $171.91 * * *$ \\
\hline Main Effects & 26.05 & 3,77 & 8.68 & 1.59 \\
\hline Gender & 10.82 & 1,77 & 10.82 & 1.98 \\
\hline Grade & 7.75 & 1,77 & 7.75 & 1.42 \\
\hline I.C. ${ }^{\mathrm{a}}$ & 7.82 & 1,77 & 7.82 & 1.43 \\
\hline 2-Way Interactions & 16.33 & 3,77 & 5.44 & 1.00 \\
\hline Gender/Grade & .02 & 1,77 & .02 & .01 \\
\hline Gender/I.C. & 8.08 & 1,77 & 8.08 & 1.48 \\
\hline Grade/I.C. & 7.55 & 1,77 & 7.55 & 1.38 \\
\hline 3-Way Interactions & 46.39 & 1,77 & 46.39 & $8.49 * * *$ \\
\hline \multicolumn{5}{|l|}{ NEUTRAL } \\
\hline Covariate & 716.68 & 1,77 & 716.68 & $120.45 * * *$ \\
\hline Main Effects & 77.72 & 3,77 & 25.91 & 4.35 \\
\hline Gender & 29.02 & 1,77 & 29.02 & $4.88 * *$ \\
\hline Grade & 19.95 & 1,77 & 19.95 & $3.35 *$ \\
\hline I.C. & 18.30 & 1,77 & 18.30 & $3.08 *$ \\
\hline 2-Way Interactions & 33.05 & 3,77 & 11.02 & 1.85 \\
\hline Gender/Grade & 3.85 & 1,77 & 3.85 & .65 \\
\hline Gender/I.C. & 2.09 & 1,77 & 2.09 & .35 \\
\hline Grade/I.C. & 26.63 & 1,77 & 26.63 & $4.48 * *$ \\
\hline 3-Way Interactions & 6.23 & 1,77 & 6.23 & 1.05 \\
\hline
\end{tabular}


Table 42

Summary Table of $(2 \times 2 \times 2)$ Analysis of Covariance (Gender $\times$ Grade $\times$ Intervention) for Three Subscales of the Dutton- "Man" Scale

\begin{tabular}{lcccc}
\hline Source & SS & DF & MS & F \\
\hline MASCULINE & & & & \\
Covariate & 183.72 & 1,77 & 183.72 & $18.39^{* * *}$ \\
Main Effects & 24.98 & 3,77 & 8.33 & .83 \\
Gender & 03.83 & 1,77 & 03.83 & .38 \\
Grade & 19.83 & 1,77 & 19.83 & 1.99 \\
I.C. ${ }^{\text {a }}$ & 1.24 & 1,77 & 1.24 & .12 \\
2-Way Interactions & 42.92 & 3,77 & 14.31 & 1.43 \\
Gender/Grade & 4.68 & 1,77 & 4.68 & .47 \\
Gender/I.C. & 2.95 & 1,77 & 2.95 & .30 \\
Grade/I.C. & 37.83 & 1,77 & 37.83 & $3.79 *$ \\
3-Way Interactions & 1.09 & 1,77 & 1.09 & .11 \\
& & & & \\
FEMININE & & & & \\
Covariate & 347.29 & 1,77 & 347.29 & $54.27 * * *$ \\
Main Effects & 25.18 & 3,77 & 8.39 & 1.31 \\
Gender & 00.14 & 1,77 & 00.14 & .02 \\
Grade & 1.03 & 1,77 & 1.03 & .16 \\
I.C. & 24.11 & 1,77 & 24.11 & $3.77 *$ \\
2-Way Interactions & 33.93 & 3,77 & 11.31 & 1.77 \\
Gender/Grade & 1.20 & 1,77 & 1.20 & .19 \\
Gender/I.C. & 1.89 & 1,77 & 01.89 & .30 \\
Grade/I.C. & 32.03 & 1,77 & 32.03 & 5.01 \\
3-Way Interactions & 00.39 & 1,77 & 00.39 & $.06^{* *}$
\end{tabular}

\section{NEUTRAL}

$\begin{array}{lcccc}\text { Covariate } & 404.65 & 1,77 & 404.65 & 54.25^{* * *} \\ \text { Main Effects } & 15.72 & 3,77 & 5.24 & 0.70 \\ \text { Gender } & 02.27 & 1,77 & 2.27 & 0.31 \\ \text { Grade } & 00.04 & 1,77 & .04 & 0.01 \\ \text { I.C. }^{\mathrm{a}} & 14.39 & 1,77 & 14.39 & 1.93 \\ \text { 2-Way Interactions } & 75.86 & 3,77 & 25.29 & 3.39 * * \\ \text { Gender/Grade } & 0.07 & 1,77 & .07 & .01 \\ \text { Gender/I.C. } & 2.15 & 1,77 & 2.15 & .29 \\ \text { Grade/I.C. } & 74.12 & 1,77 & 74.12 & 9.94 * * * \\ \text { 3-Way Interactions } & 5.35 & 1,77 & 5.35 & 0.72\end{array}$

$* \mathrm{p} \leq .10 * * \mathrm{p} \leq .05 * * * \mathrm{p} \leq .01$ 
Table 43

Summary Table of $(2 \times 2 \times 2)$ Analysis of Covariance (Gender $\times$ Grade $\times$ Intervention) for Three Subscales of the Dutton- "Woman" Scale

\section{Source \\ MASCULINE}

Covariate

Main Effects

Gender

Grade

I.C. ${ }^{\mathrm{a}}$

2-Way Interactions

Gender/Grade

Gender/I.C.

Grade/I.C.

3-Way Interactions

\section{FEMININE}

Covariate

Main Effects

Gender

Grade

I.C. ${ }^{a}$

2-Way Interactions

Gender/Grade

Gender/I.C.

Grade/I.C.

3-Way Interactions

\section{NEUTRAL}

Covariate

Main Effects

Gender

Grade

I.C. ${ }^{a}$

2-Way Interactions

Gender/Grade

Gender/I.C.

Grade/I.C.

3-Way Interactions

SS DF

DF

MS

F

$\begin{array}{cccc}496.96 & 1,77 & 496.90 & 66.31^{* * *} \\ 31.24 & 3,77 & 10.41 & 1.39 \\ 03.84 & 1,77 & 3.83 & .51 \\ 5.05 & 1,77 & 5.05 & .67 \\ 23.28 & 1,77 & 23.28 & 3.11^{*} \\ 19.80 & 3,77 & 6.60 & .88 \\ .68 & 1,77 & .68 & .09 \\ .10 & 1,77 & .10 & .01 \\ 19.37 & 1,77 & 19.37 & 2.59 \\ .33 & 1,77 & .33 & .04\end{array}$

$\begin{array}{cccc}151.58 & 1,77 & 151.58 & 16.22^{* * *} \\ 77.27 & 3,77 & 25.76 & 2.76^{* *} \\ 7.52 & 1,77 & 7.52 & .80 \\ 60.14 & 1,77 & 60.14 & 6.43^{* *} \\ 9.27 & 1,77 & 9.27 & .99 \\ 17.21 & 3,77 & 5.74 & .61 \\ 2.87 & 1,77 & 2.87 & .31 \\ .41 & 1,77 & .41 & .04 \\ 15.57 & 1,77 & 15.57 & 1.67 \\ 3.31 & 1,77 & 3.31 & .35\end{array}$

$\begin{array}{cccc}425.95 & 1,77 & 425.95 & 56.13^{* * *} \\ 4.69 & 3,77 & 1.56 & 0.21 \\ .15 & 1,77 & .15 & 0.02 \\ 2.78 & 1,77 & 2.78 & 0.37 \\ 1.71 & 1,77 & 1.71 & .23 \\ 35.41 & 3,77 & 11.80 & 1.56 \\ 22.60 & 1,77 & 22.60 & 2.98^{*} \\ .01 & 1,77 & .01 & .01 \\ 16.68 & 1,77 & 16.68 & 2.20 \\ .10 & 1,77 & .10 & 0.01\end{array}$

$* \mathrm{p} \leq .10 * * \mathrm{p} \leq .05 * * * \mathrm{p} \leq .01$ 
Table 44

Summary Table of $(2 \times 2 \times 2)$ Analysis of Covariance (Gender $\times$ Grade $\times$ Intervention) for Two Subscales of the CSRI Scale

\begin{tabular}{|c|c|c|c|c|}
\hline Source & SS & $\overline{\mathrm{DF}}$ & MS & $F$ \\
\hline \multicolumn{5}{|l|}{ MASCULINE } \\
\hline Covariate & 9.58 & 1,77 & 9.58 & $29.39 * * *$ \\
\hline Main Effects & .92 & 3,77 & .31 & .94 \\
\hline Gender & .89 & 1,77 & .89 & 2.72 \\
\hline Grade & .04 & 1,77 & .04 & .12 \\
\hline I.C. ${ }^{\mathrm{a}}$ & .02 & 1,77 & .02 & .05 \\
\hline 2-Way Interactions & 1.52 & 3,77 & .51 & 1.55 \\
\hline Gender/Grade & .27 & 1,77 & .27 & .84 \\
\hline Gender/I.C. & 1.10 & 1,77 & 1.10 & $3.39 *$ \\
\hline Grade/I.C. & .15 & 1,77 & .15 & .46 \\
\hline 3-Way Interactions & .03 & 1,77 & .03 & .10 \\
\hline \multicolumn{5}{|l|}{ FEMININE } \\
\hline Covariate & 13.19 & 1,77 & 13.19 & $51.79 * * *$ \\
\hline Main Effects & .27 & 3,77 & .09 & .36 \\
\hline Gender & .04 & 1,77 & .04 & .14 \\
\hline Grade & .15 & 1,77 & .15 & .59 \\
\hline I.C. ${ }^{a}$ & .08 & 1,77 & .08 & .33 \\
\hline 2-Way Interactions & 2.39 & 3,77 & .80 & 3.12 \\
\hline Gender/Grade & .05 & 1,77 & .05 & .20 \\
\hline Gender/I.C. & 2.33 & 1,77 & 2.33 & $9.13 * * *$ \\
\hline Grade/I.C. & .01 & 1,77 & .01 & .01 \\
\hline 3-Way Interactions & .01 & 1,77 & .01 & .01 \\
\hline
\end{tabular}


Table 45

Summary of Pre-test Covariate Score for $2 \times 2 \times 2$ (Gender x Grade x Treatment Group) Analysis of Variance for the Perceived Competence Scale

\begin{tabular}{lllll}
\hline Source & SS & DF & MS & F \\
\hline Scholastic & 21.94 & 1,78 & 21.94 & $131.77^{* * *}$ \\
Social & 25.42 & 1,78 & 25.42 & $099.13^{* * *}$ \\
Athletic & 43.20 & 1,78 & 43.20 & $252.96^{* * *}$ \\
Physical & 33.24 & 1,78 & 33.24 & $126.20^{* * *}$ \\
Behavioral & 15.28 & 1,78 & 15.28 & $079.62^{* * *}$ \\
Global & 21.87 & 1,78 & 21.87 & $090.05^{* * *}$ \\
\hline
\end{tabular}

$* \mathrm{p} \leq .10 * * \mathrm{p} \leq .05 * * * \mathrm{p} \leq .01$ 
Table 46

Summary Table of $(2 \times 2 \times 2)$ Analysis of Covariance (Gender $\times$ Grade $\times$ Intervention) for Three Subscales of the Self Perception Scale for Children

\begin{tabular}{|c|c|c|c|c|}
\hline Source & SS & $\mathrm{DF}$ & MS & $\mathrm{F}$ \\
\hline \multicolumn{5}{|l|}{$\overline{\text { SCHOLASTIC }}$} \\
\hline Covariate & 21.94 & 1,77 & 21.94 & $131.77^{* * * *}$ \\
\hline Main Effects & .71 & 3,77 & .24 & 1.42 \\
\hline Gender & .06 & 1,77 & .06 & .37 \\
\hline Grade & .35 & 1,77 & .35 & 2.08 \\
\hline I.C. ${ }^{\mathrm{a}}$ & .25 & 1,77 & .25 & 1.50 \\
\hline 2-Way Interactions & .81 & 3,77 & .27 & 1.61 \\
\hline Gender/Grade & .06 & 1,77 & .06 & .36 \\
\hline Gender/I.C. & .50 & 1,77 & .50 & $3.01 *$ \\
\hline Grade/I.C. & .24 & 1,77 & .24 & 1.41 \\
\hline 3-Way Interactions & .04 & 1,77 & .04 & .23 \\
\hline \multicolumn{5}{|l|}{ SOCIAL } \\
\hline Covariate & 25.42 & 1,77 & 25.42 & $99.13 * * *$ \\
\hline Main Effects & .60 & 3,77 & .20 & .78 \\
\hline Gender & .01 & 1,77 & .01 & .01 \\
\hline Grade & .23 & 1,77 & .23 & .90 \\
\hline I.C. ${ }^{\mathrm{a}}$ & .36 & 1,77 & .36 & 1.41 \\
\hline 2-Way Interactions & .97 & 3,77 & .32 & 1.26 \\
\hline Gender/Grade & .77 & 1,77 & .77 & $3.02 *$ \\
\hline Gender/I.C. & .08 & 1,77 & .08 & .31 \\
\hline Grade/I.C. & .16 & 1,77 & .16 & .62 \\
\hline 3-Way Interactions & .51 & 1,77 & .51 & 2.00 \\
\hline \multicolumn{5}{|l|}{ ATHLETIC } \\
\hline Covariate & 43.20 & 1,77 & 43.20 & $252.96 * * *$ \\
\hline Main Effects & .19 & 3,77 & 0.06 & .37 \\
\hline Gender & .06 & 1,77 & .06 & .34 \\
\hline Grade & .01 & 1,77 & 0.01 & .02 \\
\hline I.C. ${ }^{\mathrm{a}}$ & .14 & 1,77 & 0.14 & .81 \\
\hline 2-Way Interactions & .57 & 3,77 & .19 & 1.12 \\
\hline Gender/Grade & .01 & 1,77 & .01 & .03 \\
\hline Gender/I.C. & .01 & 1,77 & .01 & .05 \\
\hline Grade/I.C. & .54 & 1,77 & .54 & $3.19 *$ \\
\hline 3-Way Interactions & .05 & 1,77 & .05 & .26 \\
\hline
\end{tabular}


Table 47

Summary Table of $(2 \times 2 \times 2)$ Analysis of Covariance (Gender $\times$ Grade $\times$ Intervention) for Three Subscales of the Harter Self Perception Scale

\begin{tabular}{|c|c|c|c|c|}
\hline Source & SS & DF & MS & $\mathrm{F}$ \\
\hline \multicolumn{5}{|l|}{ PHYSICAL } \\
\hline Covariate & 33.24 & 1,77 & 33.24 & $126.20 * * *$ \\
\hline Main Effects & .11 & 3,77 & .04 & .14 \\
\hline Gender & .01 & 1,77 & .01 & .05 \\
\hline Grade & .01 & 1,77 & .01 & .01 \\
\hline I.C. & .09 & 1,77 & .09 & .35 \\
\hline 2-Way Interactions & .36 & 3,77 & .12 & .45 \\
\hline Gender/Grade & .25 & 1,77 & .25 & .96 \\
\hline Gender/I.C. & .09 & 1,77 & .09 & .36 \\
\hline Grade/I.C. & .01 & 1,77 & .01 & .05 \\
\hline 3-Way Interactions & .08 & 1,77 & .08 & .32 \\
\hline \multicolumn{5}{|l|}{ BEHAVIORAL } \\
\hline Covariate & 15.28 & 1,77 & 15.28 & $79.63 * * *$ \\
\hline Main Effects & 2.59 & 3,77 & .86 & $4.51 * * *$ \\
\hline Gender & .13 & 1,77 & .13 & .66 \\
\hline Grade & .01 & 1,77 & .01 & .01 \\
\hline I.C. ${ }^{\mathrm{a}}$ & 2.53 & 1,77 & 2.53 & $13.17 * * *$ \\
\hline 2-Way Interactions & .51 & 3,77 & .17 & .88 \\
\hline Gender/Grade & .14 & 1,77 & .14 & .72 \\
\hline Gender/I.C. & .01 & 1,77 & .01 & .01 \\
\hline Grade/I.C. & .41 & 1,77 & .41 & 2.14 \\
\hline 3-Way Interactions & .11 & 1,77 & .11 & .56 \\
\hline \multicolumn{5}{|l|}{ GLOBAL } \\
\hline Covariate & 21.87 & 1,77 & 21.87 & $90.05 * * *$ \\
\hline Main Effects & .79 & 3,77 & .26 & 1.09 \\
\hline Gender & .01 & 1,77 & .01 & .01 \\
\hline Grade & .05 & 1,77 & .05 & .21 \\
\hline I.C. ${ }^{\mathrm{a}}$ & .76 & 1,77 & .76 & $3.14 *$ \\
\hline 2-Way Interactions & .39 & 3,77 & .13 & .54 \\
\hline Gender/Grade & .21 & 1,77 & .21 & .86 \\
\hline Gender/I.C. & .15 & 1,77 & .15 & .64 \\
\hline Grade/I.C. & .05 & 1,77 & .05 & .21 \\
\hline 3-Way Interactions & .02 & 1,77 & .02 & .08 \\
\hline
\end{tabular}


Table 48

Summary of Paired t-test Results for Occupational Choice Survey (OCS)

\begin{tabular}{llll}
\hline & T Value & DF & $\mathrm{p}$ \\
\hline Grade 2 & 1.55 & 1,37 & 0.130 \\
Grade 5 & 3.19 & 1,39 & $0.001^{*}$ \\
Boys & 1.53 & 1,35 & 0.136 \\
Girls & 2.68 & 1,41 & $0.011^{*}$ \\
Intervention & 3.30 & 1,37 & $0.002^{*}$ \\
Control & 1.20 & 1,39 & 0.238 \\
Intervention Grade 2 & 1.82 & 1,18 & 0.086 \\
Intervention Grade 5 & 3.28 & 1,18 & $0.004^{*}$ \\
Control Grade 2 & 0.47 & 1,18 & 0.644 \\
Control Grade 5 & 1.45 & 1,20 & 0.162 \\
Girls Intervention & 2.49 & 1,21 & $0.021^{*}$ \\
Girls Control & 1.34 & 1,19 & 0.197 \\
Boys Grade 2 & 0.37 & 1,16 & 0.718 \\
Boys Grade 5 & 1.76 & 1,18 & 0.096 \\
Girls Grade 2 & 1.52 & 1,20 & 0.143 \\
Girls Grade 5 & 2.68 & 1,20 & $0.015^{*}$ \\
Boys Intervention & 3.00 & 1,15 & $0.009^{*}$ \\
Boys Control & 0.01 & 1,19 & 1.000 \\
\hline
\end{tabular}

$* \mathrm{p} \leq .06$ 
Table 49

Summary of Paired t-test Results for Stereotypic Occupational Scale (SOS) for You Masculine

\begin{tabular}{llll}
\hline & $\mathrm{T}$ Value & $\mathrm{DF}$ & $\mathrm{p}$ \\
\hline Grade 2 & 0.28 & 1,37 & 0.706 \\
Grade 5 & 2.49 & 1,39 & $0.017^{*}$ \\
Boys & 0.15 & 1,35 & 0.880 \\
Girls & 3.28 & 1,41 & $0.002^{*}$ \\
Intervention & 2.31 & 1,37 & $0.027^{*}$ \\
Control & 0.66 & 1,39 & 0.511 \\
Intervention Grade 2 & 1.93 & 1,18 & 0.070 \\
Intervention Grade 5 & 1.29 & 1,18 & 0.215 \\
Control Grade 2 & 0.80 & 1,18 & 0.433 \\
Control Grade 5 & 2.15 & 1,20 & $0.044^{*}$ \\
Girls Intervention & 3.13 & 1,21 & $0.005^{*}$ \\
Girls Control & 1.49 & 1,19 & 0.153 \\
Boys Grade 2 & 1.16 & 1,16 & 0.263 \\
Boys Grade 5 & 1.61 & 1,18 & 0.126 \\
Girls Grade 2 & 2.55 & 1,20 & $0.019^{*}$ \\
Girls Grade 5 & 2.02 & 1,20 & $0.057^{*}$ \\
Boys Intervention & 0.31 & 1,15 & 0.762 \\
Boys Control & 0.01 & 1,19 & 1.000 \\
\hline
\end{tabular}

* $\mathrm{p} \leq .06$ 
Table 50

Summary of Paired t-test Results for Stereotypic Occupational Scale (SOS) for You Feminine

\begin{tabular}{llll}
\hline & T Value & DF & $\mathrm{p}$ \\
\hline Grade 2 & 1.33 & 1,37 & 0.191 \\
Grade 5 & 3.08 & 1,39 & $0.004^{*}$ \\
Boys & 1.83 & 1,35 & 0.076 \\
Girls & 1.82 & 1,41 & 0.076 \\
Intervention & 3.27 & 1,37 & $0.002^{*}$ \\
Control & 0.83 & 1,39 & 0.412 \\
Intervention Grade 2 & 2.87 & 1,18 & $0.010^{*}$ \\
Intervention Grade 5 & 1.68 & 1,18 & 0.110 \\
Control Grade 2 & 0.12 & 1,18 & 0.908 \\
Control Grade 5 & 2.88 & 1,20 & $0.009 *$ \\
Girls Intervention & 2.73 & 1,21 & $0.012^{*}$ \\
Girls Control & 0.15 & 1,19 & 0.883 \\
Boys Grade 2 & 1.06 & 1,16 & 0.304 \\
Boys Grade 5 & 1.69 & 1,18 & 0.108 \\
Girls Grade 2 & 0.85 & 1,20 & 0.406 \\
Girls Grade 5 & 2.69 & 1,20 & $0.014 *$ \\
Boys Intervention & 1.77 & 1,15 & 0.097 \\
Boys Control & 1.05 & 1,19 & 0.308 \\
\hline
\end{tabular}

$* \mathrm{p} \leq .06$ 
Table 51

Summary of Paired t-test Results for Stereotypic Occupational Scale (SOS) for You $\underline{\text { Neutral }}$

\begin{tabular}{llll}
\hline & T Value & DF & $\mathrm{p}$ \\
\hline Grade 2 & 0.80 & 1,37 & 0.431 \\
Grade 5 & 2.15 & 1,39 & $0.038^{*}$ \\
Boys & 0.10 & 1,35 & 0.920 \\
Girls & 3.44 & 1,41 & $0.001^{*}$ \\
Intervention & 3.15 & 1,37 & $0.003^{*}$ \\
Control & 0.23 & 1,39 & 0.822 \\
Intervention Grade 2 & 3.82 & 1,18 & $0.001^{*}$ \\
Intervention Grade 5 & 1.04 & 1,18 & 0.312 \\
Control Grade 2 & 1.61 & 1,18 & 0.125 \\
Control Grade 5 & 2.25 & 1,20 & $0.036^{*}$ \\
Girls Intervention & 3.25 & 1,21 & $0.004^{*}$ \\
Girls Control & 1.52 & 1,19 & 0.144 \\
Boys Grade 2 & 0.87 & 1,16 & 0.398 \\
Boys Grade 5 & 0.88 & 1,18 & 0.391 \\
Girls Grade 2 & 2.40 & 1,20 & $0.026^{*}$ \\
Girls Grade 5 & 2.52 & 1,20 & $0.020^{*}$ \\
Boys Intervention & 1.29 & 1,1 & 0.216 \\
Boys Control & 1.24 & 1,19 & 0.230 \\
\hline p s.06 & & & \\
\hline
\end{tabular}


Table 52

Summary of Paired t-test Results for Stereotypic Occupational Scale (SOS) for Man Masculine

\begin{tabular}{|c|c|c|c|}
\hline & $\mathrm{T}$ Value & $\mathrm{DF}$ & $\mathrm{p}$ \\
\hline Grade 2 & 2.89 & 1,37 & 0.787 \\
\hline Grade 5 & 1.17 & 1,40 & 0.248 \\
\hline Boys & 2.46 & 1,35 & 0.871 \\
\hline Girls & 1.42 & 1,42 & 0.162 \\
\hline Intervention & 0.74 & 1,38 & 0.464 \\
\hline Control & 0.77 & 1,39 & 0.448 \\
\hline Intervention Grade 2 & 0.81 & 1,18 & 0.427 \\
\hline Intervention Grade 5 & 1.89 & 1,19 & 0.074 \\
\hline Control Grade 2 & 1.92 & 1,18 & 0.071 \\
\hline Control Grade 5 & 0.65 & 1,20 & 0.524 \\
\hline Girls Intervention & 1.24 & 1,22 & 0.227 \\
\hline Girls Control & 0.72 & 1,19 & 0.478 \\
\hline Boys Grade 2 & 0.38 & 1,16 & 0.706 \\
\hline Boys Grade 5 & 0.66 & 1,18 & 0.516 \\
\hline Girls Grade 2 & 1.97 & 1,20 & 0.063 \\
\hline Girls Grade 5 & 0.62 & 1,21 & 0.540 \\
\hline Boys Intervention & 0.04 & 1,15 & 0.965 \\
\hline Boys Control & 0.29 & 1,19 & 0.772 \\
\hline
\end{tabular}


Table 53

Summary of Paired t-test Results for Stereotypic Occupational Scale (SOS) for Man Feminine

\begin{tabular}{llll}
\hline & T Value & DF & $\mathrm{p}$ \\
\hline Grade 2 & 0.20 & 1,37 & 0.840 \\
Grade 5 & 1.40 & 1,40 & 0.168 \\
Boys & 0.36 & 1,35 & 0.718 \\
Girls & 1.16 & 1,42 & 0.253 \\
Intervention & 1.78 & 1,38 & 0.082 \\
Control & 0.24 & 1,39 & 0.814 \\
Intervention Grade 2 & 1.75 & 1,18 & 0.097 \\
Intervention Grade 5 & 0.57 & 1,19 & 0.577 \\
Control Grade 2 & 1.90 & 1,18 & 0.073 \\
Control Grade 5 & 1.67 & 1,20 & 0.110 \\
Girls Intervention & 1.45 & 1,22 & 0.162 \\
Girls Control & 0.23 & 1,19 & 0.824 \\
Boys Grade 2 & 0.08 & 1,16 & 0.940 \\
Boys Grade 5 & 0.48 & 1,18 & 0.638 \\
Girls Grade 2 & 0.19 & 1,20 & 0.850 \\
Girls Grade 5 & 1.95 & 1,21 & 0.065 \\
Boys Intervention & 1.04 & 1,15 & 0.315 \\
Boys Control & 0.66 & 1,19 & 0.517 \\
\hline
\end{tabular}

$* \mathrm{p} \leq .06$ 
Table 54

Summary of Paired t-test Results for Stereotypic Occupational Scale (SOS) for Man Neutral

\begin{tabular}{llll}
\hline & $\mathrm{T}$ Value & $\mathrm{DF}$ & $\mathrm{p}$ \\
\hline Grade 2 & 1.32 & 1,37 & 0.196 \\
Grade 5 & 0.22 & 1,40 & 0.831 \\
Boys & 0.98 & 1,35 & 0.336 \\
Girls & 0.54 & 1,42 & 0.592 \\
Intervention & 0.05 & 1,38 & 0.961 \\
Control & 1.71 & 1,39 & 0.094 \\
Intervention Grade 2 & 1.75 & 1,18 & 0.098 \\
Intervention Grade 5 & 1.12 & 1,19 & 0.277 \\
Control Grade 2 & 3.46 & 1,18 & $0.003 *$ \\
Control Grade 5 & 1.67 & 1,20 & 0.110 \\
Girls Intervention & 0.01 & 1,32 & 1.000 \\
Girls Control & 0.79 & 1,19 & 0.439 \\
Boys Grade 2 & 1.23 & 1,16 & 0.236 \\
Boys Grade 5 & 0.13 & 1,18 & 0.897 \\
Girls Grade 2 & 0.56 & 1,20 & 0.584 \\
Girls Grade 5 & 0.18 & 1,21 & 0.860 \\
Boys Intervention & 0.06 & 1,15 & 0.952 \\
Boys Control & 1.55 & 1,19 & 0.138 \\
\hline
\end{tabular}

$* \mathrm{p} \leq .06$ 
Table 55

Summary of Paired t-test Results for Stereotypic Occupational Scale (SOS) for Woman Masculine

\begin{tabular}{llll}
\hline & T Value & DF & $\mathrm{p}$ \\
\hline Grade 2 & 2.89 & 1,37 & $0.006^{*}$ \\
Grade 5 & 1.32 & 1,40 & 0.195 \\
Boys & 2.46 & 1,35 & $0.019^{*}$ \\
Girls & 1.96 & 1,42 & $0.057^{*}$ \\
Intervention & 3.23 & 1,38 & $0.003^{*}$ \\
Control & 1.17 & 1,39 & 0.249 \\
Intervention Grade 2 & 3.89 & 1,18 & $0.001^{*}$ \\
Intervention Grade 5 & 0.55 & 1,19 & 0.587 \\
Control Grade 2 & 0.54 & 1,18 & 0.598 \\
Control Grade 5 & 1.25 & 1,20 & 0.226 \\
Girls Intervention & 2.56 & 1,22 & $0.018^{*}$ \\
Girls Control & 0.45 & 1,19 & 0.655 \\
Boys Grade 2 & 2.07 & 1,16 & $0.055^{*}$ \\
Boys Grade 5 & 1.38 & 1,18 & 0.186 \\
Girls Grade 2 & 1.97 & 1,20 & 0.063 \\
Girls Grade 5 & 0.62 & 1,21 & 0.540 \\
Boys Intervention & 1.97 & 1,15 & 0.067 \\
Boys Control & 1.47 & 1,19 & 0.158 \\
\hline
\end{tabular}

* $\mathrm{p} \leq .06$ 
Table 56

Summary of Paired t-test Results for Stereotypic Occupational Scale (SOS) for WomanFeminine

\begin{tabular}{llll}
\hline & T Value & DF & $\mathrm{p}$ \\
\hline Grade 2 & 0.88 & 1,37 & 0.385 \\
Grade 5 & 1.40 & 1,40 & 0.168 \\
Boys & 0.24 & 1,35 & 0.811 \\
Girls & 1.08 & 1,42 & 0.285 \\
Intervention & 0.85 & 1,38 & 0.403 \\
Control & 0.31 & 1,39 & 0.759 \\
Intervention Grade 2 & 1.02 & 1,18 & 0.322 \\
Intervention Grade 5 & 2.29 & 1,19 & $0.034 *$ \\
Control Grade 2 & 0.08 & 1,18 & 0.935 \\
Control Grade 5 & 0.32 & 1,20 & 0.751 \\
Girls Intervention & 0.78 & 1,22 & 0.445 \\
Girls Control & 0.74 & 1,19 & 0.470 \\
Boys Grade 2 & 1.44 & 1,16 & 0.168 \\
Boys Grade 5 & 1.02 & 1,18 & 0.320 \\
Girls Grade 2 & 0.53 & 1,20 & 0.599 \\
Girls Grade 5 & 0.94 & 1,21 & 0.360 \\
Boys Intervention & 0.48 & 1,15 & 0.639 \\
Boys Control & 1.18 & 1,19 & 0.253 \\
\hline
\end{tabular}

$* \mathrm{p} \leq .06$ 


\section{Table 57}

Summary of Paired t-test Results for Stereotypic Occupational Scale (SOS) for Woman Neutral

\begin{tabular}{llll}
\hline & T Value & DF & $\mathrm{p}$ \\
\hline Grade 2 & 0.39 & 1,37 & 0.701 \\
Grade 5 & 0.27 & 1,40 & 0.786 \\
Boys & 0.28 & 1,35 & 0.781 \\
Girls & 0.16 & 1,42 & 0.872 \\
Intervention & 0.44 & 1,38 & 0.661 \\
Control & 0.70 & 1,39 & 0.487 \\
Intervention Grade 2 & 0.58 & 1,18 & 0.567 \\
Intervention Grade 5 & 1.15 & 1,19 & 0.265 \\
Control Grade 2 & 0.08 & 1,18 & 0.935 \\
Control Grade 5 & 1.19 & 1,20 & 0.249 \\
Girls Intervention & 0.40 & 1,22 & 0.692 \\
Girls Control & 0.27 & 1,19 & 0.793 \\
Boys Grade 2 & 1.55 & 1,16 & 0.141 \\
Boys Grade 5 & 1.01 & 1,18 & 0.325 \\
Girls Grade 2 & 0.83 & 1,20 & 0.419 \\
Girls Grade 5 & 0.62 & 1,21 & 0.542 \\
Boys Intervention & 0.21 & 1,15 & 0.835 \\
Boys Control & 0.72 & 1,19 & 0.483 \\
\hline * s.06 & & & \\
\hline
\end{tabular}


Table 58

$\underline{\text { Summary of Paired t-test Results for CSRI - Masculine }}$

\begin{tabular}{llll}
\hline & $\mathrm{T}$ Value & $\mathrm{DF}$ & $\mathrm{p}$ \\
\hline Grade 2 & 0.01 & 1,37 & 1.000 \\
Grade 5 & 0.30 & 1,39 & 0.766 \\
Boys & 0.27 & 1,34 & 0.789 \\
Girls & 0.63 & 1,42 & 0.530 \\
Intervention & 0.47 & 1,37 & 0.639 \\
Control & 0.61 & 1,39 & 0.545 \\
Intervention Grade 2 & 0.17 & 1,18 & 0.866 \\
Intervention Grade 5 & 0.53 & 1,18 & 0.601 \\
Control Grade 2 & 0.13 & 1,18 & 0.899 \\
Control Grade 5 & 0.95 & 1,20 & 0.353 \\
Girls Intervention & 1.18 & 1,22 & 0.252 \\
Girls Control & 0.19 & 1,19 & 0.854 \\
Boys Grade 2 & 0.44 & 1,16 & 0.663 \\
Boys Grade 5 & 0.20 & 1,17 & 0.847 \\
Girls Grade 2 & 0.62 & 1,20 & 0.541 \\
Girls Grade 5 & 0.22 & 1,21 & 0.825 \\
Boys Intervention & 1.70 & 1,14 & 0.111 \\
Boys Control & 0.89 & 1,19 & 0.382 \\
\hline
\end{tabular}

$* \mathrm{p} \leq .06$ 
Table 59

Summary of Paired t-test Results for CSRI - Feminine

\begin{tabular}{llll}
\hline & $\mathrm{T}$ Value & $\mathrm{DF}$ & $\mathrm{p}$ \\
\hline Grade 2 & 0.13 & 1,37 & 0.896 \\
Grade 5 & 0.80 & 1,39 & 0.427 \\
Boys & 0.98 & 1,34 & 0.332 \\
Girls & 1.68 & 1,42 & 0.100 \\
Intervention & 0.71 & 1,37 & 0.484 \\
Control & 0.25 & 1,39 & 0.804 \\
Intervention Grade 2 & 0.17 & 1,18 & 0.866 \\
Intervention Grade 5 & 0.86 & 1,18 & 0.403 \\
Control Grade 2 & 0.40 & 1,18 & 0.695 \\
Control Grade 5 & 0.15 & 1,20 & 0.886 \\
Girls Intervention & 2.74 & 1,22 & 0.012 \\
Girls Control & 0.90 & 1,19 & 0.379 \\
Boys Grade 2 & 0.94 & 1,16 & 0.359 \\
Boys Grade 5 & 0.36 & 1,17 & 0.725 \\
Girls Grade 2 & 0.94 & 1,20 & 0.358 \\
Girls Grade 5 & 1.43 & 1,21 & 0.169 \\
Boys Intervention & 1.77 & 1,14 & 0.098 \\
Boys Control & 0.30 & 1,19 & 0.769 \\
\hline
\end{tabular}

$* \underline{\mathrm{p}} \leq .06$ 
Table 60

Summary of Paired t-test Results for Perceived Competence - Scholastic

\begin{tabular}{llll}
\hline & T Value & DF & $\mathrm{p}$ \\
\hline Grade 2 & 2.29 & 1,36 & $0.028^{*}$ \\
Grade 5 & 0.19 & 1,39 & 0.851 \\
Boys & 0.31 & 1,33 & 0.757 \\
Girls & 2.62 & 1,42 & $0.012^{*}$ \\
Intervention & 1.86 & 1,38 & 0.071 \\
Control & 0.92 & 1,37 & 0.365 \\
Intervention Grade 2 & 2.29 & 1,18 & $0.036^{*}$ \\
Intervention Grade 5 & 0.18 & 1,19 & 0.858 \\
Control Grade 2 & 1.01 & 1,17 & 0.326 \\
Control Grade 5 & 0.07 & 1,19 & 0.942 \\
Girls Intervention & 1.36 & 1,22 & 0.187 \\
Girls Control & 3.09 & 1,19 & $0.006^{*}$ \\
Boys Grade 2 & 0.36 & 1,15 & 0.721 \\
Boys Grade 5 & 0.01 & 1,17 & 1.000 \\
Girls Grade 2 & 3.28 & 1,20 & $0.004^{*}$ \\
Girls Grade 5 & 0.27 & 1,21 & 0.789 \\
Boys Intervention & 1.26 & 1,15 & 0.226 \\
Boys Control & 0.46 & 1,17 & 0.651 \\
\hline
\end{tabular}

* $\mathrm{p} \leq .06$ 
Table 61

Summary of Paired t-test Results for Perceived Competence - Social

\begin{tabular}{llll}
\hline & T Value & DF & $\mathrm{p}$ \\
\hline Grade 2 & 0.98 & 1,35 & 0.335 \\
Grade 5 & 2.02 & 1,39 & $0.050^{*}$ \\
Boys & 1.13 & 1,33 & 0.308 \\
Girls & 1.94 & 1,41 & $0.060^{*}$ \\
Intervention & 0.54 & 1,37 & 0.593 \\
Control & 2.44 & 1,37 & $0.020^{*}$ \\
Intervention Grade 2 & 0.34 & 1,17 & 0.742 \\
Intervention Grade 5 & 0.42 & 1,19 & 0.676 \\
Control Grade 2 & 1.05 & 1,17 & 0.311 \\
Control Grade 5 & 2.36 & 1,19 & $0.029^{*}$ \\
Girls Intervention & 0.35 & 1,21 & 0.727 \\
Girls Control & 2.38 & 1,19 & $0.028^{*}$ \\
Boys Grade 2 & 1.00 & 1,15 & 0.332 \\
Boys Grade 5 & 0.37 & 1,17 & 0.718 \\
Girls Grade 2 & 0.29 & 1,19 & 0.773 \\
Girls Grade 5 & 2.27 & 1,21 & $0.034^{*}$ \\
Boys Intervention & 0.40 & 1,15 & 0.695 \\
Boys Control & 1.04 & 1,17 & 0.313 \\
\hline
\end{tabular}

$* \mathrm{p} \leq .06$ 
Table 62

Summary of Paired t-test Results for Perceived Competence - Athletic

\begin{tabular}{llll}
\hline & T Value & DF & $\mathrm{p}$ \\
\hline Grade 2 & 1.43 & 1,37 & 0.161 \\
Grade 5 & 1.61 & 1,38 & 0.115 \\
Boys & 1.13 & 1,34 & 0.265 \\
Girls & 1.80 & 1,41 & 0.079 \\
Intervention & 2.39 & 1,37 & $0.022 *$ \\
Control & 0.82 & 1,38 & 0.420 \\
Intervention Grade 2 & 2.72 & 1,18 & $0.014 *$ \\
Intervention Grade 5 & 0.71 & 1,18 & 0.486 \\
Control Grade 2 & 0.08 & 1,18 & 0.940 \\
Control Grade 5 & 1.61 & 1,19 & 0.124 \\
Girls Intervention & 1.73 & 1,21 & 0.099 \\
Girls Control & 0.84 & 1,19 & 0.409 \\
Boys Grade 2 & 0.43 & 1,16 & 0.671 \\
Boys Grade 5 & 1.29 & 1,17 & 0.213 \\
Girls Grade 2 & 1.52 & 1,20 & 0.144 \\
Girls Grade 5 & 0.95 & 1,20 & 0.354 \\
Boys Intervention & 1.63 & 1,15 & 0.123 \\
Boys Control & 0.32 & 1,18 & 0.753 \\
\hline
\end{tabular}

* $\underline{p} \leq .06$ 
Table 63

Summary of Paired t-test Results for Perceived Competence - Physical

\begin{tabular}{llll}
\hline & T Value & DF & $\mathrm{p}$ \\
\hline Grade 2 & 1.76 & 1,35 & 0.088 \\
Grade 5 & 1.84 & 1,37 & 0.073 \\
Boys & 1.62 & 1,32 & 0.116 \\
Girls & 2.00 & 1,40 & $0.053^{*}$ \\
Intervention & 1.33 & 1,36 & 0.193 \\
Control & 2.30 & 1,36 & $0.028^{*}$ \\
Intervention Grade 2 & 1.82 & 1,18 & 0.073 \\
Intervention Grade 5 & 1.25 & 1,18 & 0.227 \\
Control Grade 2 & 2.01 & 1,17 & 0.610 \\
Control Grade 5 & 1.32 & 1,18 & 0.203 \\
Girls Intervention & 0.66 & 1,21 & 0.514 \\
Girls Control & 2.53 & 1,18 & $0.021^{*}$ \\
Boys Grade 2 & 0.54 & 1,14 & 0.597 \\
Boys Grade 5 & 1.64 & 1,17 & 0.119 \\
Girls Grade 2 & 1.90 & 1,20 & 0.072 \\
Girls Grade 5 & 0.90 & 1,20 & 0.592 \\
Boys Intervention & 1.26 & 1,14 & 0.227 \\
Boys Control & 1.03 & 1,17 & 0.316 \\
\hline
\end{tabular}

$* \mathrm{p} \leq .06$ 
Table 64

$\underline{\text { Summary of Paired t-test Results for Perceived Competence - Behavioral }}$

\begin{tabular}{llll}
\hline & $\mathrm{T}$ Value & $\mathrm{DF}$ & $\mathrm{p}$ \\
\hline Grade 2 & 0.34 & 1,36 & 0.733 \\
Grade 5 & 0.09 & 1,37 & 0.931 \\
Boys & 1.16 & 1,32 & 0.256 \\
Girls & 0.54 & 1,41 & 0.591 \\
Intervention & 2.88 & 1,36 & $0.007^{*}$ \\
Control & 2.08 & 1,37 & $0.045^{*}$ \\
Intervention Grade 2 & 0.34 & 1,18 & 0.733 \\
Intervention Grade 5 & 1.63 & 1,17 & 0.121 \\
Control Grade 2 & 1.23 & 1,17 & 0.235 \\
Control Grade 5 & 2.30 & 1,19 & $0.033^{*}$ \\
Girls Intervention & 1.83 & 1,21 & 0.081 \\
Girls Control & 2.44 & 1,19 & $0.025^{*}$ \\
Boys Grade 2 & 0.88 & 1,15 & 0.391 \\
Boys Grade 5 & 0.72 & 1,16 & 0.482 \\
Girls Grade 2 & 0.25 & 1,20 & 0.803 \\
Girls Grade 5 & 0.63 & 1,20 & 0.534 \\
Boys Intervention & 2.22 & 1,14 & $0.043^{*}$ \\
Boys Control & 0.43 & 1,17 & 0.676 \\
\hline
\end{tabular}

$* \mathrm{p} \leq .06$ 
Table 65

Summary of Paired t-test Results for Perceived Competence - Global

\begin{tabular}{llll}
\hline & $\mathrm{T}$ Value & $\mathrm{DF}$ & $\mathrm{p}$ \\
\hline Grade 2 & 1.70 & 1,35 & $0.098^{*}$ \\
Grade 5 & 1.01 & 1,39 & 0.321 \\
Boys & 1.07 & 1,33 & 0.293 \\
Girls & 1.60 & 1,41 & 0.116 \\
Intervention & 0.18 & 1,37 & 0.860 \\
Control & 2.67 & 1,37 & $0.011^{*}$ \\
Intervention Grade 2 & 1.60 & 1,18 & 0.116 \\
Intervention Grade 5 & 0.05 & 1,18 & 0.958 \\
Control Grade 2 & 2.66 & 1,16 & $0.017^{*}$ \\
Control Grade 5 & 1.20 & 1,20 & 0.245 \\
Girls Intervention & 0.41 & 1,21 & 0.688 \\
Girls Control & 2.43 & 1,19 & $0.025^{*}$ \\
Boys Grade 2 & 0.59 & 1,14 & 0.565 \\
Boys Grade 5 & 0.88 & 1,18 & 0.392 \\
Girls Grade 2 & 1.62 & 1,20 & 0.122 \\
Girls Grade 5 & 0.54 & 1,20 & 0.592 \\
Boys Intervention & 0.22 & 1,15 & 0.826 \\
Boys Control & 1.21 & 1,17 & 0.242 \\
\hline
\end{tabular}

$* \mathrm{p} \leq .06$ 
Bibliography

Alpert-Gillis, L. J., \& Connell, J. P. (1989). Gender and sex-role influences on children's self esteem. Journal of Personality, 57, 97-114.

The AAUW Report. American Association of University Women (1992). How schools short change girls. Washington, DC.

American Psychological Association (1983). Publication Manual of the American Psychological Association (3rd ed.). Washington, DC: Author.

Absi-Semaan, N., Crombie, G., \& Freeman, C. (1993). Masculinity and femininity in middle childhood: Developmental and factor analyses. Sex Roles, $\underline{28}, 187-206$.

Bailey, B. A., \& Nihlen, A. S. (1988). Children's display of gender schemas through interaction with nontraditional workers. Anthropology and Education Quarterly, 19, 155-162.

Bailey, B. A., \& Nihlen, A. S. (1990). Effect of experience with nontraditional workers on psychological and social dimensions of occupational sex-role stereotyping by elementary school children. Psychological Reports, $\underline{66}, 1273-1282$.

Bandura, A. (1977). Social Learning Theory. Englewood Cliff, NJ: Prentice-Hall.

Bandura, A., \& Walters, R. (1963). Social learning and personality development. New York: Holt, Rinehart and Winston.

Bem, S. L. (1974). The measurement of psychological androgyny. Journal of Consulting and Clinical Psychology, 42, 155-162.

Bem, S. L. (1975). Sex role adaptability: Once consequence of psychological androgyny. Journal of Personality and Social Psychology, 31, 634-643.

Bem, S. L. (1977). On the utility of alternative procedures for assessing psychological androgyny. Journal of Consulting and Clinical Psychology, 45, 196-205.

Bem, S. L. (1979). The theory and measurement of androgyny: A reply to the Pedhauzer-Tetenbaum and Locksley-Colten critiques. Journal of Personality and Social Psychology, 37, 1047-1054.

Bem, S. L. (1981a). Gender schema theory: A cognitive account of sex typing. Psychological Review, $\underline{88}, 354-364$. 
Bem, S. L. (1981b). The BSRI and gender schema theory: A reply to Spence and Helmreich. Psychological Review, 88, 369-371.

Bem, S. L. (1983). Gender schema theory and its implications for child development: Raising gender-aschematic children in a gender-schematic society. Signs: Journal of Women in Culture and Society, $\underline{8}, 598-616$.

Bem, S. L. (1984). Androgyny and gender schema theory: A conceptual and empirical integration. In T. B. Sonderegger (Ed.), Nebraska Symposium on Motivation, Psychology and gender (pp. 179-226). Lincoln: University of Nebraska Press.

Bem, S. L. (1987). Gender schema theory and the romantic tradition. In P. Shaver \& C. Hendricks (Eds.), Review of Personality and Social Psychology (Vol. 7, pp. 251271. Newbury Park, CA: Sage.

Bem, S. L. (1992). On the inadequacy of our sexual categories: A personal perspective. Feminism and psychology, 2, 435-437.

Bem, S. L. (1993a). Is there a place in psychology for a feminist analysis of the social context? Feminism \& Psychology, $\underline{3}, 230-234$.

Bem, S. L. (1993b). The lenses of gender: Transforming the debate on sexual inequality. New Haven: Yale University Press.

Bem, S. L., \& Lenney, E. (1976). Sex-typing and the avoidance of cross-sex behavior. Journal of Personality and Social Psychology, 33, 48-54.

Bigler, R. S., \& Liben, L. S. (1990). The role attitudes and interventions in gender schematic processing. Child Development, 61, 1440-1452.

Bigler, R. S., \& Liben, L. S. (1992). Cognitive mechanisms in children's gender stereotyping: Theoretical and educational implications of a cognitive-based intervention. Child Development, 63, 1351-1363.

Bliss, S. B. (1988). The effect of feminist attitudes in parents on their kindergarten children. Smith College Studies in Social Work, 58, 182-192.

Bohan, J. S. (1993). Regarding gender: Essentialism, constructionism, and feminist psychology. Psychology of Women Quarterly, 17, 5-21.

Boldizar, J. P. (1991). Assessing sex typing and androgyny in children: The children's sex role inventory. Developmental Psychology, 27, 505-515. 
Brown, J. M., \& Gilligan, C. (1993). Meeting at the crossroads: Women's psychology and girls' development. Feminism \& Psychology, 3 , 11-35.

Bussey, K., \& Bandura, A. (1984). Influence of gender constancy and social power on sex linked modeling. Journal of Personality and Social Psychology, 47, 1292-1302.

Calvert, S., \& Huston, A. (1987). Television and children's gender schemata. New Directions for Child Development, $\underline{38}, 75-88$.

Campbell, D. T., \& Stanley, J. C. (1963). Experimental and Quasi-Experimental Designs for Research. Boston: Houghton Mifflin.

Cohen, J. (1992). You can be a woman engineer. Culver City, CA: Cascade Pass.

Constantinople, A. (1973). Masculinity - femininity: An exception to the famous dictum. Psychological Bulletin, $\underline{80}, 389-407$.

Coopersmith, S. (1967). The Antecedents of Self-Esteem. San Francisco: W. H. Freeman.

Deaux, K., Kite, M. E., \& Lewis, L. L. (1985). Clustering and gender schemata: An uncertain link. Personality and Social Psychology Bulletin, 11, 387-397.

Downs, A. C., \& Langlois, J. H. (1988). Sex-typing: Construct and measurement issues.

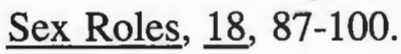

Eagly, A. H. (1987). Sex Differences in Social Behavior: A Social-Role Interpretation. Hillsdale, NJ: Lawrence Erlbaum.

Eagly, A. H., \& Wood, W. (1982). Inferred sex differences in status as a determinant of gender stereotypes about social influence. Journal of Personality and Social Psychology, 43, 915-928.

Eisenberg, N., Wolchik, S. A., Hernandez, R., \& Pasternack, J. F. (1985). Parental socialization of young children's play: A short-term longitudinal study. Child Development, $\underline{56}, 1506-1513$.

Elliott, S.N., Witt, J.C., Kratochwill, T.R. (1991). Selecting, implementing, and evaluating classroom interventions. In G. Stoner, M.R. Shinn, H.M. Walker (Eds.), Intervention for achievement and behavior problems, Silver Springs, MD: National Association for School Psychologist.

Epstein, V. (1980). The ABC's of what a girl can be. Denver; CO: VSE Publisher. 
Erikson, E. H. (1950). Children and society. New York: Norton.

Fagot, B. I. (1985a). A cautionary note: Parents' socialization of boys and girls. Sex Roles, 12 , 471-476.

Fagot, B. I. (1985b). Beyond the reinforcement principle: Another step toward understanding sex role development. Developmental Psychology, 21, 1097-1104.

Frey, K. S., \& Ruble, D. N. (1992). Gender constancy and the "cost" of sex-typed behavior: A test of the conflict hypothesis. Developmental Psychology, 28, 714-721.

Hall, J. A., \& Halberstadt, A. G. (1980). Masculinity and femininity in children: Development of the children's personal attributes questionnaire. Developmental Psychology, 16, 270-280.

Harter, S. (1982). The perceived competence scale for children. Child Development, $\underline{53}, 87-97$.

Harter, S. (1983). Developmental perspectives on the self-system. In E. M. Hetherington (Ed.), Handbook of child psychology (Vol. 4): Socialization, personality, and social development. New York: Wiley.

Harter, S. (1984). Competence as a dimension of self-evaluation: Toward a comprehensive model of self-worth. In R. Leahy (Ed.), The development of the self. New York: Academic Press.

Harter, S. (1985a). Assessment of perceived competence, motivational orientation, and anxiety in segregated and mainstreamed educable mentally retarded children. Journal of Educational Psychology, 77, 217-230.

Harter, S. (1986). Processes underlying the construction, maintenance, and enhancement of the self-concept in children. In J. Suls \& A. G. Greenwald (Eds.), Psychological perspectives on the self (Vol. 3, pp. 139-181). Hillsdale, NJ: Erlbaum.

Harter, S. (1987). The determinants and functional role of self-worth. In N. Eisenberg (Ed.), Contemporary topics in Developmental Psychology. New York: Wiley.

Harter, S. (1988a). The construction and conservation of the self: James and Cooley revisited. In D. K. Lapsley \& F. C. Bower (Eds.). Self, ego, and identity: Integrative approaches. New York: Springer-Verlag.

Harter, S. (1988b). Causes, correlates and the functional role of global self-worth: A life-span perspective. In J. Kolligan \& R. Sternberg (Eds.). Perceptions of 
competence and incompetence across the life-span. New Haven, CT: Yale University Press.

Harter, S. (1988). Developmental processes in the construction of the self. In T. D. Yawkey \& J. E. Johnson (Eds.), Integrative processes and socialization: Early to middle childhood (pp. 45-78). Hillsdale, NJ: Erlbaum.

Harter, S. (1990). Assessing children's self-concept. In A. LaGreca (Ed.), Child Assessment. Newton, MA: Allyn \& Bacon.

Harter, S. (1990). Causes, correlated, and the functional role of global self-worth: A lifespan perspective. In R. Sternberg \& J. Kollgian, Jr. (Eds.), Competence considered (pp. 67-97). New Haven, CT: Yale University Press.

Harter, S., \& Pike, R. (1984). The pictorial scale of perceived competence and social acceptance for young children. Child Development, 55, 1962-1982.

Hattie, J. (1992). Self-Concept. Hillsdale, NJ: Lawrence Erlbaum.

Helmreich, R. L., Spence, J. T., \& Holahan, C. K. (1979). Psychological androgyny and sex role flexibility: A test of two hypotheses. Journal of Personality and Social Psychology, 37, 1631-1644.

Howard, G. S. (1991). Culture tales: A narrative approach to thinking, cross-cultural psychology, and psychotherapy. American Psychologist, 46, 187-197.

Hudak, M. A. (1993). Gender schema theory revisited: men's stereotypes of American women. Sex Roles, $\underline{28}, 279-293$.

Hughes, C. M., Martinek, S. A., \& Fitzgerald, L. F. (1985). Sex role attitudes and career choices. Elementary School Guidance and Counseling, 20, 57-66.

Huston, A. C. (1983). Sex-typing. In P. H. Mussen Handbook of Child Psychology (Vol. 4, pp. 387-467), New York: Wiley.

Jacklin, C. N. (1989). Male and female: Issues of gender. American Psychologist, 44 , 127-133.

Keppel, G. (1982). Design analysis: A researcher's handbook. Englewood Cliffs, NJ: Prentice-Hall.

Klein, H. A. (1992). Individual temperament and emerging self-perception: An interactive perspective. Journal of Research in Childhood Education, 6, 113-120. 
Kohlberg, L. (1966). A cognitive-developmental analysis of children's sex-role concepts and attitudes. In E. E. Maccoby (Ed.), The Development of Sex Differences (pp. 82172). Stanford, CA: Stanford University Press.

Lamke, L. K. (1982). The impact of sex-role orientation on self-esteem in early adolescence. Child Development, 53, 1530-1535.

Leahy, R. L., \& Shirk, S. R. (1984). The development of classificatory skills and sextrait stereotypes in children. Sex Roles, 10, 281-292.

Levy, G. D., \& Carter, D. B. (1989). Gender schema, gender constancy, and genderrole knowledge: The role of cognitive factors in preschooler's gender-role stereotype attributions. Developmental Psychology, 25, 444-449.

Lenkowsky, R. S. (1987). Bibliotherapy: A review and analysis of the literature. The Journal of Special Education, 21, 123-130.

Liben, L., \& Bigler, R. (1987). Reformulating children's gender schemata. New Directions for Child Development, $\underline{38}$, 89-105.

Liben, L. S., \& Signorella, M. L. (1980). Gender related schemata and constructive memory in children. Child Development, 51, 11-18.

Liben, L., \& Signorella, M. (1993). Gender schematic processing in children: The role of initial interpretation of stimuli. Developmental Psychology, 29, 141-149.

Lipka, R. P., \& Brinthaupt, T. M. (1992). Self-perspectives across the life span. Albany; (NY): State University of New York Press.

Lott, A. J., \& Lott, B. E. (1968). A learning theory approach to interpersonal attitudes. In A. G. Greenwald, T. C. Brock, \& T, M. Omstrom (Eds.), Psychological foundations of attitudes (pp. 67-88). NY: Academic Press.

Lott, B. (1981). A feminist critique of androgyny: Toward the elimination of gender attributions for learned behavior. In C. Mayo \& N. M. Henely (Eds.), Gender and nonverbal behavior (pp. 171-180). NY: Springer-Verlag.

Lott, B. (1985). The potential enrichment of social/personality psychology through feminist research and vice versa. American Psychologist, 40, 155-164.

Lott, B. (1988). Separate spheres revisited. Contemporary Social Psychology, 13, 5562. 
Lott, B. (1990). Dual natures or learned behavior: The challenge to feminist psychology. In R. T. Hare-Mustin \& J. Marecek (Eds.), Making a Difference: Psychology and the Construction of Gender (pp. 65-101). New Haven, CT: Yale University Press.

Lott, B. (1993). Women' lives: Themes and variations in gender learning (2nd ed.). CA: Pacific Grove, Brooks/Cole Publishing.

Lott, B., \& Lott, A. J. (1985). Learning theory in contemporary social psychology. In G. Lindzey \& E. Aaronson (Eds.), Handbook of Social Psychology (3rd ed.). (Vol. 1, pp. 109-135). NY: Random House.

Lott, B., \& Maluso, D. (1993). The social learning of gender. In A. E. Beall, \& R. J. Sternberg (Eds.) The psychology of gender (pp. 99-123). New York: Guilford Press.

Maccoby, E. E. (1990). The role of gender identity and gender constancy in sexdifferentiated development. New Directions for Child Development, 47, 5-28.

Marsh, J. W., \& Gouvernet, P. J. (1989). Multidimensional self-concepts and perceptions of control: Construct validation of responses by children. Journal of Educational Psychology, 81, 57-69.

Martin, C. L., \& Halverson, C. F. (1983). The effects of sex-typing schemas on young children's memory. Child Development, $\underline{54}$, 563-574.

Martin, C. L., Wood, C. H., \& Little, J. K. (1990). The development of gender stereotype components. Child Development, 61, 1891-1904.

Meece, J. (1987). The influence of school experiences on the development of gender schemata. New Directions for Child Development, 38, 57-74.

Mischel, W. (1970). Sex-typing and socialization. In P. H. Mussen (Ed.), Carmichaels' Manual of Child Psychology, 2, pp. 3-72, New York: Wiley.

Mussen, P. H. (1969). Early sex-role development. In D. A. Goslin (Ed.), Handbook of socialization theory and research (pp. 707-732). Chicago: Rand-McNally.

Nastasi, B. E., \& DeZolt, D. M. (1994). School interventions for children of alcoholics. NY: Guilford.

Nihlen, A. S., \& Bailey, B. A. (1988). Children's display of gender schemas through interaction with nontraditional workers. Anthropology and Education Quarterly, 19, 155-162. 
Orlofsky, J. L., \& O'Heron, C. A. (1987). Stereotypic and non-stereotypic sex role trait and behavior orientations, Journal of Personality and Social Psychology, 52, 10341042.

Pedhauzur, E. J., \& Tetenbaum, T. J. (1979). The Bem Sex Role Inventory: A theoretical and methodological critique. Journal of Personality and Social Psychology, 37, 996-1016.

Piaget, J. (1970). Piaget's theory. In P. H. Mussen (Ed.), Carmichaels' Manual of Child Psychology (Vol. 1, pp. 703-732). New York: Wiley.

Piers, E., \& Harris, D. (1969). The Piers-Harris Children's Self-Concept Scale. Nashville, TN: Counselor Recordings and Tests.

Pietromonaco, P. R., Manis, J., \& Frohardt-Lane, K. (1986). Psychological consequences of multiple social roles. Psychology of Women Quarterly, 10, 373382.

Schank, R. C. (1990). Tell me a story: A new look at real and artificial memory. New York: Charles Scribner's Sons.

Serbin, L. A., \& Sprafkin, C. (1986). The salience of gender and the process of sex typing in three-to seven-year-old children. Child Development, 57, 1188-1199.

Signorella, M. (1987). Gender schemata: Individual difference and context effects. New Directions for Child Development, 38, 23-38.

Silon, E. L., \& Harter, S. (1985). Assessment of perceived competence, motivational orientation, and anxiety in segregated and mainstreamed educable mentally retarded children. Journal of Educational Psychology, 77, 217-230.

Slaby, R. G. (1990). The gender concept development legacy. New Directions for Child Development, 47, 21-29.

Spence, J. T. (1985). Gender identity and its implications for the concepts of masculinity and femininity. In T. B. Sonderegger (Ed.). Nebraska symposium on motivation, 1984: Psychology and gender (Vol. 32) (pp. 59-96). Lincoln, NE: University of Nebraska Press.

Spence, J. T., \& Helmreich, R. L. (1978). Masculinity and femininity: Their psychological dimensions, correlates, and antecedents. Austin: University of Texas Press. 
Stangor, C., \& McMillan, . (1992). Memory for expectancy-congruent and expectancy incongruent information: A review of the social and social developmental literatures.

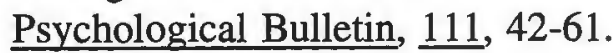

Stangor, C., \& Ruble, D. (1987). Development of gender role knowledge and gender constancy. New Directions for Child Development, $\underline{38}, 5-22$.

Stigler, J. W., Smith, S., \& Mao, L. (1985). The self-perception of competence by Chinese children. Child Development, 56, 1259-1270.

Stonewater, B. B., Eveslage, S. A., \& Dingerson, M. R. (1990). Gender difference in career helping relationships. The Career Development Quarterly, 39, 72-85.

Tabachnick, B. G., \& Fidell, L. S. (1983). Using Multivariate Statistics. NY: Harper \& Row.

Tanaka, J. W., \& Westerman, M. A. (1988). Common dimensions in the assessment of competence in school-aged girls. Journal of Educational Psychology, $\underline{80}, 579-584$.

Tappan, M. B. (1989). Stories lived and stories told: The narrative structure of late adolescent moral development. Human Development, $\underline{32}$, 300-315.

Tappan, M. B., \& Brown, L. M. (1989). Stories told and lessons learned: Toward a narrative approach to moral development and moral education. Harvard Educational Review, 59, 182-205.

Taylor, M. S., \& Hall, J. A. (1982). Psychological androgyny: Theories methods, and conclusions. Psychological Bulletin, 92, 347-366.

Thomas, R. M. (1985). Comparing Theories of Child Development - (2nd Ed.). Belmont, CA: Wadsworth.

Tozzo, S. G., \& Golub, S. (1990). Playing nurse and playing cop: Do they change children's perceptions of sex-role stereotypes? Journal of Research in Childhood Education, 4, 123-129.

Unger, R., \& Crawford, M. (1992). Women and Gender: A Feminist Psychology. Philadelphia: Temple University Press.

U. S. Bureau of the Census. (1991). Statistical Abstracts of the United States. Washington DC: U. S. Government Printing Office.

Whitley, B. E., Jr. (1985). Sex-role orientation and psychological well-being: Two meta-analyses. Sex Roles, 12, 207-225. 
Wilson, F. R. (1984). Construct validity of four androgyny instruments. Sex Roles, $\underline{11}$, 813-837.

Wong, F. Y., McCreary, D. R. \& Duffy, K. G. (1990). A further validation of the Bem Sex Role Inventory: A multitrait-multimethod study. Sex Roles, 22, 249-259.

Wright, J. W., \& Dwyer, E. J. (1990). The American Almanac of Jobs and Salaries: NY: Avon Books.

Wylie, R. C. (1989). Measures of self-concept. Lincoln,NE:University of Nebraska Press.

Whitley, B. E. (1983). Sex role orientation and self esteem: A critical meta-analytic review. Journal of Personality and Social Psychology, 44, 765-778. 